\title{
FREQUENCY AND SUCCESS: AN EMPIRICAL STUDY OF CRIMINAL LAW DEFENSES, FEDERAL CONSTITUTIONAL EVIDENTIARY CLAIMS, AND PLEA NEGOTIATIONS
}

\author{
STEPHEN G. VALDES ${ }^{\dagger}$
}

\section{INTRODUCTION}

Discussions of criminal law defenses typically focus on policy issues, ' with pundits, lawmakers, and scholars each advocating different grounds for allowing various defenses. While the insanity defense and plea negotiations have been the subject of intense philosophical and statistical scrutiny, most defenses have simply been accepted as part of the system without any empirical examination of their use. ${ }^{2}$ This survey of prosecutors, judges, and defense attorneys investigates the frequency and success rates of six defenses (entrapment, statutes of limitations, double jeopardy, diplomatic immunity, insanity, and reasonable mistake of law), three constitutional evidentiary provisions (the Fourth Amendment search and seizure exclusionary rule, the Fifth Amendment Miranda rule, and Sixth Amendment faulty identification procedures), and plea negotiations.

\footnotetext{
${ }^{\dagger}$ B.A. 2000, University of Notre Dame; J.D. Candidate 2005, University of Pennsylvania. This paper is dedicated to my mother for always being there to support me. This project would have not been possible without the support of Professor Paul Robinson, who assisted with and funded the survey and to whom I am extremely grateful. Many thanks are due to Sarah Greenberger, Nell McCarthy, and Sean McEldowney at the Penn Law Review who did outstanding work editing the piece and providing critique. Thanks as well to Professor David Rudovsky for advice in designing the survey, Professor Seth Kreimer for providing feedback on the paper, and Frank Yoon for assistance reviewing the research methods used in this study. Finally, to my friends whom I pressed into service at various stages of the project, I owe a great deal of thanks: Matthew Insley-Pruitt, Jennifer E. Lee, Nicholas Murat, Atul Aggarwal, Sheela Pai, Melissa Grouzard, Loren Stewart, Jina Chung, Victoria Anderson, Alastair Agcaoili, Alex Sistla, and Emily Cohen.

See Neil P. Cohen et al., The Prevalence and Use of Criminal Defenses: A Preliminary Study, 60 TENN. L. REV. 957, 957 (1993) (“[V]irtually all of the literature on criminal defenses focuses on either doctrinal or strategic issues. ... Unfortunately, very little has been written about the actual use of criminal defenses in the American criminal justice system.”).

${ }^{2}$ See $i d$. (stating that insanity is the only defense that has received significant attention).
} 
This survey is unique in its attempt to go beyond the trial setting (where most previous studies have focused) ${ }^{3}$ to understand the use and application of defenses in the criminal justice system as a whole. Because only about five percent of criminal cases are decided at trial, ${ }^{4}$ existing trial-focused surveys fail to paint an accurate picture of the true role of defenses. To reach beyond the confines of trial transcripts and limited resources, this survey asked individual prosecutors, judges, and defense attorneys to answer questions based on all the cases they saw in the past twelve months, rather than just those that went to trial. ${ }^{5}$ Respondents estimated the number of times they encountered each defense, how often it was successful, how often it could have been offered but was not, and how often it resulted in nonprosecution of a case. ${ }^{6}$

Part I of this Comment describes the research methods used in the study. Parts II through IV provide background information on the defenses being studied and present the study's results regarding the use and success of these defenses. Specifically, Part II centers on the criminal defenses; Part III addresses the Fourth, Fifth, and Sixth Amendment exclusionary rules; and Part IV discusses plea negotiations. Finally, Part V reviews items not specifically covered under the previous sections: the difference in the results between Maryland district court and Maryland circuit court and the effect of plea negotiations on the application of the defenses. The Comment concludes with a brief discussion of what the results of this survey suggest for future study in these areas.

\section{RESEARCH METHODS}

A cover letter giving background on the purpose of the study, a copy of the survey, and a business reply envelope were mailed to 914 judges, 983 prosecuting attorneys, and 912 criminal defense attorneys in Arkansas, Colorado, Maryland, Rhode Island, Oregon, and Wiscon-

\footnotetext{
${ }^{3}$ See, e.g., id. at 960-81 (surveying trial usage of various defenses); Peter F. Nardulli, The Societal Cost of the Exclusionary Rule: An Empirical Assessment, 1983 AM. B. Found. RES. J. 585, 593 (basing results on trial court files).

Jenny Roberts, Too Little, Too Late: Ineffective Assistance of Counsel, the Duty to Investigate, and Pretrial Discovery in Criminal Cases, 31 FORDHAM URB. L.J. 1097, 1136 (2004) ("About ninety-five percent of criminal cases end not with trials, but in plea bargains.”).

${ }^{5}$ The survey questionnaire used in this study is included in Appendix A, infra. All survey questionnaire responses are on file with the author.

${ }^{6}$ Infra app. A.
} 
$\sin ;{ }^{7} 400$ surveys were returned, 148 by state court judges, ${ }^{8} 128$ by prosecutors, and 124 by defense attorneys. ${ }^{9}$

The survey first asked the respondents to indicate their position ("Judge," "Prosecutor," or "Defense Attorney"), their location ("Urban," "Suburban," or "Rural"), the number of criminal cases in which they were personally involved during the past twelve months, and the number of criminal cases in their locale over the past twelve months. ${ }^{10}$ For each defense, the survey asked the respondent to estimate the number of cases in the past twelve months in which each defense was raised, ${ }^{11}$ was successful, could have been raised but was not, or was the grounds for nonprosecution of the defendant. ${ }^{12}$ Regarding plea bargains, respondents were asked to estimate the percentage, rather than number, of cases in which a plea bargain was offered; the percentage of plea offers that were accepted; and the percentage of accepted plea bargains that resulted in a reduced charge, a reduced sentence, or in

${ }^{7}$ In entering the results, three methods were adopted to standardize entries. Each of these was necessary to prevent otherwise acceptable responses from being discarded. The three main techniques were: (1) if a respondent answered with a range, the middle point was entered as her response (e.g., if a respondent answered "7-10," "8.5" was used as her answer); (2) if a respondent answered "0" for "Defense Offered" but left "Defense Successful" blank, "0" was entered for "Defense Successful"; (3) if a respondent used percentages, the actual number was calculated from the percent and the respondent's number of cases (e.g., if respondent heard 100 cases and answered " $1 \%$ " to a particular question, then "1" was entered as her response).

${ }^{8}$ Of the 148 state court judge responses, 13 were from Maryland district court judges and are not included in the overall results. See infra note 21 and accompanying text.

${ }^{9}$ Respondents saw a combined total of 188,031 criminal cases themselves, and estimated a combined total of 1,991,607 criminal cases in their various locales. Felony court judges saw an average of 641 criminal cases per year, prosecutors 640 , and defense attorneys 145. It is possible that there was some overlap between cases seen by judges, prosecutors, and defense attorneys, but there is no way to ascertain the extent of such overlap.

${ }^{10}$ In the first round of surveys, the adjective "criminal" was mistakenly omitted before the word "cases"; follow-up was conducted on completed surveys from that batch to prevent mixing of criminal and civil case loads. Because terminology varies from state to state, the more general term "locale" was chosen instead of terms such as "district" or "ward." A small number of surveys were mailed out using the term "district" rather than "locale." Because of the small number, it was not possible to ascertain whether this difference in wording affected the results reported for "locale."

${ }^{11}$ Surveys containing the phrase "at trial" in the question description were mistakenly sent out to a portion of those surveyed. Comparing this sample with results from those receiving the correct survey showed no statistical difference in responses received.

${ }^{12}$ This method was adapted from that used in the Cohen study. Cohen et al., supra note 1, at 959. Special thanks to Professor Cohen for speaking with me about the method and offering suggestions for use in my study. 
nonprosecution. ${ }^{13}$ Finally, a page was left open for free responses, and respondents were given the option of providing contact information. ${ }^{14}$ Since the majority of the defenses studied are rarely used, by limiting the time frame to the previous twelve months my intention was that respondents would remember the defenses' occurrences and be able to provide accurate information as to how many times respondents personally saw the defenses. Anecdotal evidence supporting this assertion was offered by some respondents who commented that they remembered seeing certain defenses a specific number of times in their career, let alone in the past twelve months. ${ }^{15}$

In some cases, a judge saw only a handful of criminal cases in the past twelve months, while others saw a great deal. This is because some judges split their dockets between criminal and civil cases, while others primarily focus on one or the other. Similarly, prosecutors and defense attorneys may handle either felony or misdemeanor cases. As such, those surveyed represent a variety of different case loads and potential specializations within criminal law. The individual circumstances of each respondent naturally shape the types of cases she encounters and therefore the likelihood of certain defenses being raised in the cases she sees. ${ }^{16}$ Additionally, the study sought to survey every judge and prosecutor and a large number of defense attorneys in each jurisdiction. Because of this, it is possible that respondents share some characteristic that might affect the results. It is impossible to ascertain if there is a bias and how such a bias might have impacted the data. However, respondents' answers to the question on plea bargains, which have been studied in depth elsewhere, match the num-

${ }^{13}$ The survey assumed a plea has three possible outcomes: the original charge is reduced, the charge remains the same but the defendant receives a reduced sentence, or the prosecution is dropped either completely or contingent on some other condition. There was a significant overlap between these categories, which is discussed in greater detail infra text accompanying notes 139-41.

${ }^{14}$ Each survey had a confidential identification number to allow for tracking responses, though the number was removed by a few respondents. In order to protect the confidentiality of the respondents, each respondent was assigned another random number that differed from the number affixed to that person's survey itself. Respondents quoted in this Comment are identified by this random number to further protect anonymity.

${ }^{15}$ Respondents 55,789 and 55,577.

${ }^{16}$ Because of the rarity of the defenses studied, a median response of zero was expected for most defenses. This fact, combined with the varying case loads and specializations, led to a large standard deviation. For example, if a respondent specialized in drug cases and saw many entrapment defenses, she would have a much higher average rate of occurrence for that category and it would have a significant effect on the standard deviation, even though the response itself was reliable. 
bers found in other studies. ${ }^{17}$ The insanity defense has also been studied elsewhere, and the results of this survey also fit squarely within the results of those other studies. ${ }^{18}$ Statistically, these consistencies cannot be used to support the findings on the other studied defenses. However, if this study produced results consistent with other studies, and the same research method is being used throughout the study, then logically the consistent results for studied defenses seems to support the results for unstudied defenses. ${ }^{19}$

The defenses studied were selected to represent a wide variety of issues, with an emphasis on items that have been subject to little or no empirical study. While the states surveyed were selected to represent different geographic areas, sizes, and clarities of criminal code, it is important to note that the survey is not intended to be representative of other states or of the nation as a whole. ${ }^{20}$ Surveys were mailed to every judge in courts with general jurisdiction over felony cases. Each state surveyed has municipal courts that handle misdemeanor cases. However, judges in these courts were not included, with one exception: surveys were mailed to both the limited jurisdiction Maryland district court, which has jurisdiction over misdemeanor and some felony cases, as well as to the Maryland circuit court, which has general jurisdiction over felony cases. ${ }^{21}$ It was assumed that felony cases are likely to be more intensely litigated than misdemeanor cases, and therefore that there is a greater chance that the defenses in this survey would be raised in felony cases. Surveys were sent to both sets of Maryland judges to test this hypothesis, and the results provide support for this proposition. ${ }^{22}$

${ }^{17}$ See infra notes 135-37 and accompanying text (discussing national statistics and this survey's findings).

${ }^{18}$ Infra notes 75-79 and accompanying text.

${ }^{19}$ Even if the respondents were to share some common characteristic, the results would still be valuable for demonstrating that the defenses studied do arise on a regular basis among the sample who responded.

${ }^{20}$ The determination of criminal code quality was based on the rankings in Paul H. Robinson et al., The Five Worst (and Five Best) American Criminal Codes, 95 Nw. U. L. REV. 1, 60-61 (2000). The rankings were based on whether the criminal code was clearly written, well-articulated, and comprehensive. States with codes that were vague or archaic in form, and states that still relied on case law rather than a code to define crimes, received lower ranks. The states surveyed ranked as follows: Colorado, 2; Arkansas, 3; Wisconsin, 20; Oregon, 21; Maryland, 49; Rhode Island, 49. Id.

${ }^{21}$ Because of the unique jurisdictional grant of Maryland district courts, results from judges in those courts are not included in the overall results cited throughout this paper. Not surprisingly, results from the Maryland district court judges differed markedly from other jurisdictions.

\footnotetext{
${ }^{22}$ See infra Part V.A. Surveys sent to Maryland prosecutors and defense attorneys
} 
Surveys were also mailed to every prosecutor who handled adult criminal prosecutions. ${ }^{23}$ The names of private criminal defense lawyers were obtained from Lexis-Nexis's Martindale-Hubbell database. ${ }^{24}$ Public defenders' names were obtained from offices that coordinated public defenders' offices statewide. All names from these two sources were entered into an Excel spreadsheet, and the list was randomized. Surveys were mailed to the first 170 listed defense attorneys from each state, except Oregon and Rhode Island for which there were fewer than 170 names available, and surveys were therefore mailed to all defense attorneys listed in Oregon and Rhode Island. ${ }^{25}$

Results represent the average percentage of cases per year where respondents either saw the defense personally or estimated that the defense was seen in their locale. The success rate was calculated by dividing the total number of times a defense was successful by the total number of times it was offered.

also asked whether they practiced primarily in the district or circuit courts, but this data was not included in the results because there was significant crossover among respondents, i.e., most worked in both courts and thus a separate analysis was not possible.

${ }^{23}$ Prosecutors from offices that had specific juvenile divisions were not surveyed. Some offices had policies against releasing the names of prosecutors; in these cases, arrangements were made to mail a packet of surveys to an office manager, who then distributed them within the office. To ensure that the proper yield was known, the office managers supplied the number of attorneys to whom they distributed the surveys. In such cases, it is possible that a juvenile prosecutor would have obtained a copy of the survey, or that general prosecutors would see both juvenile and adult cases and include both types of cases in their responses. Finally, in a handful of instances, prosecutors' offices declined to participate.

${ }^{24}$ Although the Martindale-Hubbell database is not comprehensive, it is one of the only resources of its kind and does provide a wealth of information on a great number of attorneys. Prosecutors and defense attorneys, unlike the judges surveyed, are not necessarily limited to felony or misdemeanor court cases. It was not possible for this study to investigate the individual caseload of each prosecutor and defense attorney surveyed, and these factors could have some influence on the results. By obtaining this information, future studies may be able to enhance our understanding of the use of criminal defenses.

${ }^{25}$ The number 170 was selected to maximize the number of surveys sent within resource constraints. Surveys were mailed to all defense attorneys in Oregon (114) and Rhode Island (118). 


\section{CRiminal Defenses: Entrapment, Statutes of Limitations, DOUBLE JEOPARDY, DIPLOMATIC IMMUNITY, INSANITY, AND REASONABLE MISTAKE OF LAW}

\section{A. Entrapment}

There are two competing rationales for the existence of the entrapment defense. The first condemns the inducement of an otherwise innocent citizen; ${ }^{26}$ the second seeks to punish police wrongdoing so as not to "[sully] the integrity of the judicial process." ${ }^{27}$ As a result, there are two different conceptual frameworks for entrapment. "Objective" entrapment focuses on the impropriety of the police on a particular occasion, rather than the defendant's pattern of behavior. ${ }^{28}$ "Subjective" entrapment asks whether the defendant had a predisposition to commit the crime and only allows the defense when the defendant was unlikely to commit the crime without the involvement of the police. ${ }^{29}$ Regardless of formulation, the underlying goal of both enactments is to deter police misconduct ${ }^{30}$ and to prevent the abuse of individual rights during criminal capture and attempts to lead an innocent person astray.

The entrapment defense is used at trial in a limited number of cases when plea negotiations and all other tactics have failed. ${ }^{31}$ This survey, while not limited to trials, found that the entrapment defense

${ }^{26}$ PAUL H. ROBINSON, CRIMINAL LAW $§ 10.3$, at 601-02 (1997).

${ }^{27} I d . \S 10.3$, at 604

${ }^{28}$ See id. $\$ 10.3$, at 601-02 (describing the qualities of objective entrapment). Arkansas statutory law uses an objective framework, ARK. CODE ANN. §5-2-209(b) (Michie 1997), but Arkansas courts also consider subjective elements, see, e.g., Harper v. State, 643 S.W.2d 585, 587 (Ark. Ct. App. 1982) (considering defendant's conduct and predisposition as a necessary element of deciding whether the police truly induced the defendant). Colorado also uses an objective test. COLO. REv. STAT. § 18-1-709 (2003).

${ }^{29}$ See Robinson, supra note $26, \S 10.3$, at 602 (describing subjective formulations of the entrapment defense). The remaining jurisdictions included in this survey (i.e., the states other than Arkansas and Colorado) employ a subjective test. OR. REV. STAT. $\S 161.275$ (2003); Grohman v. State, 267 A.2d 193, 196 (Md. 1969); State v. Jones, 416 A.2d 676, 679 (R.I. 1980); State v. Saternus, 381 N.W.2d 290, 294 (Wis. 1986).

${ }^{30}$ See Robinson, supra note $26, \S 10.3$, at 608 (noting that the subjective approach exists as a defense because, when entrapment is at issue, the officer's wrongdoing created the idea of the crime); Ben A. Hardy, The Traps of Entrapment, 3 AM. J. CRIM. L. 165, 166-67 (1974) ("[The objective] approach will not condone police or government conduct that presents too great a risk that an innocent person will be induced to commit a crime ....").

${ }^{31}$ See Hardy, supra note 30, at 188-89 (describing an apparent consensus among a group of criminal lawyers in Austin, Texas, that entrapment is a defense of last resort). 
arose in $0.08 \%$ of cases and succeeded in one-third of these cases. ${ }^{32}$ Anecdotally, respondents indicated that entrapment is mainly offered as a defense in drug cases, though to little avail. ${ }^{33}$ The defense was disproportionately encountered by urban prosecutors, who reported seeing the defense in $0.47 \%$ of their cases. ${ }^{34}$ The only defense that was bypassed by defense attorneys more often than entrapment was insanity. $^{35}$

Because an entrapment defense generally requires the defendant to admit to committing the crime as a predicate of asserting the defense, it may be that defendants bypass entrapment defenses to avoid the social stigma of being an admitted criminal. ${ }^{36}$

Broken down by state, the reported success of entrapment is generally lower in states adopting an objective rather than subjective approach. Arkansas and Colorado, the only states surveyed that use the objective standard, had respective success rates of $4.76 \%^{37}$ and $0.00 \%{ }^{38}$ Oregon and Rhode Island had much higher success rates,

${ }^{32}$ Infra app. B, at tbl.B.1. In 1976, a study of 405 federal entrapment cases over a five-year period found that only two defendants were successful in using it. Roger Park, The Entrapment Controversy, 60 MINN. L. REV. 163, 178 n.44 (1976) (noting that although 27 out of 405 cases involved reversal or acquittal for entrapment-related error, only two "involved a determination that entrapment had been established as a matter of law"). A 1993 study found entrapment being offered in $0.2 \%$ of Tennessee state trials and having a success rate of $30 \%$. Cohen et al., supra note 1, at 973 tbl.2, 975 tbl.4. At the time of Professor Cohen's survey, Tennessee generally followed the subjective rule, TENN. CODE ANN. § 39-11-505 (1997) (enacted 1989), though if the conduct of the police was particularly egregious, it could result in an acquittal regardless of the accuser's conduct, see State v. Jones, 598 S.W.2d 209, 217 (Tenn. 1980) (noting that the United States Supreme Court mentioned, in dicta, the possibility of entrapment being a due process violation (citing United States v. Russell, 411 U.S. 423, 431-32 (1973))), overruled on other grounds by State v. Shropshire, 874 S.W.2d 634 (Tenn. 1993).

${ }^{33}$ Comments from Respondents 55,623 (noting that entrapment is pleaded in any drug sale), 55585 (noting that respondent does not see entrapment defenses raised because she is not involved in cases stemming from drug buys), and 55,714 (recalling not a single successful entrapment defense in eighteen years on the bench).

${ }^{34}$ Infra app. G, at tbl.G.1.

${ }^{35}$ The insanity defense was bypassed at a rate of $0.39 \%$, while the entrapment defense was bypassed at a rate of $0.16 \%$. Infra app. B, at tbl.B.1. Fourth and Fifth Amendment claims had higher bypass rates (1.54\% and $0.99 \%$, respectively, infra app. B, at tbl.B.2), but, as discussed in Part III, these are evidentiary claims rather than defenses.

${ }^{36}$ See Cohen et al., supra note 1, at 963-64 (suggesting a social bias against criminals).

${ }_{38}$ Infra app. C, at tbl.C.1.

${ }^{38}$ Infra app. C, at tbl.C.4. 
$85.98 \%{ }^{39}$ and $50.00 \%{ }^{40}$ respectively, while Maryland ${ }^{41}$ and Wisconsin ${ }^{42}$ had approximately the same success rate as Arkansas. ${ }^{43}$ This result seems logical as it is much more difficult to demonstrate that the defendant would not have engaged in the crime but for the police misconduct (objective standard) than it is to show a defendant's prior innocence (subjective standard). This survey indicates a potential relationship between the statutory formulation of the entrapment defense and its real world success. This correlation could indicate that a legislature has the ability to stack the deck in favor of either the defendant or the prosecution depending on the formulation of the defense that it adopts.

\section{B. Statute of Limitations}

While nearly every American jurisdiction has some type of statute of limitations on felony charges, ${ }^{44}$ no empirical studies have been conducted on how often these statutes serve as a bar to prosecution. First used in England in 1623, the statute of limitations addressed concerns about the reliability of old evidence. ${ }^{45}$ A second justification for time limitations on prosecutions is to encourage society to move on and allow individuals, who may have committed wrongs long ago, to live their lives without fear that they will be prosecuted for something in the distant past. ${ }^{46}$ However, the increased reliability of DNA testing and improved forensic science arguably negate questions of reliability, and as such, some states have begun reevaluating their statutes of limitations. ${ }^{47}$

${ }^{39}$ Infra app. C, at tbl.C.10.

${ }^{40}$ Infra app. C, at tbl.C.13. land).

${ }^{41}$ See infra app. C, at tbl.C.7 (reporting $5.00 \%$ success rate for entrapment in Mary-

${ }^{42}$ See infra app. C, at tbl.C.16 (reporting $4.55 \%$ success rate for entrapment in Wisconsin).

${ }^{43}$ It should be noted that Arkansas allows some subjective elements, supra note 28, which may be a factor in its higher success rate compared to Colorado, which uses a purely objective standard.

${ }^{44}$ ROBINSON, supra note $26, \S 10.2$, at 576 \& n.1. Kentucky is the only state that has no time limitations for felonies, and there is little indication that the lack of this provision has resulted in any injustice. Paul H. Robinson \& Michael T. Cahill, LaW WithouT JUSTICE (forthcoming June 2005) (manuscript at ch3-9, on file with author).

${ }^{45}$ ROBINSON \& CAHILL, supra note 44 (manuscript at ch3-6).

${ }^{46}$ RoBINSON, supra note $26, \S 10.2$, at 579 . Under this rationalization, advances in forensic science do not significantly change the analysis of whether a time limit should exist or not.

${ }^{47}$ See, e.g., DNA Evidence Spurs States to Drop Statute of Limitations on Rape Cases, ST. 
This survey found that statute of limitations defenses were offered in nearly 2 out of every 1000 reported cases and, when offered, were one of the most successful defenses, winning in approximately half of all cases. ${ }^{48}$ Furthermore, in an additional $0.15 \%$ of reported cases, a case was not prosecuted because of concerns about a time limitation. ${ }^{49}$ While the survey does not provide context for specific instances of use, the high success rate, coupled with the cases not prosecuted, makes this defense worthy of further study. All legislatures should realize the potential impact of this defense and take action to reevaluate the lengths and appropriateness of limitations in light of new technology as applied to individual crimes.

\section{Double Jeopardy}

The rule against double jeopardy is enshrined in the Bill of Rights, which states, "nor shall any person be subject for the same offense to be twice put in jeopardy of life or limb." ${ }^{50}$ The constitutional rule on double jeopardy serves several purposes. As the Supreme Court has stated:

[T] he State with all its resources and power should not be allowed to make repeated attempts to convict an individual for an alleged offense, thereby subjecting him to embarrassment, expense and ordeal and compelling him to live in a continuing state of anxiety and insecurity, as well as enhancing the possibility that even though innocent he may be found guilty.

Further, the prohibition stems from a desire to have finality in judgments and from the belief that an acquittal carries a special weight. ${ }^{52}$ However, like many of the rules discussed in this Comment,

LOUIS POST-DisPATCH, Mar. 19, 2000, at A16 ("In 1997, Florida removed a statute of limitation on any rape case where potential DNA evidence has been collected. That year, Nevada eliminated its statute of limitations in rape cases. In California, Hawaii, Michigan, Minnesota, New Jersey, New York and Wisconsin, lawmakers are now reexamining their statutes of limitations."); Miguel Bustillo, Panel Approves Extended Rape Prosecution Statute, L.A. TIMEs, Mar. 1, 2000, at A15 ("Across the nation, statutes of limitation have come under intense criticism in recent years as a combination of groups questions whether they block justice in an age when DNA evidence can point to suspects decades after a crime occurred-and sometimes free innocent people from jail.").

${ }^{48}$ Infra app. B, at tbl.B.1.

${ }^{49}$ Infra app. B, at tbl.B.1.

${ }^{50}$ U.S. CONST. amend. V.

${ }^{51}$ Green v. United States, 355 U.S. 184, 187-88 (1957).

52 Ronald JaY Allen et AL., COMPRehensive Criminal Procedure 1353-54 (2001). The Double Jeopardy Clause also prevents the government from using a first 
it was drafted at a time when prosecutions were conducted without the benefit of modern forensic science; hence, some aspects of the rule can be, and are being, challenged. ${ }^{53}$

Double jeopardy has never been empirically studied ${ }^{54}$ despite its incorporation into the Constitution over two hundred years ago and a number of highly publicized cases where new evidence was discovered but the double jeopardy rule barred a new trial..$^{55}$ While rare, respondents reported double jeopardy being raised in $0.16 \%$ of cases and being successful about $20 \%$ of the time. ${ }^{56}$ Additionally, double jeopardy

trial to test its case and protects defendants' rights to have a trial adjudicated by the tribunal that began the evaluation of the prosecution's case. Id.

${ }^{53}$ See ROBINSON \& CAHILL, supra note 44 (manuscript at ch7-31 to -32) (discussing the problems with the current approach to double jeopardy). High recidivism rates in the United States have led some states to adopt "three strikes" laws that allow increased sentences for repeat violators. The Supreme Court has repeatedly skirted the issue of whether such laws violate constitutional double jeopardy rules. Joshua R. Pater, Recent Developments, Struck Out Looking: Continued Confusion in Eighth Amendment Proportionality Review After Ewing v. California, 123 S. Ct. 1179 (2003), 27 HARV. J.L. \& PUB. POL'Y 399, 415-16 (2003). It is because of these concerns that the principle is not as stringently applied outside the United States, where many nations, while still having the rule generally, have exceptions for extreme cases: situations where new evidence comes to light and those involving modern developments in criminal justice. See THE LAW Comm’n, Report No. 267, Double Jeopardy and Prosecution ApPEAls II 1.18 (2001) (describing a proposal to permit retrial "where there is compelling new evidence of guilt" and it would be "in the interests of justice" to do so), available at http:/ /www.lawcom.gov.uk/files/lc267.pdf. In Europe, "Article 4(2) of Protocol 7 [of the European Convention for the Protection of Human Rights and Fundamental Freedoms states] that a case may be retried if new evidence emerges, or the original proceeding was fundamentally defective." Lauri A. Moossa, Note, England's Attempt to Relax the Rule Against Double Jeopardy: Balancing Justice and Scientific Advancement with a Cornerstone of Common Law, 25 SUfFOlK TRANSNAT'L L. REV. 587, 594 (2002). In response to rising crime rates, even England (whose development of the double jeopardy rule has served as a model for many other countries, including the United States) is considering legislative changes to the rule that would reflect modern developments in forensic science. See Stephanie Francis Cahill, Britain May Change Some Ancient Rules, 1 A.B.A. J. E-REPORT 28 (July 26, 2002), LEXIS 1 ABA Journal eReport 28 (discussing proposals by the Blair government to reform double jeopardy).

${ }_{54}$ This lack of attention may be traced to two possible explanations: (1) the rule enjoys widespread support (or at least deference) despite the potential for grave injustice, and (2) the assumption that its occurrence is so rare as to outweigh the costs of having it. See Gary DiBianco, Note, Truly Constitutional? The American Double Jeopardy Clause and Its Australian Analogues, 33 AM. CRIM. L. REV. 123, 126 (1995) (noting that the adoption and subsequent development of American double jeopardy jurisprudence is "marked by a lack of debate, policy discussion, or other indicia of intent").

${ }^{55}$ See, e.g., ROBINSON \& CAHILL, supra note 44 (manuscript at ch7-21 to -30) (describing a case where photographs showing the defendant torturing and killing the victim were discovered after a defendant was acquitted of murder and thus double jeopardy prevented conviction for the murder).

${ }_{56}$ Infra app. B, at tbl.B.1. 
concerns resulted in nonprosecution in $0.08 \%$ of cases. ${ }^{57}$ Criminal law should evolve to reflect modern conceptions of justice. When conclusive evidence is discovered after an acquittal, the risk of government abuse through multiple trials is generally negated by the evidence that the crime was actually committed. Among other nations there is a growing acceptance of exceptions to the rule against double jeopardy. ${ }^{58}$ Unfortunately, the language used in the Constitution makes such an evolution difficult in the United States.

\section{Diplomatic Immunity}

Today, diplomatic immunity is justified by the theory of functional necessity, adopted in 1961 by the Vienna Convention on Diplomatic Immunity, ${ }^{59}$ under which immunity is granted as necessary for a diplomat to be able to properly carry out her duties. ${ }^{60}$ Another fundamental justification for diplomatic immunity is fear of reciprocation against our own diplomats abroad should we prosecute foreign diplomats in the United States. ${ }^{61}$ Of course, a state may waive immunity in individual cases, but in practice that almost never happens. ${ }^{62}$

While the most prevalent crimes committed by diplomats are parking violations, ${ }^{63}$ felony offenses by diplomats are rare but not in-

${ }^{57}$ Infra app. B, at tbl.B.1.

58 See supra note 53 (describing moves to adapt the rule against double jeopardy in Europe).

${ }^{59}$ Vienna Convention on Diplomatic Relations, Apr. 18, 1961, 23 U.S.T. 3227, 500 U.N.T.S. 95; see also James S. Parkhill, Note, Diplomacy in the Modern World: A Reconsideration of the Bases for Diplomatic Immunity in the Era of High-Tech Communications, 21 HASTINGS INT'L \& COMP. L. REV. 565, 572-73 (1998) (discussing the "functional necessity" grounds for honoring diplomatic immunity); Lori J. Shapiro, Note, Foreign Relations Law: Modern Developments in Diplomatic Immunity, 1989 ANN. SURV. AM. L. 281, 283 ("Functional necessity is now recognized by ... the Vienna Convention on Diplomatic Relations as a valid rationale for diplomatic immunity." (footnotes omitted)).

${ }^{60}$ RoBINSON, supra note $26, \S 10.2$, at 584 . One traditional justification for diplomatic immunity, extraterritoriality, was premised on the notion that "a diplomat resides in his home country even though he is physically located in the receiving country" and thus was only subject to personal jurisdiction in his home state. Shapiro, supra note 59, at 282. A second rationale is that the diplomat acts as a personal representative of her nation and respect for that nation "does not permit subjugation to the jurisdiction of a foreign sovereign." William F. Marmon, Jr., Note, The Diplomatic Relations Act of 1978 and Its Consequences, 19 VA. J. INT'L L. 131, 132 (1978).

${ }^{61}$ RoBINSON, supra note $26, \S 10.2$, at 584.

${ }^{62}$ See Parkhill, supra note 59, at 565-66 (asserting the rarity of waiver and citing one exception).

${ }^{63}$ In 1984, 108,000 tickets were given to diplomats in London, though by 1986 changes in laws had reduced this number to 30,000. GRANT V. MCCLANAHAN, DiPLOMATIC IMMUNITY 14 (1989). 
significant. $^{64}$ The State Department reported that between 1982 and 1988, 191 crimes were alleged to have been committed by persons with diplomatic immunity in Washington, D.C. and New York City. Another State Department study found that, in 1995, fifteen "serious" incidents occurred nationwide among the 18,350 diplomats accorded full immunity. ${ }^{66}$

Since New York City and Washington, D.C. are home to most diplomats, it is not surprising that the occurrence of the defense is rare elsewhere-of the 175,384 cases seen by respondents in this study, there were only nine reported incidents of the defense being raised, ${ }^{67}$ and the defense was successful in only three cases. ${ }^{68}$ Although there are arguments for reforming the doctrine of diplomatic immunity, ${ }^{69}$ the findings of this survey provide only marginal support for reform.

\section{E. The Overall Effect of Nonexculpatory Defenses}

At the heart of debate on nonexculpatory defenses is whether we, as a society, want to tolerate culpable individuals going unpunished. Thus far, the answer has been yes. We place greater value on deterring police and government misconduct, moving on, and ensuring good international relationships than prosecuting every culpable indi-

${ }^{64}$ See Parkhill, supra note 59, at 577-78 (reporting the extent of diplomatic crime). Note that diplomatic immunity extends to the families of diplomats as well.

${ }^{65}$ MCClanAHAN, supra note 63 , at $170 \&$ tbl.1, $171 \&$ tbl.2. More than 10,000 people in New York City and Washington, D.C. were estimated to be entitled to such immunity, including envoys to the United States and the United Nations. Id. at 171-72. The most prevalent crimes were shoplifting (63 occurrences), assault (37 occurrences), and sex offenses (23 occurrences). Id. at 170-71.

${ }^{66}$ Parkhill, supra note 59, at 577.

${ }^{67}$ Two cases were reported in Colorado, two in Maryland, three in Oregon, and two in Wisconsin. Additionally, one judge commented that he had seen the diplomatic immunity defense unsuccessfully offered two years ago. Respondent 55,789.

${ }^{68}$ Two successful cases were reported in Oregon and one in Maryland. An additional seven instances out of 132,722 were reported in which diplomatic immunity led to nonprosecution. However, all seven were reported by one respondent in Oregon, who did not offer a comment or explanation of the case(s). Respondent 55,685 .

${ }^{69}$ See, e.g., Juliana J. Keaton, Note, Does the Fifth Amendment Takings Clause Mandate Relief for Victims of Diplomatic Immunity Abuse?, 17 HASTINGS CONST. L.Q. 567, 569 (1990) (advocating payments by the U.S. government to persons harmed by diplomats who cannot be successfully prosecuted); Parkhill, supra note 59, at 588-95 (offering suggestions for reform); Shapiro, supra note 59, at 294-306 (detailing various reform proposals); Stephen L. Wright, Note, Diplomatic Immunity: A Proposal for Amending the Vienna Convention to Deter Violent Criminal Acts, 5 B.U. INT'L L.J. 177, 184 (1987) (proposing amending the Vienna Convention to provide an international mechanism for trying diplomats). 
vidual. This survey shows that such defenses do arise and those who advocate against the reform of these rules can no longer use their complete irrelevance as an excuse, though they can continue to assert that they are rare. On the other hand, advocates for change can point to these numbers to suggest that the issues arise often enough to merit a serious consideration of the costs and benefits of the rules as they are currently applied. Furthermore, the links seen between the formulation of the entrapment defense and its relative success suggest that statutory reform may be used to effectively craft defenses in a way that achieves the appropriate balance between each rule's costs and benefits.

\section{F. Insanity}

Generally classified as an excuse, ${ }^{70}$ the insanity defense has multiple formulations. ${ }^{71}$ The M'Naghten test asks whether the defendant knew right from wrong and understood the nature of her act at the time of commission. ${ }^{72}$ The M'Naghten test is often combined with the irresistible impulse test which adds an element regarding a person's ability to control her actions. ${ }^{73}$ The American Law Institute's (ALI) Model Penal Code considers whether the defendant "lacks substantial capacity either to appreciate the criminality [wrongfulness] of his conduct or to conform his conduct to the requirements of law." ${ }^{, 74}$

${ }^{70}$ RoBINSON, supra note $26, \S 9.3$, at 511 .

71 Id. at 512 .

${ }^{72}$ M'Naghten's Case, 8 Eng. Rep. 718 (H.L. 1843), described in RoBINSON, supra note $26, \S 9.3$, at 512 .

${ }^{73}$ ROBINSON, supra note 26, $\S 9.3$, at 513. Nearly half of the American jurisdictions follow the M'Naghten test. ROBINSON \& CAHILL, supra note 44 (manuscript at ch2-12). Colorado follows a modified version of the M'Naghten test. COLO. REV. STAT. $\S 16-8-101.5$ (2003) (excusing criminal conduct under an insanity defense when a person is "so diseased or defective in mind at the time of the commission of the act as to be incapable of distinguishing right from wrong... [or] forming a culpable mental state that is an essential element of a crime charged").

${ }^{74}$ MOdel Penal CODE $\$ 4.01$ (1) (1962) (brackets in original). Five of the jurisdictions in this survey use the Model Penal Code formulation. See ARK. Code ANN. § 52-312(a) (1) (Michie Supp. 2003) ("It is an affirmative defense ... [if] at the time the defendant engaged in the conduct charged, he or she lacked capacity ... to conform his or her conduct to the requirements of law or to appreciate the criminality of his or her conduct."); MD. Code ANN., CRIM. Proc. § 3-109 (2001) (“A defendant is not criminally responsible for criminal conduct if, at the time of that conduct, the defendant . . lacks substantial capacity to: (1) appreciate the criminality of that conduct; or (2) conform that conduct to the requirements of law.”); OR. REV. STAT. § 161.295(1) (2003) ("A person is guilty except for insanity if, as a result of mental disease or defect at the time of engaging in criminal conduct, the person lacks substantial capacity ei- 
Several studies show a great divide between popular perceptions of the use of the insanity defense and its actual use. ${ }^{75}$ While surveys have shown that the public believes the defense is raised in as many as $50 \%$ of all trials, in reality the defense is raised infrequently, with one study reporting its use in only $0.9 \%$ of all felony indictment cases tried. $^{76}$ That same study further reports that only $26 \%$ of those seeking the defense are acquitted ${ }^{77}$ the majority are sent to a mental hospital.

This survey's results, while not limited to trial settings, parallel these statistics. First, the reported occurrence and success rates for insanity defenses are $0.87 \%$ and $23.55 \%,{ }^{78}$ respectively-which places this study's findings in the same range of findings by other studies. Despite the infrequency with which surveyed lawyers encountered the defense themselves, they assumed it arose even less often among others in their locale $(0.37 \%)$ and that it was less successful among other cases in their locale $(10.04 \%)$ than in their own cases $(23.55 \%){ }^{79}$

The regional breakdown shows a much higher reported incidence of the defense in rural areas. ${ }^{80}$ Arkansas, a state with a large rural population, ${ }^{81}$ indicated a significantly higher occurrence rate and a

ther to appreciate the criminality of the conduct or to conform the conduct to the requirements of law."); WIS. STAT. ANN. $§ 971.15$ (1) (West 1996) (“A person is not responsible for criminal conduct if at the time of such conduct as a result of mental disease or defect the person lacked substantial capacity either to appreciate the wrongfulness of his or her conduct or conform his or her conduct to the requirements of law."); State v. Johnson, 399 A.2d 469, 476 (R.I. 1979) (adopting the Model Penal Code test for criminal responsibility). This occurrence is somewhat odd considering that nearly half of American jurisdictions use the M'Naghten test, while only about $20 \%$ use the Model Penal Code. RoBinson \& CAHILl, supra note 44 (manuscript at ch212).

${ }^{75}$ See, e.g., Eric Silver et al., Demythologizing Inaccurate Perceptions of the Insanity Defense, 18 LAW \& HuM. BEHAV. 63, 67 (1994) ("The public's estimate of the insanity plea rate ... far exceeds the actual plea rate.").

${ }^{76} \mathrm{Id}$; see also Cohen et al., supra note 1, at 973 tbl.2 (finding the insanity defense is offered in $0.7 \%$ of trials in Tennessee)

${ }^{77}$ Silver et al., supra note 75 , at 67.

${ }^{78}$ Infra app. B, at tbl.B.1.

${ }^{79}$ Infra app. B, at tbl.B.1.

${ }^{80}$ Compare infra app. D, at tbl.D.7 (showing an occurrence rate of $1.18 \%$ in rural areas), with infra app. D, at tbls.D.1, D.4 (showing occurrence rates of $0.79 \%$ and $0.60 \%$ in urban and suburban areas, respectively).

${ }^{81}$ Univ. of Ark.-Fayetteville, Definitions for Rural Profile of Arkansas 1997, at http://www.uark.edu/depts/hesweb/hdfsrs/definitions.html (last modified Nov. 7, 1997) ("Nationally, $24.8 \%$ of the population was rural ... as of the 1990 Census. Arkansas, however, was $46.5 \%$ rural and ranked eleventh in the nation."). 
much lower success rate than other states. ${ }^{82}$ Colorado, the only state surveyed that employs the M'Naghten test, ${ }^{83}$ had the highest reported success rate for the defense at $35.33 \%,{ }^{84}$ but several of the states using the Model Penal Code reported similar rates. ${ }^{85}$

The insanity defense was reported bypassed more often than any other defense, ${ }^{86}$ but can be effective in leading to nonprosecution $(0.12 \%){ }^{87}$ Respondents' comments support this conclusion, as they indicated that civil commitment or other such measures were often employed in lieu of criminal prosecution in those cases where a defendant had serious mental illness. ${ }^{88}$

Some respondents commented that they have seen a rise in the number of crimes committed by mentally ill individuals. ${ }^{89}$ One reasoned that

[i]nsanity defenses are on the rise, as are the percentage of criminal defendants who suffer from mental illness. As the mental health system becomes ever more underfunded, the criminal justice system has been misused to replace it. The mentally ill wind up in jail or prison or under criminal commitment orders.

This study is consistent with previous research ${ }^{91}$ in finding that, contrary to public perception, insanity defenses are not an over-

${ }^{82}$ See infra app. C, at tbl.C.1 (reporting a $2.30 \%$ occurrence rate and a $5.92 \%$ success rate).

${ }^{83}$ See supra notes 72-74 and accompanying text.

${ }^{84}$ Infra app. C, at tbl.C.4.

${ }^{85}$ See infra app. C, at tbl.C.10 (reporting a success rate of $33.7 \%$ in Oregon); infra app. C, at tbl.C.13 (reporting a success rate of $33.3 \%$ in Rhode Island); infra app. C, at tbl.C.16 (reporting a success rate of $30.7 \%$ in Wisconsin). These findings may indicate that, at least between the M'Naghten and Model Penal Code tests, the formulation has little effect on usage and success of the insanity defense and any reform intending fundamental change must go beyond these formulations. See Lisa Callahan et al., Insanity Defense Reform in the United States-Post-Hinckley, 11 MENTAL \& PHYSICAL DISABILITY L. REP. 54, 54-60 (1987) (surveying insanity defense reform movements across the United States after Hinckley's successful use of the insanity defense in his trial for shooting President Reagan).

${ }^{86}$ See infra app. B, at tbl.B.1 (showing a bypass rate of $0.39 \%$ for the insanity defense; the next highest bypass rate for a defense was $0.16 \%$ for entrapment).

${ }^{87}$ Infra app. B, at tbl.B.1. Among the six defenses studied, insanity was second only to statutes of limitations $(0.15 \%)$ for the rate of nonprosecution. Infra app. B, at tbl.B.1.

${ }^{88}$ Respondents 55,584 and 55,960.

${ }^{89}$ Respondents 55,585, 55,724, and 55,738.

${ }^{90}$ Respondent 55,738.

${ }^{91}$ See Cohen et al., supra note 1, at 969-70 (reporting results of a survey of Tennessee judges, prosecutors, and defense lawyers that examined the use, success, and outcomes associated with the insanity defense); Silver et al., supra note 75, at 67 (reporting 
whelming burden on the system. As the above-quoted respondent noted, the insanity defense is subject to more external factors than other defenses studied here. With that in mind, further study of the impact of those factors on the use of the defense is necessary before effective reforms can be adopted.

\section{G. Reasonable Mistake of Law ${ }^{92}$}

Many states seem to believe that the integrity of their legal codes demands rejection of the reasonable mistake of law defense. ${ }^{93}$ Another concern is that such a defense would be "easy to claim and hard to disprove." ${ }^{94}$ However, no empirical research has been conducted on whether the existence of a reasonable mistake of law defense has the dangerous slippery slope effect that its critics fear. ${ }^{95}$ While a few states recognize such a defense in broad terms, ${ }^{96}$ a number of other jurisdictions provide a limited form of the defense when a law has not been made public (six state jurisdictions) or an individual relied on an official misstatement of the law (twenty-three state jurisdictions) ${ }^{97}$

Respondents saw the defense raised in $0.12 \%$ of cases, and it was successful $24.88 \%$ of the time. ${ }^{98}$ Prosecutors and defense attorneys reported higher rates at which the defense was offered as compared to

results from a study of the insanity defense in eight states).

${ }^{92}$ The applicable rules for the states surveyed are: ARK. CODE ANN. § 5-2-206 (Michie 1997) (providing that a mistake of law defense is available if a person relied on official misstatement or if it is relevant to the requisite mental state); COL. REV. STAT. $\S$ 18-1-504 (2003) (permitting a mistake of fact defense if it negates the requisite mens rea); OR. REV. STAT. $§ \S 161.095,161.115$ (4) (2003) (providing that a mistake of law or fact is irrelevant "unless the statute clearly so provides," however, a person must act with a "culpable mental state with respect to each material element" of a crime in order to be found guilty); WIS. STAT. ANN. $\$ 939.43$ (West 1996) ("An honest error ... is a defense if it negatives the existence of a state of mind essential to the crime."); Hopkins v. State, 69 A.2d 456, 460 (Md. 1949) (refusing to recognize a mistake of law defense, even if a defendant relied on a state attorney's interpretation of the law).

${ }^{93}$ See, e.g., People v. Marrero, 507 N.E.2d 1068, 1069-70 (N.Y. 1987) (mentioning fear of encouraging ignorance of the law as one reason for not allowing the defense).

${ }^{94}$ ROBINSON \& CAHILL, supra note 44 (manuscript at ch2-4).

${ }^{95}$ Marrero, 507 N.E.2d at 1069.

${ }^{96}$ See, e.g., N.J. STAT. ANN. § 2C:2-4(c) (3) (West 2004) (authorizing the use of the defense when " $[\mathrm{t}]$ he actor ... diligently pursues all means available to ascertain the meaning and application of the offense to his conduct and honestly and in good faith concludes his conduct is not an offense"); WIS. STAT. ANN. $\$ 939.43$ (West 1996) ("An honest error ... is a defense if it negatives the existence of a state of mind essential to the crime.").

${ }^{97} 2$ PAUl H. Robinson, CRIMINAL LAW DEFENSES $§ § 182(a)-83(a)$ (1984).

${ }^{98}$ Infra app. B, at tbl.B.1. 
that observed by judges $(0.30 \%$ and $0.42 \%$ versus $0.04 \%) .{ }^{99}$ That respondent judges rarely saw this defense may indicate that it played a role in disposing of cases before they had a chance to go before a judge. Since the defense is unlikely to be offered with regard to major crimes, prosecutors may offer more generous pleas to defendants who commit honest mistakes. Since a plea would be different than nonprosecution, this may also explain why so few prosecutors $(0.05 \%)$ saw the defense as resulting in nonprosecution. ${ }^{100}$

Robinson and Cahill raise an additional concern that

[r] ecent years have seen a dramatic increase in the number of criminal offenses that punish minor or obscure regulatory infractions ... many of them carry[ing] the potential for serious punishment.... [W] hen coupled with a refusal to acknowledge that these numerous and complex rules are not intuitive or well-known and that otherwise law-abiding people might violate them without realizing it, a great risk arises that unjust liability will be imposed frequently. ${ }^{101}$

The ever increasing number of regulatory "crimes" increases the likelihood that individuals will be charged with crimes that bear no relationship to social morals and are not readily understood as crimes by an ordinary person. ${ }^{102}$ While it may be going too far to grant blanket acquittals for reasonable mistakes, a formulation of the rule that decriminalizes certain offenses when a reasonable mistake of law is proven may be more reasonable in these circumstances. Given the current absence of any indication of a slippery slope effect, such a compromise would allow civil punishment while reserving the weight of criminal sanctions for more deserving culprits.

\section{Constitutional Evidentiary Provisions}

The U.S. Constitution affords defendants a number of rights to protect them from undue influence from authorities and invasions of privacy. ${ }^{103}$ Survey questions on these issues were formulated differ-

${ }^{99}$ Infra app. E, at tbl.E.1.

${ }^{100}$ Infra app. E, at tbl.E.1.

101 ROBINSON \& CAHILL, supra note 44 (manuscript at ch2-5).

${ }^{102} I d$. For further discussion of regulatory crimes' relationship (or lack thereof) to social morals, see Stuart P. Green, Why It's a Crime to Tear the Tag off a Mattress: Overcriminalization and the Moral Content of Regulatory Offenses, 46 EMORY L.J. 1533 (1997).

${ }^{103}$ See, e.g., U.S. CONST. amends. I, II, III, IV, V, VI, VIII (enshrining numerous individual rights); see also Fred H. Cate, The Changing Face of Privacy Protection in the European Union and the United States, 33 IND. L. REV. 173, 198-201 (1999) (discussing the high value placed on the right to privacy in America and the limited exceptions to this 
ently than those on the above defenses since, in practice, they are not defenses, but rather are issues that usually arise in pre-trial motions. Other studies have sought to quantify the success of such motions in suppressing evidence and to demonstrate the relationship between successful motions and trial outcomes. ${ }^{104}$ This survey attempts to demonstrate the latter by allowing respondents to estimate how often they believe successful exclusions led to dismissal, acquittal, or nonprosecution. $^{105}$

\section{A. Fourth Amendment and the Exclusionary Rule}

The Fourth Amendment protects the "right of the people to be secure in their persons, houses, papers, and effects, against unreasonable searches and seizures," alike from government intrusion into their private lives. The exclusionary rule is an extension of the Fourth Amendment and bars the admission of evidence at trial that was illegally obtained by authorities. ${ }^{107}$ Furthermore, under the "fruit of the poisonous tree" doctrine, any subsequent evidence of wrongdoing that is discovered as a result of an illegal search is also excluded. ${ }^{108}$ The rule is meant to deter police from violating individual rights ${ }^{109}$ and serves to maintain the in-

right).

${ }^{104}$ See W. Robert Burkhart et AL., U.S. DeP'T Of Justice, The EFFects of the EXCLUSIONARY RULE: A STUDY IN CALIFORNIA 18 (1982) (assessing the effects of the exclusionary rule); Thomas Y. Davies, A Hard Look at What We Know (and Still Need to Learn) About the "Costs" of the Exclusionary Rule: The NIJ Study and Other Studies of "Cost" Arrests, 1983 AM. B. FoUND. RES. J. 611, 621 (stating that the exclusionary rule led to nonprosecution and/or nonconviction in between $0.6 \%$ and $2.35 \%$ of felony arrests in those jurisdictions under study); Nardulli, supra note 3, at 590-94 (reviewing case files to find correlations between successful motions and acquittals); Stephen J. Schulhofer, Miranda's Practical Effect: Substantial Benefits and Vanishingly Small Social Costs, in THE MIRANDA DEBATE 191-92 (Richard A. Leo \& George C. Thomas III eds., 1998) (examining, empirically, the detectable harm the exclusionary rule causes to law enforcement).

105 See infra app. A.

${ }^{106}$ U.S. CONST. amend. IV.

107 The United States Supreme Court established the exclusionary rule in 1914, Weeks v. United States, 232 U.S. 383, 398 (1914), and extended it to the states in 1961, Mapp v. Ohio, 367 U.S. 643, 655 (1961).

${ }^{108}$ See Wong Sun v. United States, 371 U.S. 471, 487-88 (1963) (stating that key evidence obtained by illegal searches was "come at by the exploitation of that illegality" and was therefore inadmissible).

${ }^{109}$ See Mapp, 367 U.S. at 656 ("[T] he purpose of the exclusionary rule "is to deter-to compel respect for the constitutional guaranty in the only effectively available way-by removing the incentive to disregard it." (quoting Elkins v. United States, 364 U.S. 206, $217(1960)))$. 
tegrity of the judicial process by preventing courts from endorsing a constitutional violation. ${ }^{110}$

While the Fourth Amendment protects all Americans, the exclusionary rule only comes into consideration when there is evidence of a crime. The Supreme Court has made it clear that the exclusion of evidence under the rule is not a constitutional right but a necessary mechanism for ensuring that government authorities respect the Constitution. ${ }^{111}$ Previous studies have shown that the exclusionary rule has had a significant impact on convictions and have raised concerns as to the toll that Fourth Amendment search and seizure challenges have on law enforcement. ${ }^{112}$

This survey differs from previous studies because, instead of focusing on statistical correlations, it asked respondents to evaluate direct links between excluded evidence and acquittals based on their perceptions of the cases they handle. ${ }^{13}$ Respondents reported that a suppression motion was made in $7.34 \%$ of all cases, led to acquittal or dismissal in $11.62 \%$ of the cases where the motion was made, and resulted in nonprosecution in an additional $0.69 \%$ of cases. ${ }^{114}$ These responses suggest that there could be a significant number of lost convictions due to Fourth Amendment challenges and add fuel to the debate concerning the best way to deter government abuse of individual rights without impeding the capture and conviction of criminals.

${ }^{110}$ See Thomas S. Schrock \& Robert C. Welsh, Up from Calandra: The Exclusionary Rule as a Constitutional Requirement, 59 MINN. L. REV. 251, 257-60 (1974) (explaining the judicial integrity rationale).

${ }^{111}$ See United States v. Calandra, 414 U.S. 338, 348 (1974) (holding that the exclusionary rule is a "judicially created remedy... rather than a personal constitutional right").

${ }^{112}$ In the early 1980s, Peter Nardulli studied 7500 individual case files and counted the number of Fourth, Fifth, and Sixth Amendment suppression motions filed and the success rates of those motions. Nardulli, supra note 3, at 590-92. His study found that $5 \%$ of cases had motions filed to suppress physical evidence and that $17 \%$ of these motions were successful. Id. at 593, 595 tbl.2, 596. In cases where the suppression motion was granted, the study further found that $78 \%$ of persons who succeeded in getting the evidence excluded were later acquitted at trial. Id. at 600,601 tbl.12. A study conducted in California from 1976 through 1979 found that in $4.8 \%$ of the cases rejected by prosecutors' offices, the prosecutors cited search and seizure problems as the primary cause of rejection. BURKHART ET AL., supra note 104, at 10. Of those released due to such search and seizure concerns in 1976 and 1977, 45.8\% were arrested again within a two-year follow-up period. Id. at 16 tbl.7.

\footnotetext{
${ }^{113}$ Infra app. A.

${ }^{114}$ Infra app. B, at tbl.B.2.
} 


\section{B. Fifth Amendment and Miranda Warnings}

The Constitution provides that no person "shall be compelled in any criminal case to be a witness against himself." ${ }^{, 15}$ In 1966, the Supreme Court sought to safeguard this privilege against selfincrimination when it held in Miranda $v$. Arizona that "the prosecution may not use statements, whether exculpatory or inculpatory, stemming from custodial interrogation of the defendant unless it demonstrates the use of procedural safeguards effective to secure the privilege against self-incrimination." ${ }^{116}$ Debate immediately ensued as to whether the convictions lost under the new rule outweighed the benefit of having the constitutional safeguard. ${ }^{117}$

While the empirical costs of the Miranda rule are hotly debated, ${ }^{118}$ this survey found that the motions were made in $3.97 \%$ of cases and succeeded $9.86 \%$ of the time. ${ }^{119}$ As with the discussion of the Fourth Amendment, the data from this survey add to the debate as to

115 U.S. CONST. amend. V.

116 Miranda v. Arizona, 384 U.S. 436, 444 (1966). The safeguards were set forth by the Court as follows:

Prior to any questioning, the person must be warned that he has a right to remain silent, that any statement he does make may be used as evidence against him, and that he has a right to the presence of an attorney, either retained or appointed. The defendant may waive effectuation of these rights, provided the waiver is made voluntarily, knowingly and intelligently. If, however, he indicates in any manner and at any stage of the process that he wishes to consult with an attorney before speaking there can be no questioning. Id. at 444-45.

117 See, e.g., THE MIRANDA DEBATE, supra note 104 (presenting essays debating the value of the rule). Subsequent decisions have refined and softened the rule, but it has weathered numerous challenges, and, following the 2000 decision in United States v. Dickerson, 530 U.S. 428 (2000), it seems highly unlikely that it will be overturned. Yale Kamisar, Foreward: From Miranda to $\S 3501$ to Dickerson to . ., 99 MICH. L. REV. 879, 885-92, 896-97 (2001).

${ }^{118}$ While Professor Cassell tentatively finds that after Miranda a reduction in the number of confessions led to an overall loss of as many as $3.8 \%$ of all convictions, Cassell, supra note 104, at 437-38, Professor Schulhofer finds it to be at most $0.78 \%$, Schulhofer, supra note 104, at 192. One study of burglary and theft found that less than $4 \%$ of cases had exclusionary problems involving a confession. FLOYD FEENEY ET AL., U.S. DeP'T OF Justice, ArRests Without Conviction: How Often They OCCuR AND WHY 144 (1983). The Nardulli study found that motions to suppress confessions were filed in $6.6 \%$ of all cases and were successful in $2.3 \%$ of cases. Nardulli, supra note 3 , at 595 tbl.2, 596, 597 tbl.7. In cases where the motion to suppress a confession was granted, the study found that $41.7 \%$ were acquitted at trial as opposed to $12.4 \%$ acquitted when the motion was denied. $I d$. at 601 tbl.12. However, it should be noted that only twelve motions to suppress were granted, compared with 458 denied, thus limiting the significance of this comparison. Id.

${ }^{119}$ Infra app. B, at tbl.B.2. 
whether the costs of the rule outweigh the benefits. Future reform measures may need to address both the number of times the defense is raised and its rate of success.

\section{Sixth Amendment Identification Procedures}

Protections surrounding identification procedures are based on the fact that eyewitness testimony is inherently unreliable. ${ }^{120}$ Identification challenges seek to exclude unreliable rather than ill-gotten but reliable evidence, and they can be raised at various points during a trial. ${ }^{121}$ Nonetheless, there is a lively debate as to how to properly safeguard defendants from faulty eyewitness testimony. ${ }^{122}$

Respondents to this survey reported an even lower occurrence of identification suppression motions $(1.20 \%)^{123}$ than found elsewhere, ${ }^{124}$

${ }^{120}$ See Stanley Z. Fisher \& Ian McKenzie, A Miscarriage of Justice in Massachusetts: Eyewitness Identification Procedures, Unrecorded Admissions, and a Comparison with English Law, 13 B.U. PUB. INT. L.J. 1, 3 (2003) (asserting that problems with eyewitness identification are "well known"); Benjamin E. Rosenberg, Rethinking the Right to Due Process in Connection with Pretrial Identification Procedures: An Analysis and a Proposal, 79 KY. L.J. 259, 260-61 (1990) (noting various concerns regarding eyewitness reliability). Forensic science offers substantial evidence of the dangers associated with eyewitness testimony: studies have shown that in $85 \%$ of cases where DNA evidence has overturned a conviction, eyewitness testimony played a critical role in the conviction. Lisa Steele, Trying Identification Cases: An Outline for Raising Eyewitness ID Issues, CHAMPION, Nov. 2004, at 8, available at http://www.nacdl.org/public.nsf/01c1e7698280d20385256d0b00789923 /9973f3ec244ba99685256f6a00558f39?opendocument; see also Winn S. Collins, Looks Can Be Deceiving: Safeguards for Eyewitness Identification, WIS. LAW., Mar. 2004, at 8 (discussing several cases where misidentification led to convictions that were later overturned on DNA evidence), available at http://www.wisbar.org/wislawmag/2004/03/ collins.html.

${ }^{121}$ See Steele, supra note 120, at 8 (discussing the "seven places where counsel can raise eyewitness issues").

${ }^{122}$ See, e.g., Edward Stein, The Admissibility of Expert Testimony About Cognitive Science Research on Eyewitness Identification, 2 LAW, PROBABILITY \& RISK 295, 295 (2003) (analyzing whether and when courts should allow experts to testify about memory and cognition problems relating to eyewitness identifications); Scott Woller, Note, Rethinking the Role of Expert Testimony Regarding the Reliability of Eyewitness Identifications in New York, 48 N.Y.L. SCH. L. REV. 323, 323-24 (2003) (arguing that New York should adopt a new standard on the admissibility of expert testimony on eyewitness identifications).

${ }^{123}$ Infra app. B, at tbl.B.2.

${ }^{124}$ The Nardulli study found that motions to suppress on Sixth Amendment identification procedure grounds were filed in $4.8 \%$ of all cases, and the motion was granted $1.6 \%$ of the time. Nardulli, supra note 3, at 594, 595 tbl.2, 596, 597 tbl.7. The study further found that $16.7 \%$ of persons who succeeded in getting the identification suppressed were later acquitted at trial. Id. at 600, 601 tbl.12. However, this statistic is derived from one lost conviction out of six cases, and therefore may be misleading. 
and a success rate of $5.75 \%$ for such motions. ${ }^{125}$ These low figures are somewhat surprising considering the recent studies that link eyewitness testimony to erroneous convictions that are later overturned by DNA evidence. ${ }^{126}$ Despite the weight of studies showing how unreliable such evidence can be, the low success rate gives practicing lawyers little incentive to pursue these motions. Further corroborating studies might suggest a need for reform.

\section{Overall Effect of the Fourth, Fifth, and Sixth Amendment Exclusionary Rules}

Many critics argue that the number of cases "lost" to these rules is so negligible that the benefit to society must surely outweigh the cost. ${ }^{127}$ Indeed, one extensive study of the exclusionary rule in California found that it almost never led to the exclusion of evidence in cases involving non-drug crimes. ${ }^{128}$ However, the reported recidivism rates suggest that these may not be harmless individuals who pose little threat to society. ${ }^{129}$ Studies, including this one, remind us that these rules do result in lost convictions of criminals and should encourage us to reevaluate whether this loss is tolerable in order to deter invasions of privacy.

These rules also have a practical impact on the criminal justice system: the administrative cost of dealing with these motions is high. Some respondents complained that motions to suppress evidence are made in almost every case on any number of issues and may be made to irk the prosecutor, buy time, or as a means of protecting the defense attorney from later accusations of malpractice. ${ }^{130}$ The issue, therefore, requires consideration beyond whether it releases blameworthy individuals into society. If it raises the costs of the administration of justice and adds to the already overburdened criminal justice system, then injustice may be propagated in other ways.

Anecdotal evidence from this survey suggests that some prosecutors have taken matters into their own hands. One respondent prose-

${ }^{125}$ Infra app. B, at tbl.B.2.

${ }^{126}$ See supra note 120.

127 See Davies, supra note 104, at 689 (arguing that studies on the issue show the real world effects of the defense to be negligible); Nardulli, supra note 3, at 606-09 (arguing that the exclusionary rule's "marginal effect on the criminal court system" indicates that the current system's benefits may outweigh its costs).

${ }^{128}$ Davies, supra note 104, at 645.

${ }^{129}$ BURKHART ET AL., supra note 104, at 15.

${ }^{130}$ Respondents 55,555, 55,570, 55,607, 55,655, and 55,754. 
cutor stated that "if I have to bring in witnesses for motions hearings I will withdraw all [plea] offers." eral other respondent prosecutors, who noted the need for such measures in the face of daunting caseloads, ${ }^{132}$ and defense attorneys, who lamented its chilling effect on constitutional rights. ${ }^{133}$ This Comment by no means calls for abolishing the protections, but rather acknowledges that problems exist and hopes that reforms are explored. ${ }^{134}$

\section{Plea Negotiations}

Plea negotiations are one of the most important and prevalent features of modern criminal law, with $95 \%$ of all felony convictions in state cases arising from guilty pleas. ${ }^{135}$ Respondents commented on the role of plea negotiations more often than anything else studied. This survey found pleas offered at an overall rate of $94.03 \%$, ${ }^{136}$ with prosecutors and defense attorneys encountering plea offers at similar rates of $96.81 \%$ and $97.62 \%$ of cases, while judges perceive such offers in $90.06 \%$ of cases. ${ }^{137}$ Of those cases where some form of plea was offered, the acceptance rate estimated by judges, prosecutors, and defense attorneys was close to the overall average of $85.28 \% .^{138}$

One of the more interesting findings of this survey is not the rate of plea bargains itself, but rather the breakdown of the outcomes of the pleas. This survey divided plea results into three categories: those who pled guilty to a lesser charge (and therefore received a shorter sentence); those who pled guilty to the charge but were offered leni-

${ }^{131}$ Respondent 55,655.

${ }^{132}$ Respondents 55,560, 55,566, and 55,674.

${ }_{133}$ Respondents 55,864 and 55,946.

134 See generally AKHIL ReEd Amar, The Constitution ANd CRIMINAL Procedure (1997) (giving an overview of criminal procedure and offering sound philosophical frameworks for reform).

${ }^{135}$ Bureau of Justice Statistics, U.S. Dept. Of Justice, Bulletin NCJ 198821, FELONY SENTENCES IN STATE COURTS 9 tbl.10 (2003), available at http://www. ojp.usdoj.gov/bjs/pub/pdf/fssc00.pdf; see also RALPH ADAM FINE, ESCAPE OF THE GUILTY 3 (1986) (estimating that between $75 \%$ and $90 \%$ of felonies are pled out); THE REAL WAR ON CRIME: THE Report OF THE NATIONAL CRIMINAL JUSTICE COMMISSION 182 (Steven R. Donziger ed., 1996) (estimating the rate of felony cases pled out in some form to be over $90 \%$ ).

${ }_{137}^{136}$ Infra app. B, at tbl.B.3.

${ }^{137}$ Infra app. E, at tbl.E.3.

${ }^{138}$ Compare infra app. E, at tbl.E.3, with infra app. B, at tbl.B.3. The survey did not ask about the outcome of those cases in which a defendant did not accept the plea offer. 
ency in sentencing; and those whose charges were dropped. Assuming these categories are mutually exclusive, the sum of these three categories should represent $100 \%$ of the accepted pleas in this survey. However, the three categories add up to $139 \%$, indicating that there is overlap between the categories. ${ }^{139}$ There are a number of factors that could cause this overlap. For example, respondents in the survey often commented that judges are not bound by any recommendations for leniency made by prosecutors. ${ }^{140}$ Thus, a defendant has no guarantee that she will receive a lesser sentence upon pleading guilty to a lesser charge. Further, a defendant may be charged with several crimes and the plea may encompass dropping some charges completely, lowering the grade of some charges, and/or asking for leniency on certain charges. ${ }^{141}$

Finally, for $10.89 \%$ of reported defendants, a plea offer resulted in nonprosecution. ${ }^{142}$ This question was formulated broadly to encompass cases where pleas led to charges being dropped for any reason: immunity in exchange for testimony, alternative dispute resolution, and other such circumstances. ${ }^{143}$ With overcrowded prisons a persistent problem, ${ }^{144}$ these reported arrangements may reflect a growing role for alternative sentencing and present an opportunity to develop a sentencing scheme aimed at rehabilitation instead of expanding the prison system.

\section{General Observations}

\section{A. The Results of the District Court Survey}

The reported results of the Maryland district court, which has jurisdiction over misdemeanor and certain felony cases, differed greatly from the other results. ${ }^{145}$ Respondent Maryland district court judges

139 Infra app. B, at tbl.B.3.

${ }^{140}$ Respondents 55,789, 55,802, 55,810, and 55,956.

141 Respondents 55,585 (discussing practice of pleading to one count in exchange for dropping a second) and 55,607 (noting that a prosecutor respondent will drop speeding charges in exchange for a guilty plea to driving while intoxicated).

142 Infra app. B, at tbl.B.3.

143 Anecdotally, some respondents indicated that they included alternative remedies in this category, e.g., counseling or rehabilitation programs upon the completion of which charges may be dropped or the defendant's record expunged.

${ }^{144}$ See generally Alfred Blumstein et al., Mass Incarceration: Perspectives on U.S. Imprisonment, 7 U. CHI. L. SCH. ROUNDTABLE 91 (2000) (discussing the "incarceration crisis" in the United States and the problems it causes).

${ }^{145}$ Even though the sample size is much smaller in this category than others, see 
saw an average of 2073 criminal cases per year, compared with 450 for Maryland circuit court judges. While statute of limitations and reasonable mistake of law defenses arose much more often in the district courts, ${ }^{146}$ the other defenses studied appeared much less often. ${ }^{147}$ These results may indicate that certain defenses arise more often in felony versus misdemeanor cases and vice versa. Further research on these differences would be valuable in understanding the overall effect of reforming criminal defenses.

\section{B. Role of the Defenses and Claims in Plea Bargains}

Prosecutors, defense attorneys, and judges all cited their heavy caseloads as a determining factor in many of their plea decisions (i.e., their decisions about what and how to plead). ${ }^{14}$ As such, many respondents noted that the defenses studied play a significant role in plea bargaining. ${ }^{149}$ As one respondent commented, the "existence of a valid defense in a case is most potent at charging if it is brought to the attention of the prosecutor issuing the charges." 150 Likewise, defense attorneys noted that a good defense was a strong bargaining chip. ${ }^{151}$ One attorney summed up the situation: "In our jurisdiction, most (by far) cases are resolved by plea agreement. Defenses are raised by negotiation much more than litigation. Counsel then evaluate [the] strength of defenses and then adjust the 'value' of the case accordingly." 152

infra app. C (showing $n$ values—i.e., the number of respondents for each category-for each state), it provides some indication of possible differences.

${ }^{146}$ Compare infra app. F, at tbl.F.7 (showing statute of limitation defenses arising in $0.42 \%$ of cases heard by district court judges and only $0.21 \%$ of cases heard by circuit court judges), with infra app. E, at tbl.E.1 (showing statute of limitation defenses arising in $0.18 \%$ of cases heard by judges, excluding Maryland district court judges); infra app. F, at tbl.F.7 (showing mistake of law defenses arising in $0.11 \%$ of cases heard by district court judges and only $0.07 \%$ of cases heard by circuit court judges), with infra app. E, at tbl.E.1 (showing mistake of law defenses arising in $0.04 \%$ of cases heard by judges, excluding Maryland district court judges).

${ }^{147}$ Compare, e.g., infra app. F, at tbl.F.7 (showing insanity defenses arising in $1.05 \%$ of cases heard by circuit court judges and $0.33 \%$ of cases heard by district court judges), with infra app. E, at tbl.E.1 (showing insanity defenses arising in $0.90 \%$ of cases heard by judges, excluding Maryland district court judges).

${ }_{148}$ Respondents 55,560, 55,674, 55,810, and 55,850.

149 Respondents 55,568, 55,695, and 55,764.

${ }^{150}$ Respondent 55,789.

${ }^{151}$ Respondent 55,888.

${ }^{152}$ Respondent 55,568. 
Taken together, these comments offer some evidence that the role of criminal defenses is shifting from the traditional formal notion of pleadings in court to an informal negotiation where the relative strength of the particular claim has a proportional influence on the outcome of a plea bargain. Assuming a defendant pleading guilty to a crime is, to some extent at least, "guilty," then the defenses seem to have a justice-promoting effect on making the punishment suit the crime. $^{153}$

\section{CONCLUSION}

This survey provides information on the use and success rate of a number of defenses that are infrequent but not irrelevant. The data suggest interesting correlations between statutory formulation and success rates, lend credence to the stories of an overwhelmed criminal justice system, and provide insights into how the system is adapting at the ground level to accommodate an ever increasing burden. As a result, this survey raises questions regarding how the law should change to meet the challenges of the modern world, particularly in the areas of statue of limitations, double jeopardy, and Sixth Amendment false identification claims where new technology has undermined some of the traditional justifications for the defenses. While the six criminal defenses studied each showed low occurrence rates, their existence and use is notable and important to the discussion of the role of the defenses in modern criminal law. Constitutional defenses arise fairly frequently and, while their ultimate success in exonerating a defendant is low, the administrative burden of handling so many motions may be significant. As is well known, plea negotiations play an extremely important role in the American criminal justice system, and the comments of the survey respondents indicate that the criminal defenses and constitutional claims studied have an impact on the outcome of plea negotiations. As discussed in Part I of this Comment, although this study cannot be generalized to other states and is subject to potential biases among respondents, the results do provide a first look at a number of areas that have not received significant empirical

${ }^{153}$ Rachel E. Barkow, Recharging The Jury: The Criminal Jury's Constitutional Role in an Era of Mandatory Sentencing, 152 U. PA. L. REV. 33, 95-100 (2003) (arguing that pleas approximate trial outcomes but that sentencing guidelines have upset the process). But see Stephanos Bibas, Plea Bargaining Outside the Shadow of Trial, 117 HARV. L. REv. 2463, 2464 (2004) (rejecting the argument that pleas approximate trial outcomes, arguing that various externalities are the most important factors in determining what pleas are offered, and concluding that this effect results in a miscarriage of justice). 
[Vol. 153: 1709

attention. The development of scientific methods and quantitative analysis is one of the greatest achievements of modern society; the law should be careful not to ignore them. 


\section{APPENDIX}

The following descriptions are intended to clarify the presentation of results in the tables that follow. As discussed in this Comment, these results convey information on the use of the studied defenses among the respondents in the states surveyed. The results should not be viewed as representative of any other population.

\section{Description of Terms Used:}

Regarding All Tables:

" $n$ "

Reported " $n$ " values represent the total number of respondents who provided answers to a given question. Respondents sometimes answered only two or three of the four parts of the question; hence, there is a slightly different response rate for each question.

\section{"Median"}

The median represents the median answer given by all respondents to a particular question.

Regarding the Tables on Criminal Defenses and Constitutional Claims:

Respondents were asked to report the number of cases during the previous twelve months in which they saw each defense or constitutional claim. These numbers were aggregated and converted into percentages based on the total number of cases seen by all defendants.

\section{"Offered"}

In how many criminal cases was the following defense raised?

The percentages reported were calculated by dividing all reported occurrences of the defense by the total number of cases seen by respondents who responded to the question. 


\section{"Successful"}

In how many of these cases was the claim successful?

The percentages reported were calculated by dividing all reported successful occurrences of the defense by the total number of cases seen by respondents who responded to the question.

It is possible that a defendant can succeed on a constitutional evidentiary claim on one piece of evidence but be convicted based on other evidence. Because of this, for the three constitutional claims, the question stem was altered to read "Dismissal/acquittal/nonprosecution under $[\mathrm{X}$ amendment $]$." This change was made so that respondents would equate success of the motion with the case being dismissed or person acquitted rather than with the evidence being excluded.

\section{"Success Rate"}

The percentages reported were calculated by dividing the total reported number of times a defense was successful by the total reported number of times the defense was offered.

\section{"Bypassed"}

In how many cases could the claim have been offered but was not?

The percentages reported were calculated by dividing all reported occurrences of the defense being bypassed by the total number of cases seen by respondents who responded to the question.

\section{"Not Prosecuted"}

In how many instances was a case not prosecuted, or a charge dropped in anticipation of the defense?

The percentages reported were calculated by dividing all reported occurrences of the defense resulting in nonprosecution by the total number of cases seen by respondents who responded to the question.

Regarding the Tables on Plea Bargains:

Respondents were asked to estimate the percentage, rather than the raw number, of their cases that involved plea bargains. In order to compare results among respondents, the responses were converted into raw numbers based on the total number of cases seen by a respondent. The percentages reported were then calculated by dividing 
all reported occurrences of plea bargains by the total number of cases seen by respondents who responded to the question.

\section{"Offered"}

This represents the percentage of cases in which "a plea bargain was offered" to a defendant.

\section{"Accepted"}

This represents the percent of cases in which "a plea bargain was accepted" by a defendant.

The following three categories represent the outcome of the accepted plea bargains. The percentages reported were calculated by dividing the number of pleas in the appropriate category (i.e., nonprosecution, reduced sentence, or reduced charge) by the number of pleas accepted. Thus, if 90 out of 100 plea offers were accepted, and 9 of the accepted pleas resulted in nonprosecution, then the reported nonprosecution rate would be $10 \%$. As noted in this Comment, the results of these three outcomes add up to more than 100\%, indicating that there was overlap between the categories.

\section{"Nonprosecution"}

This represents the number of cases in which an accepted plea "resulted in nonprosecution." This question was formulated broadly so as to include any type of plea that led to nonprosecution, including immunity, probation, work release, etc.

\section{"Reduced Sentence"}

This represents the number of cases in which an accepted plea "resulted in a reduced sentence."

\section{"Reduced Charge"}

This represents the number of cases in which an accepted plea "resulted in a reduced charge." 
APPENDIX A: SAMPLE SURVEY QUESTIONNAIRE 


\section{CRIMinal Defense Frequency Questionnaire}

i. Your position: Judge Prosecutor Defense Counsel

ii. Do your cases primarily come from areas that are: Urban

iii. Estimated total number of criminal cases you handled in the last 12 months:

iv. Estimate of total number of criminal cases in your locale in the past 12 months: $* * *$

For each of the defenses below, you will be asked to estimate, during the past 12 months,

A. in how many criminal cases was the following defense raised?

B. in how many of these cases was it successful?

C. in how many cases could it plausibly have been offered but was not?

D. in how many instances was a case not prosecuted, or a charge dropped, because this defense would have been offered?

Please answer column one (I) based on cases in which you were personally involved, and column two (II) based on cases you were aware of, but not involved with, in your locale.

DEFENSE: DURING THE PAST 12 MONTHS HOW MANY TIMES HAVE THE FOLLOWING CRIMINAL DEFENSES ARISEN?

\section{Entrapment:}

A. Defense was raised?

B. Defense was successful?

C. Defense could have been offered but was not?

D. Charge not prosecuted/dropped in anticipation of defense?

\section{Statute of Limitations:}

A. Defense was raised?

B. Defense was successful?

C. Defense could have been offered but was not?

D. Charge not prosecuted/dropped in anticipation of defense?

3. Insanity:

A. Defense was raised?

B. Defense was successful?

C. Defense could have been offered but was not?

D. Charge not prosecuted/dropped in anticipation of defense?

\section{Diplomatic Immunity:}

A. Defense was raised?

B. Defense was successful?

C. Defense could have been offered but was not?

D. Charge not prosecuted/dropped in anticipation of defense?

5. Double Jeopardy:

A. Defense was raised?

B. Defense was successful?

C. Defense could have been offered but was not?

D. Charge not prosecuted/dropped in anticipation of defense?
(I) \# OF YOUR OWN CASES

(II) \# OF OTHER CASES IN YOUR LOCALE 


\section{Reasonable mistake of law:}

A. Defense was raised?

B. Defense was successful?

C. Defense could have been offered but was not?

D. Charge not prosecuted/dropped in anticipation of defense?

\section{Dismissal/acquittal/non-prosecution under $4^{\text {th }}$} Amendment arrest, search \& seizure exclusionary rule:

A. Defense was raised?

B. Defense was successful?

C. Defense could have been offered but was not?

D. Charge not prosecuted/dropped in anticipation of defense?

\section{Dismissal/acquittal/non-prosecution under $5^{\text {th }}$}

Amendment interrogations \& confessions exclusionary

rule:

A. Defense was raised?

B. Defense was successful?

C. Defense could have been offered but was not?

D. Charge not prosecuted/dropped in anticipation of defense?

9. Dismissal/acquittal/non-prosecution under $6^{\text {th }}$ Amendment identification procedures or right to counsel exclusionary rule:

A. Defense was raised?

B. Defense was successful?

C. Defense could have been offered but was not?

D. Charge not prosecuted/dropped in anticipation of defense?

10. Plea Bargain: Percentage of cases in which

A plea bargain was offered?

A plea bargain was accepted?

A plea bargain resulted in non-prosecution?

A plea bargain resulted in reduced sentence?

A plea bargain resulted in reduced charge?

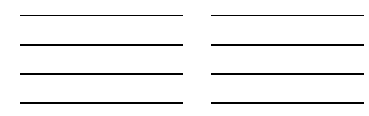

If you would like to comment on any of the above, offer anecdotal stories, or other comments, please use the space below or on the back of the survey. Please be sure to specify what defense you are commenting on. 


\section{APPENDIX B: OvERALl SURVEY RESUlts}

The results in Appendix B represent the aggregation of all responses, but exclude responses from the Maryland district court judges. As discussed in Part I of this Comment, the unique jurisdictional grants of Maryland district courts precluded direct comparison of Maryland district court judge results with the results from other courts.

It should be noted that there may be overlap between cases seen by multiple respondents, which may have led to double counting. 


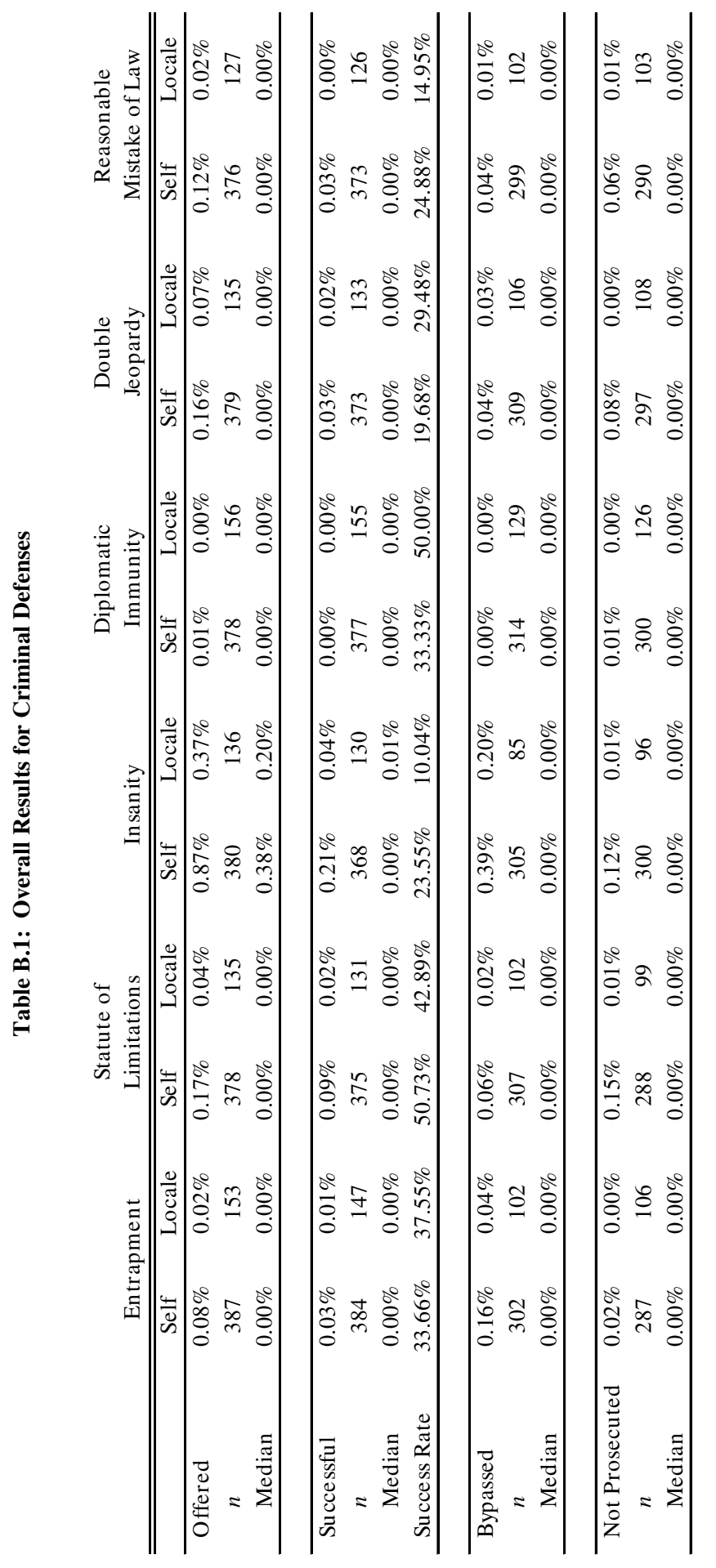



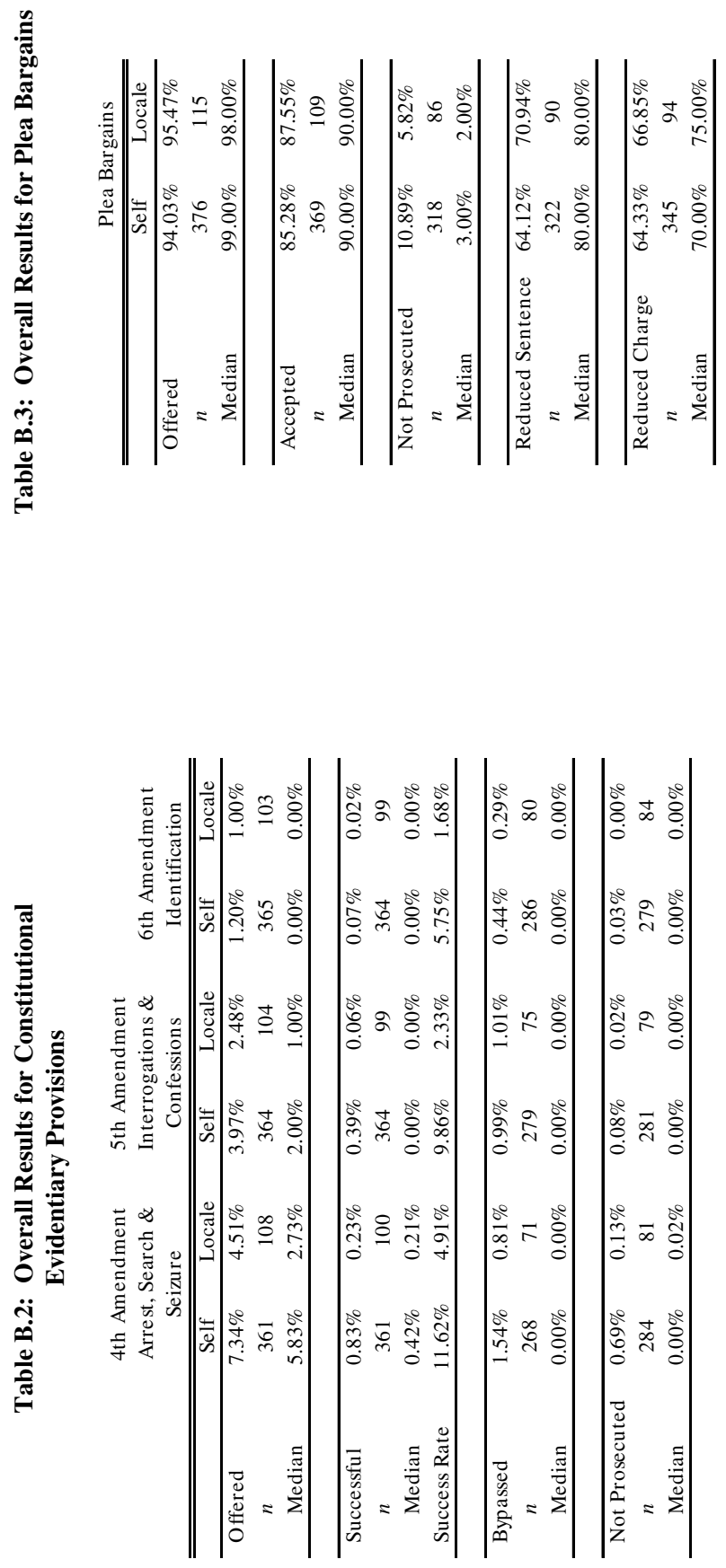


\section{APPENDix C: SuRVEy RESUlts by STATE}

The results in Appendix $\mathrm{C}$ represent the aggregation of all responses within each individual state. Note that no prosecutors in Rhode Island responded to this survey, so the results for Rhode Island are the combined results of judges and defense attorneys. 


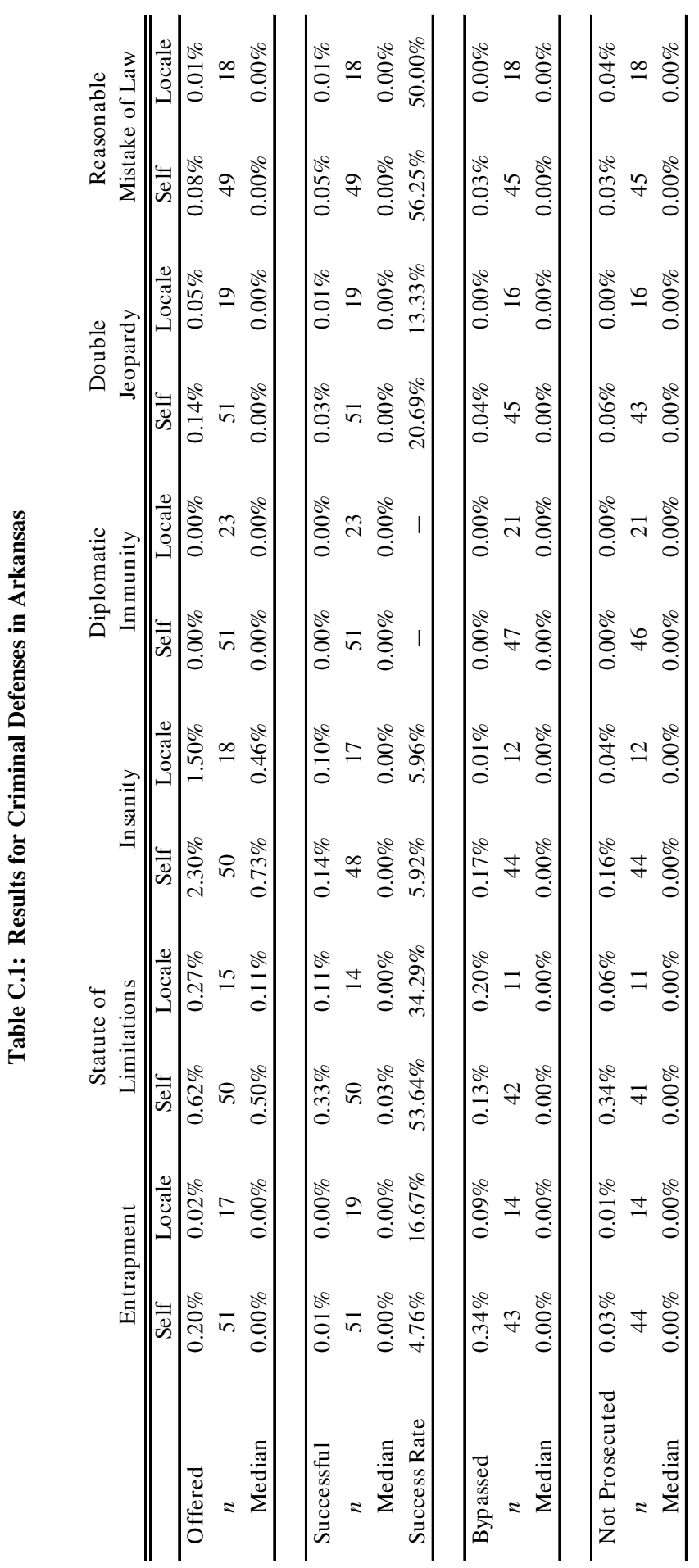



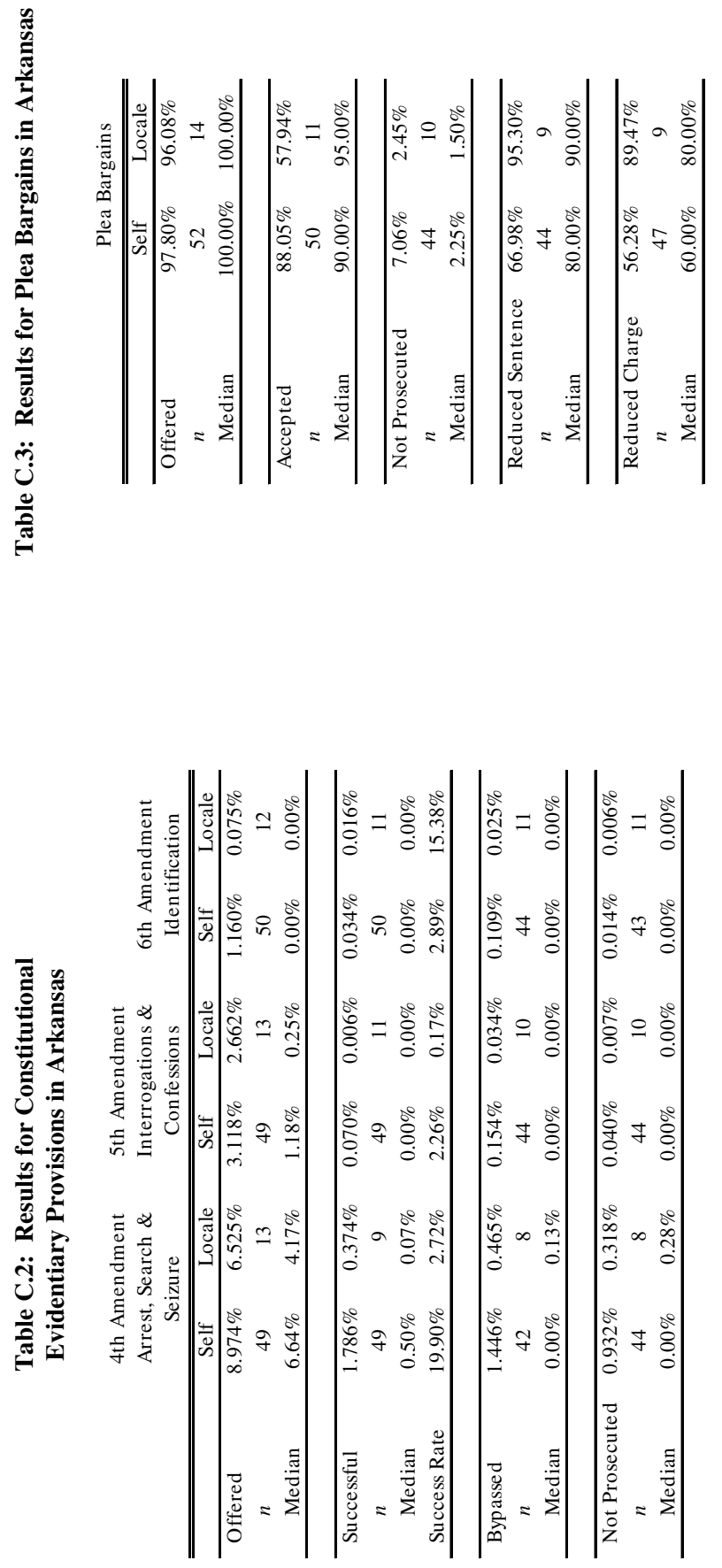


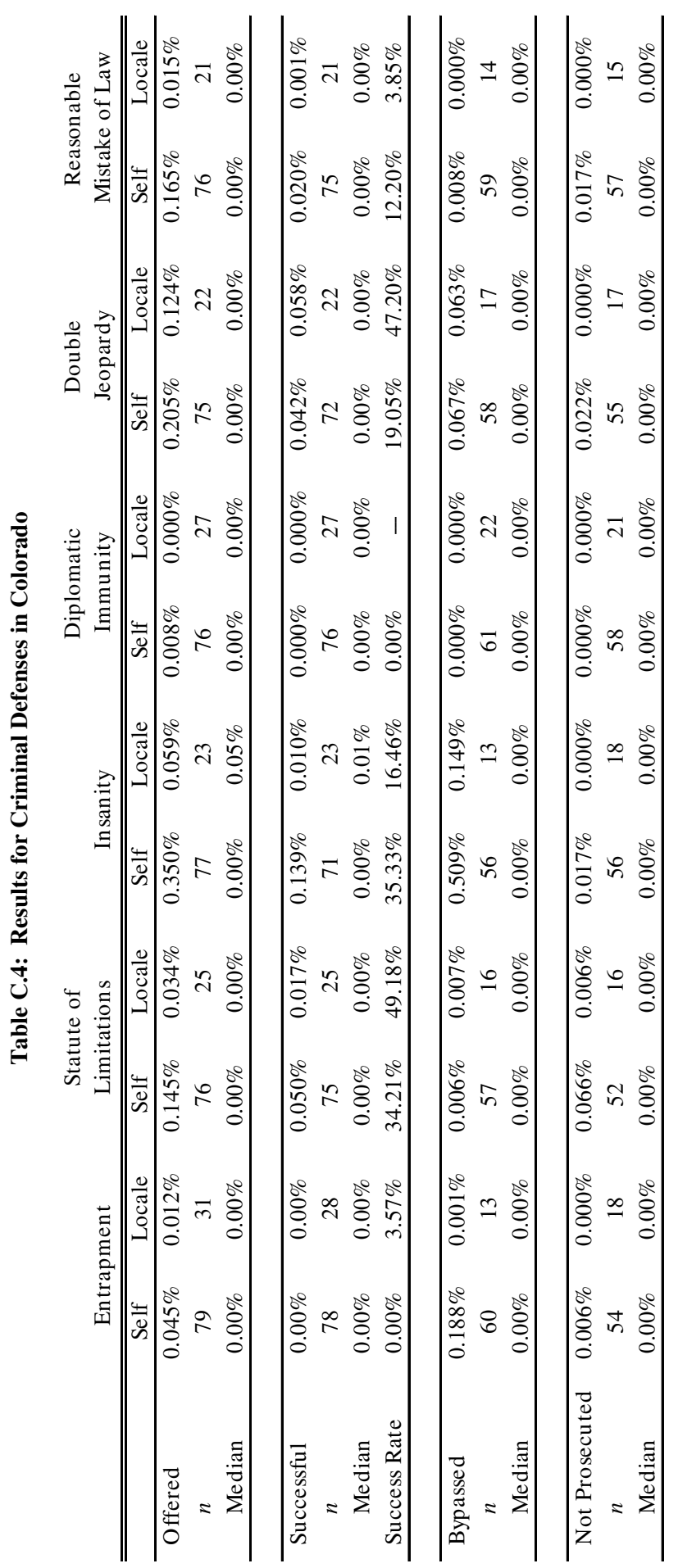



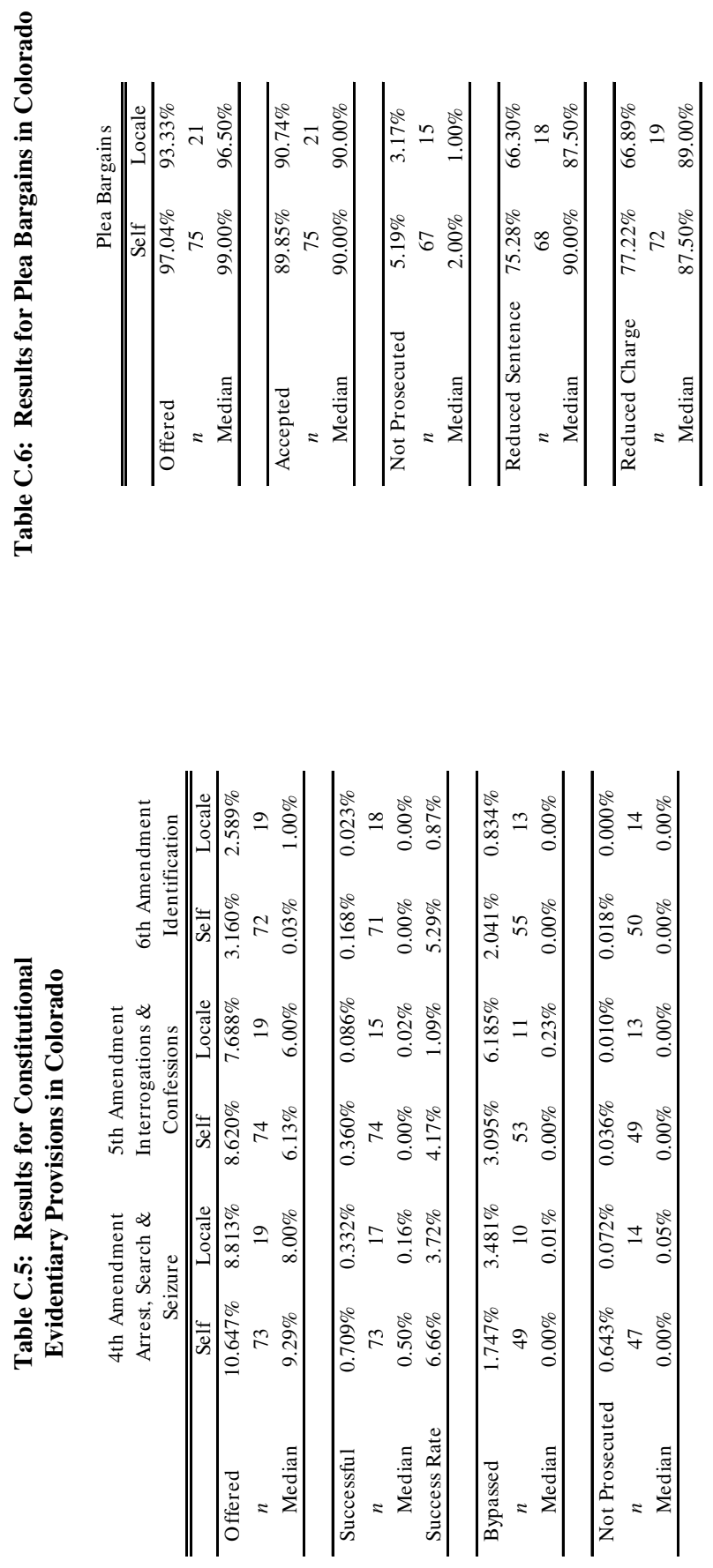


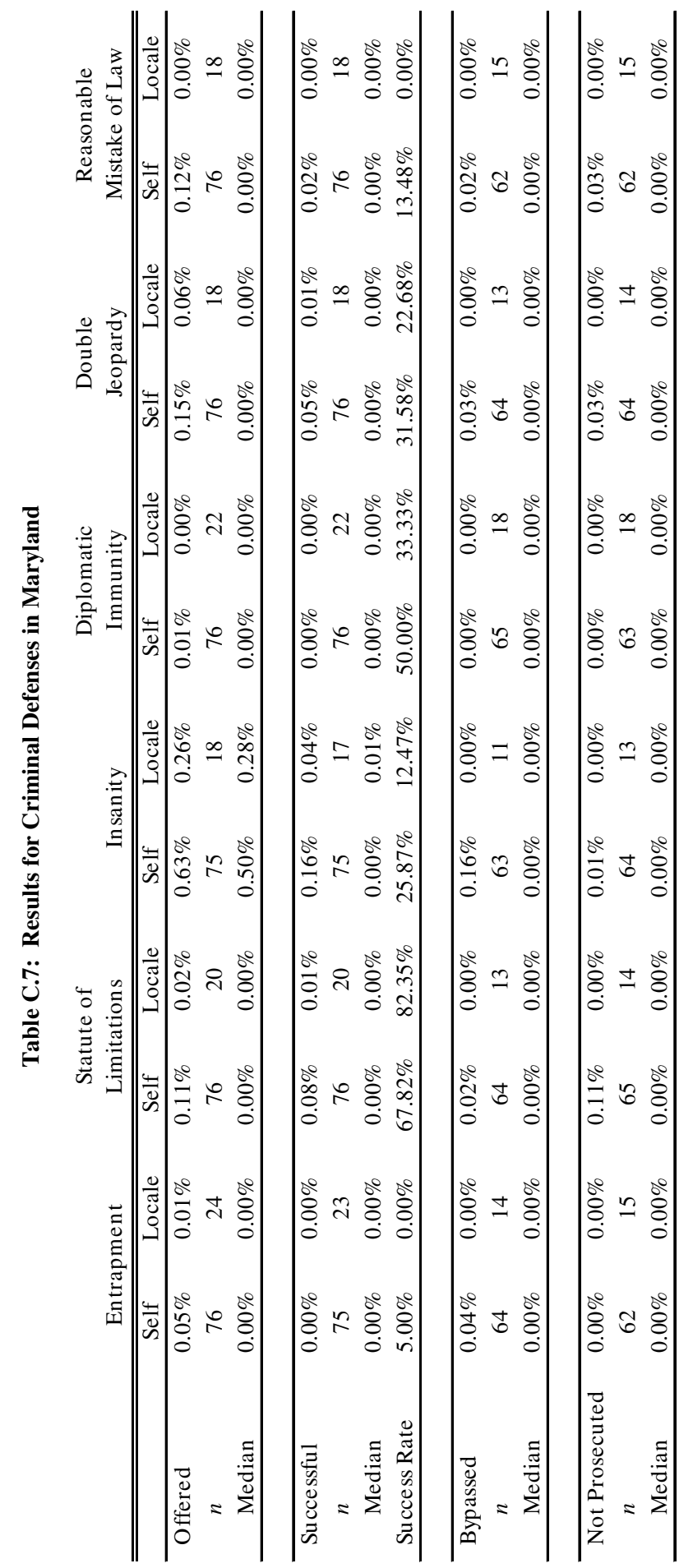



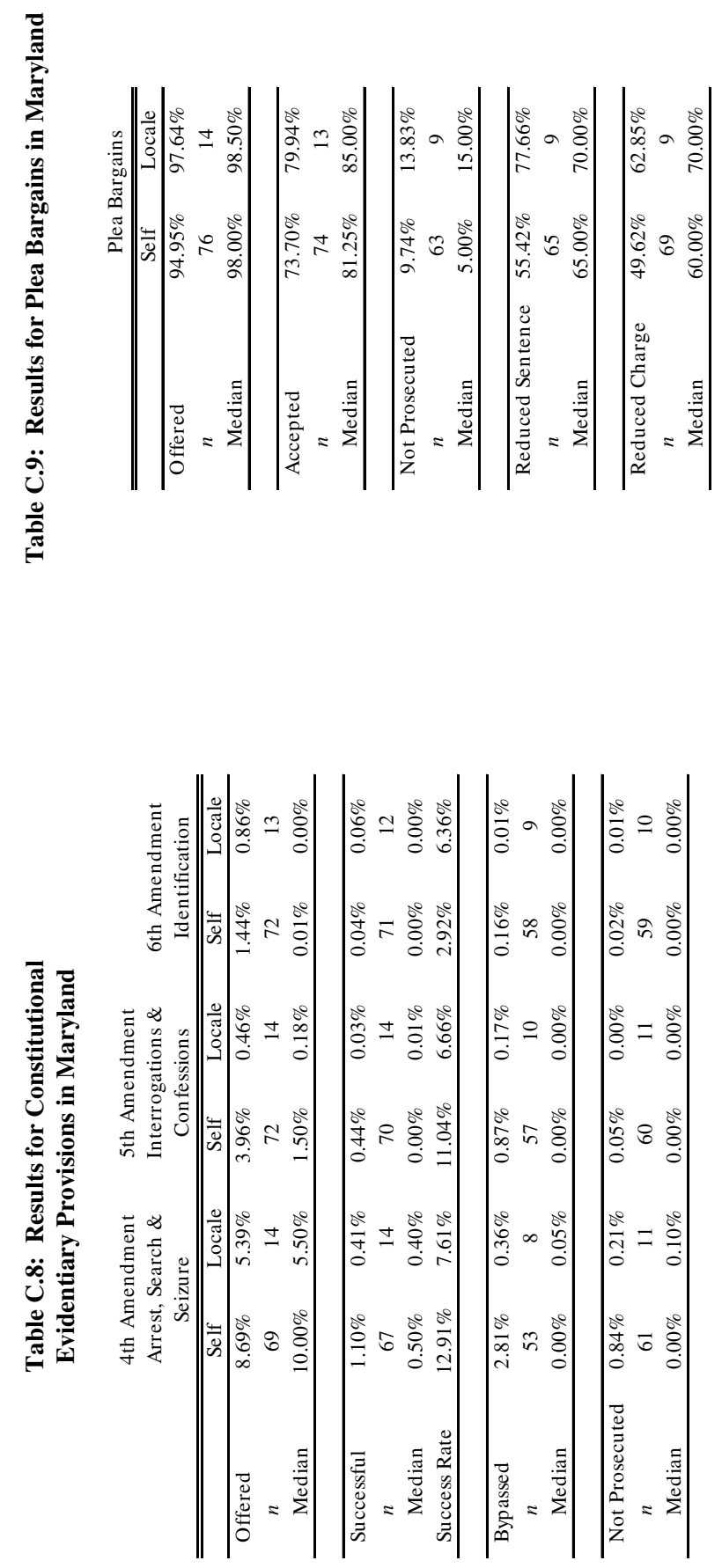


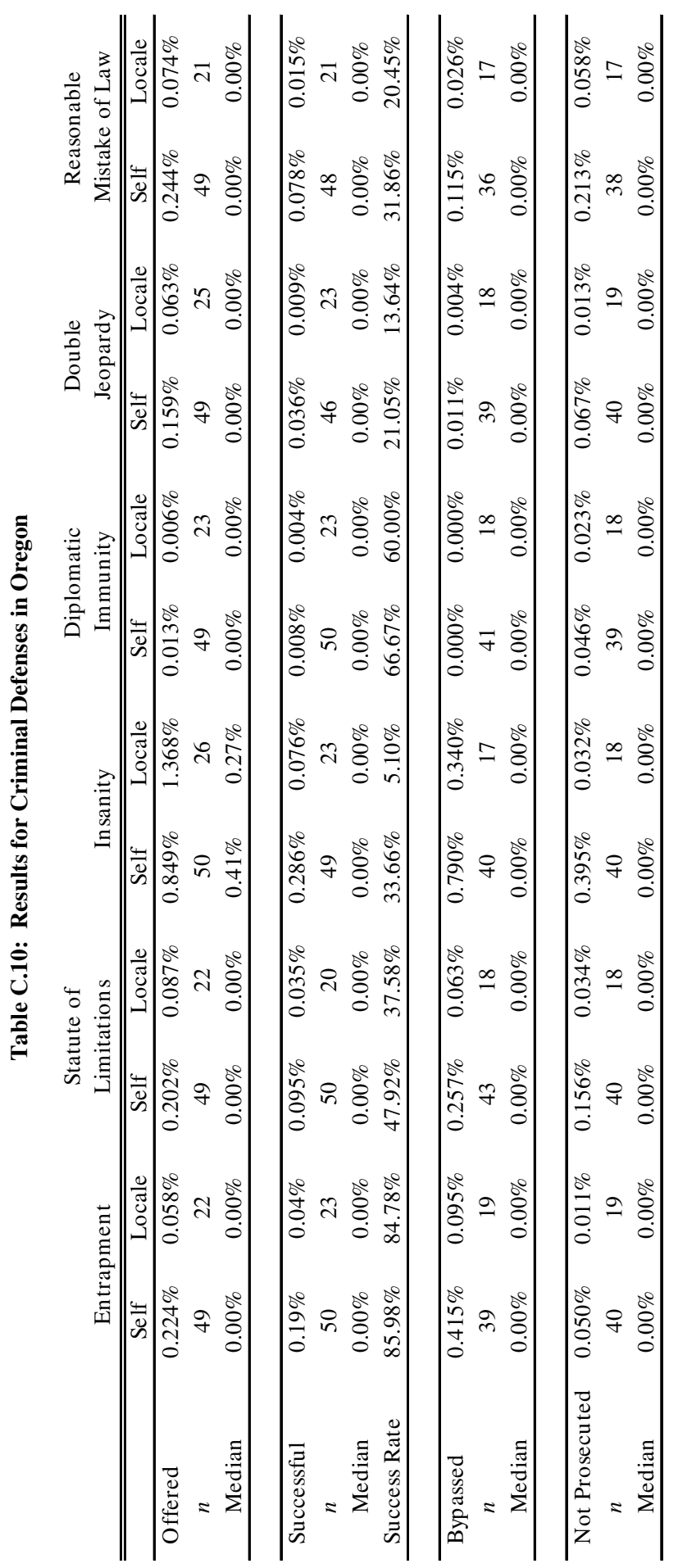



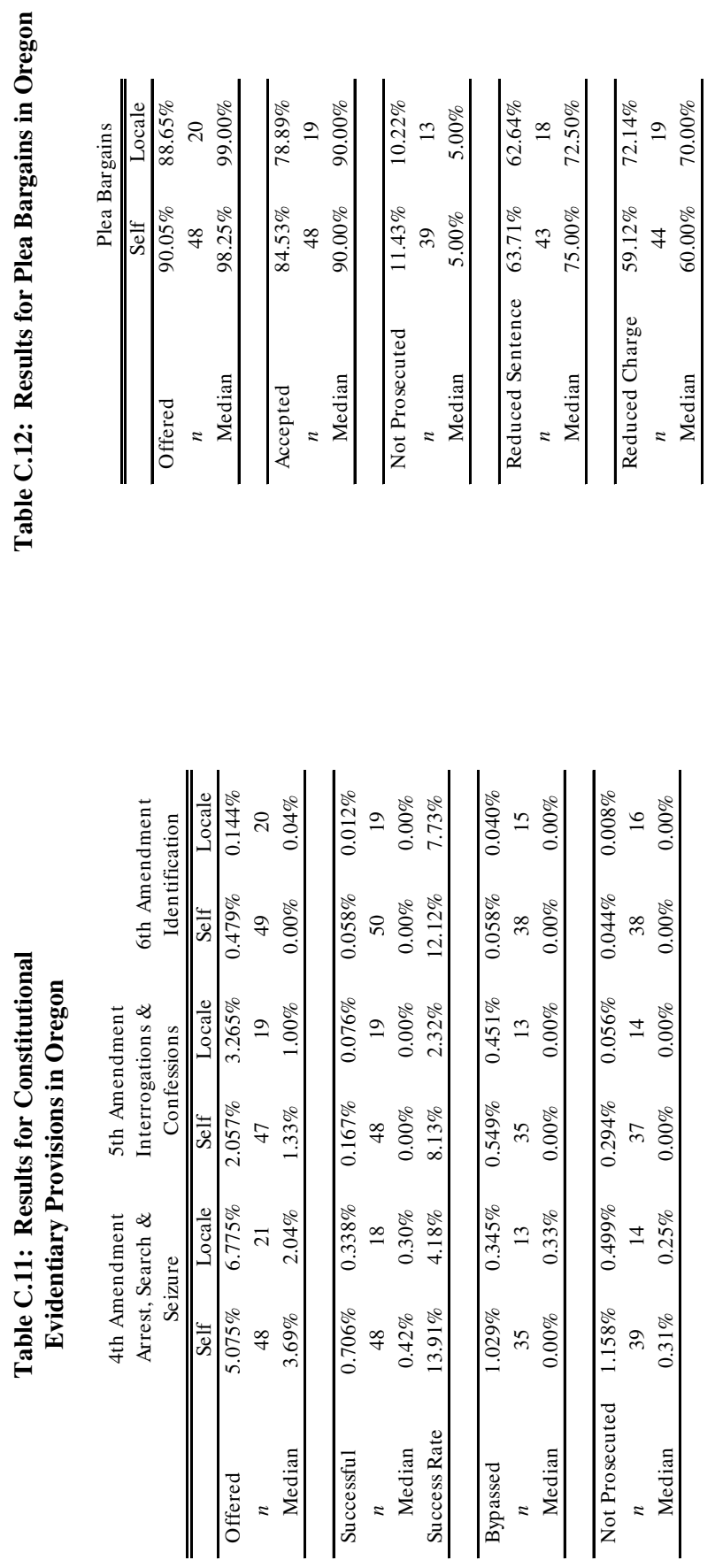


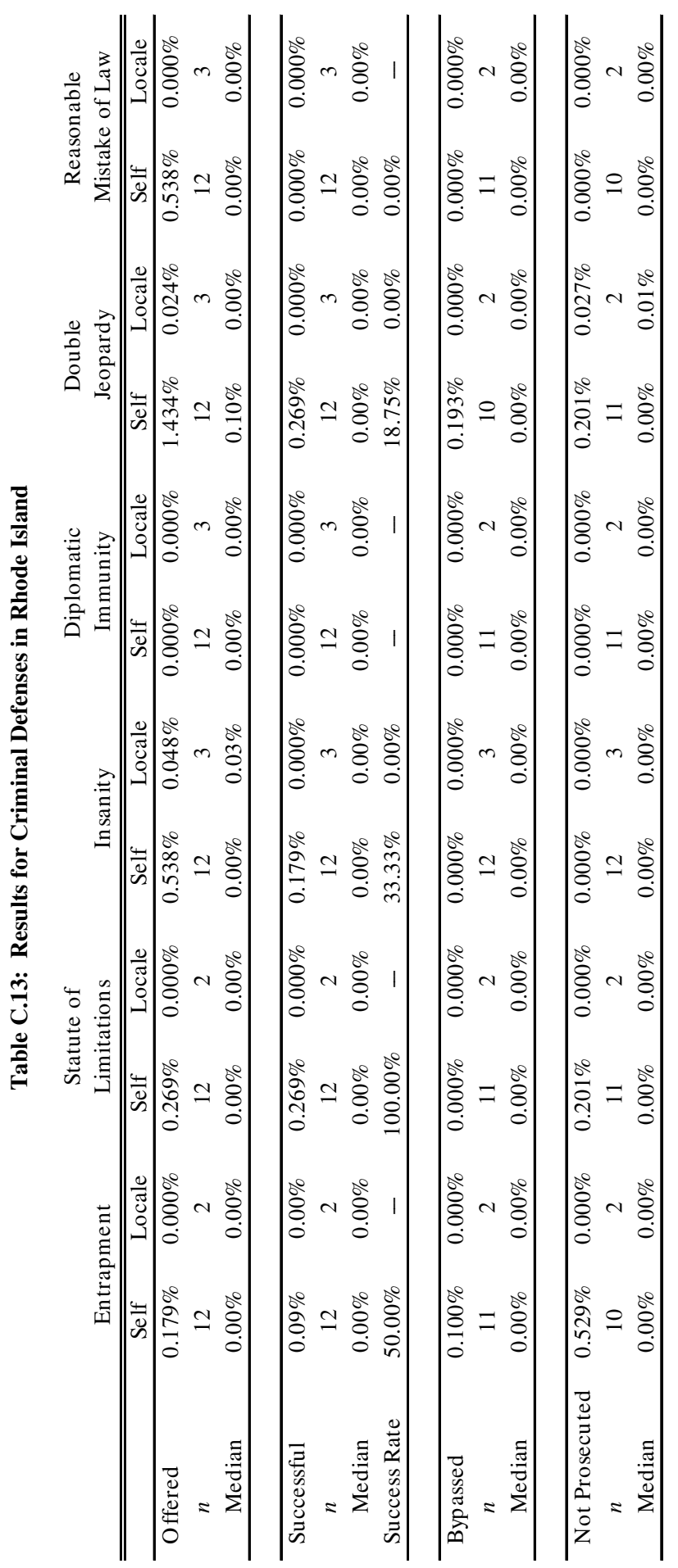



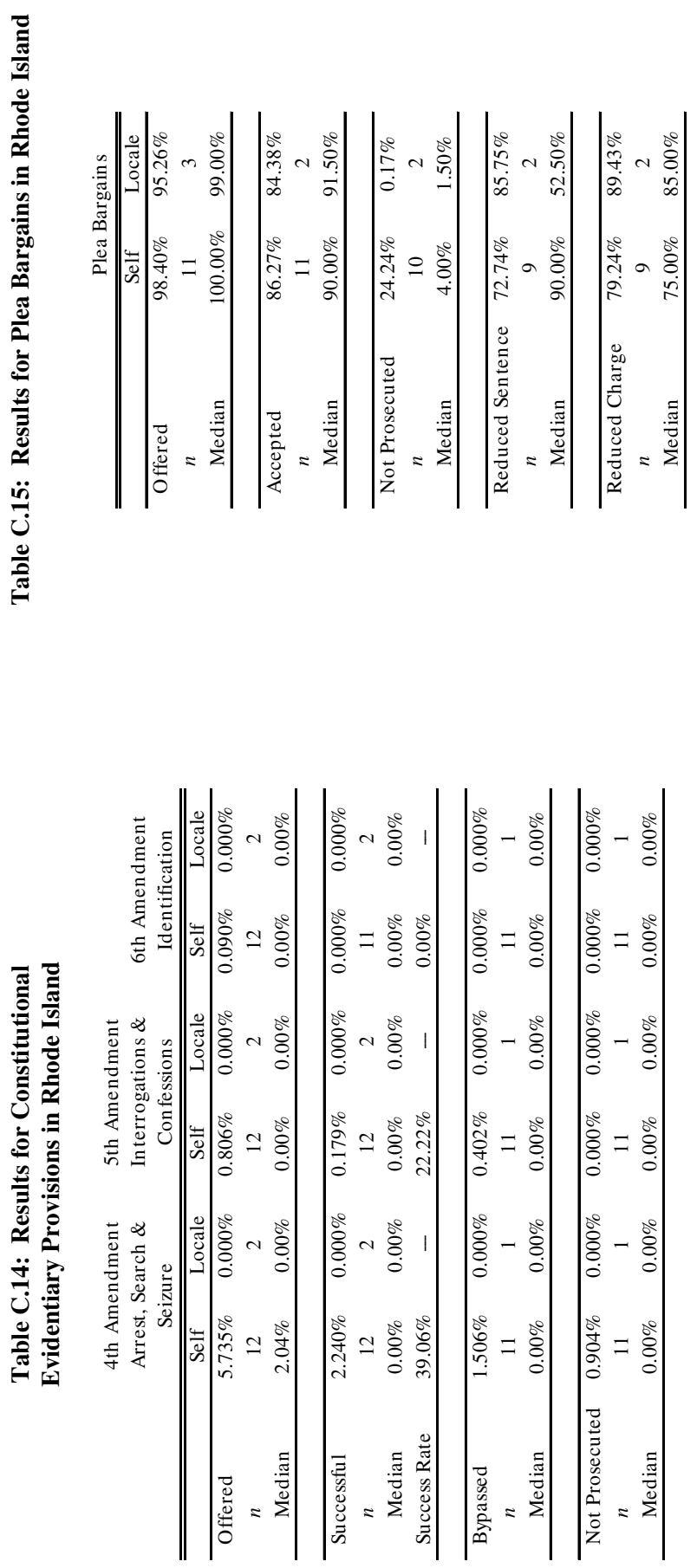


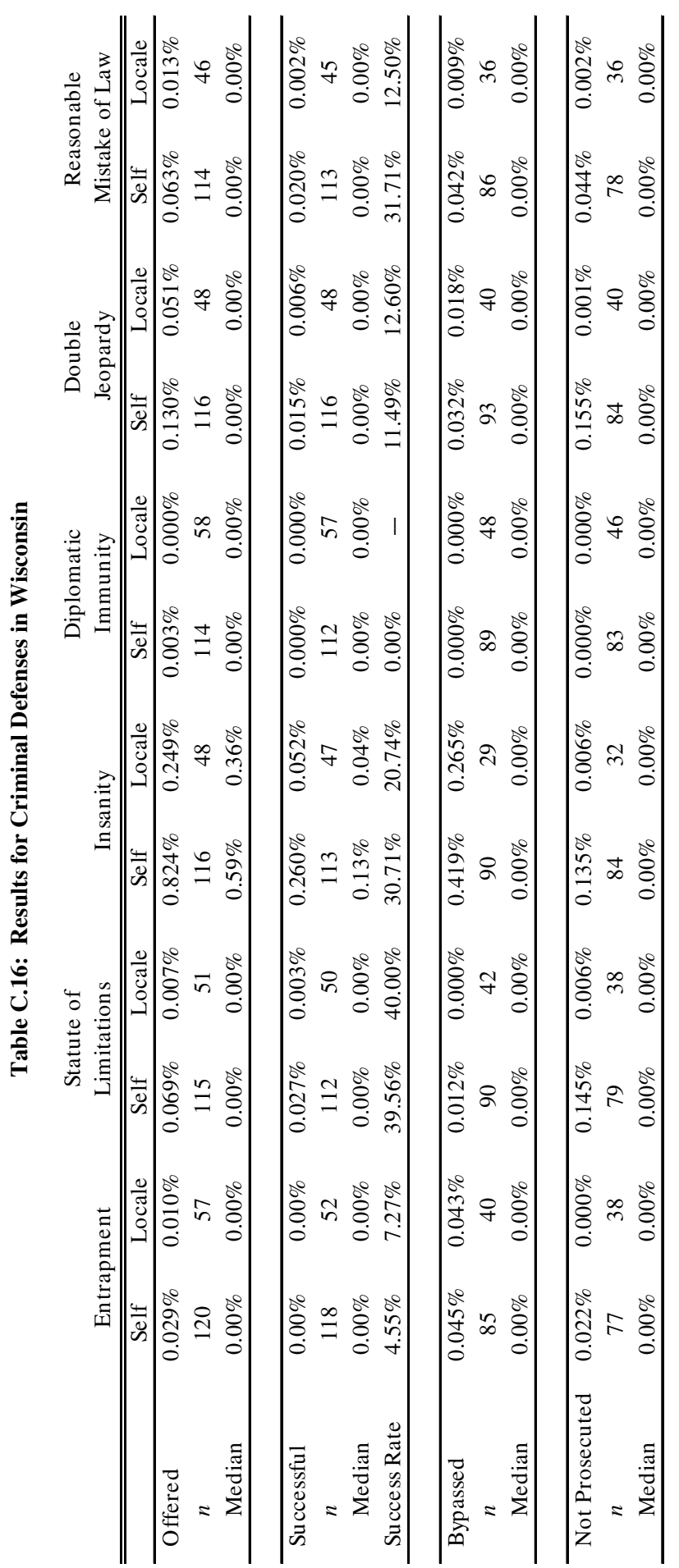



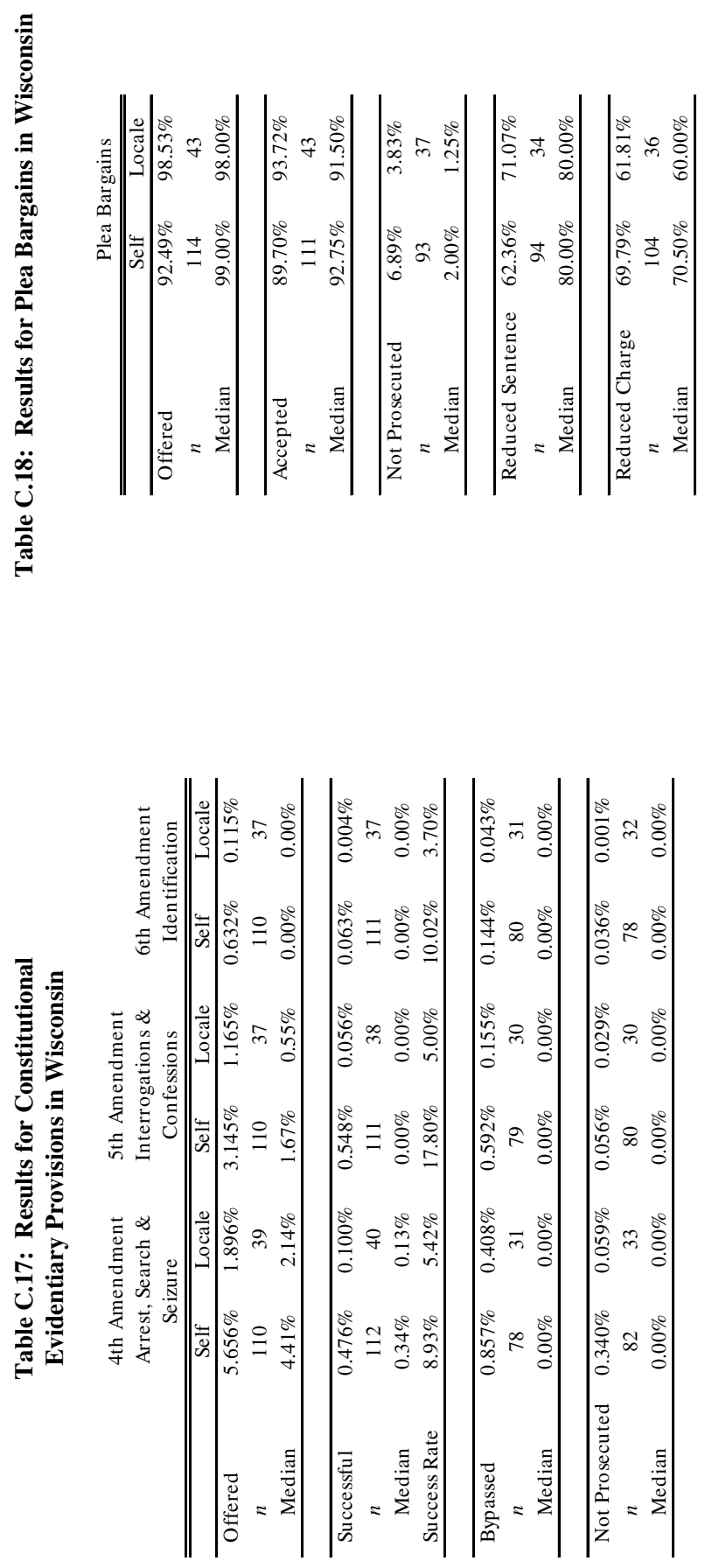


\section{APPENDIX D: SURVEY REsults by AREA TyPe}

The results in Appendix D represent the aggregation of all responses within each individual area type (i.e., Urban, Suburban, Rural, or Mixed). These characterizations are based on the selfreporting of respondents. The tables titled "Urban," "Suburban," and "Rural" contain all respondents who selected one of those categories as describing the area from which most of their cases originate. The tables titled "Mix" contain all respondents who selected more than one of these categories.

It should be noted that there may be overlap between cases seen by multiple respondents, which may have led to double counting. 


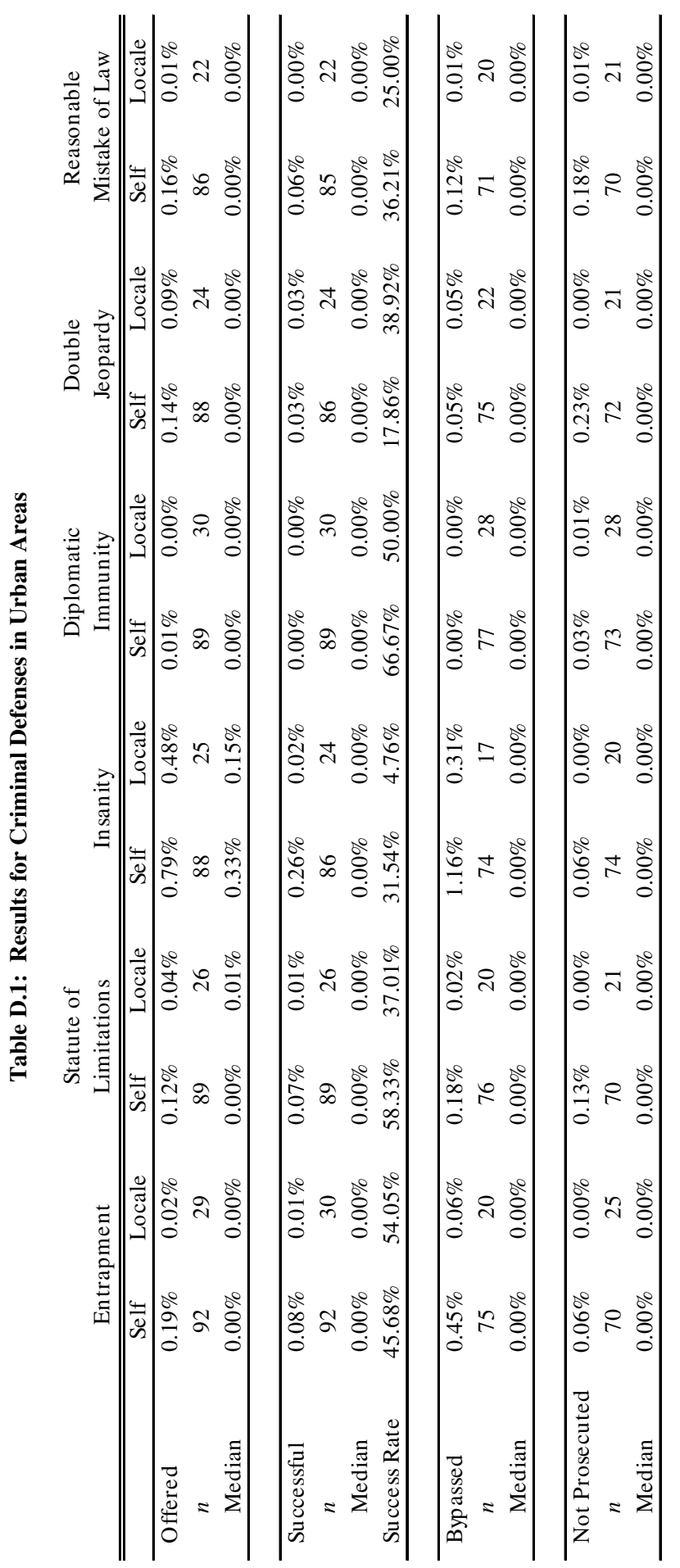



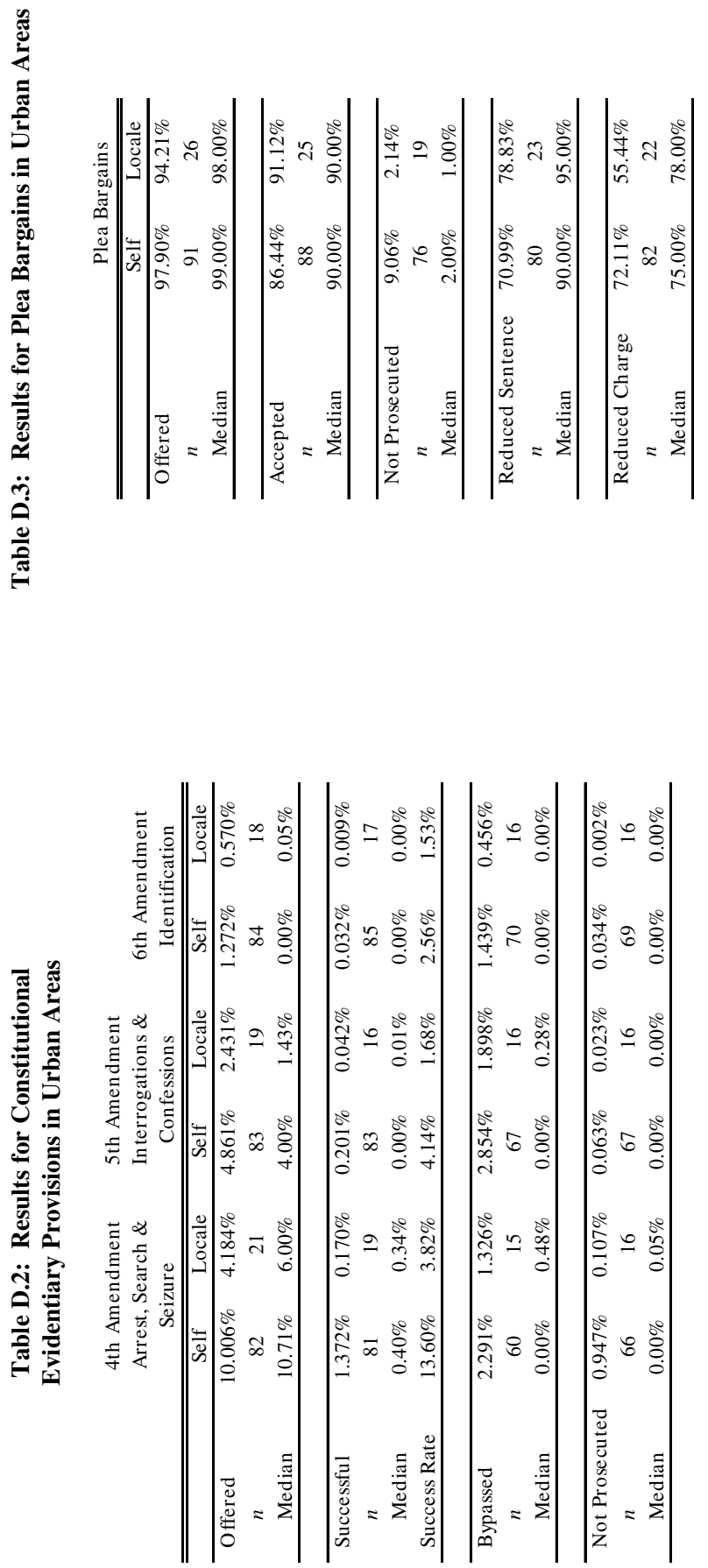


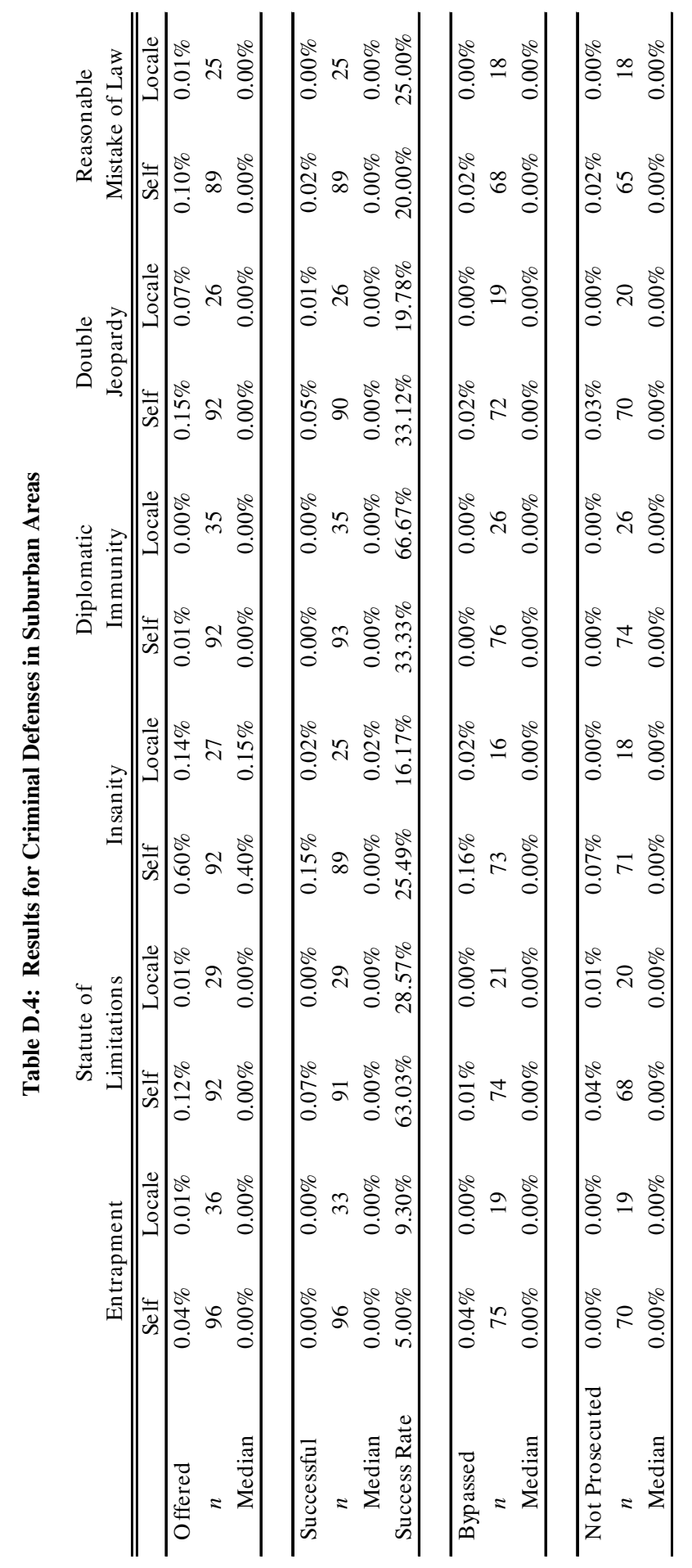



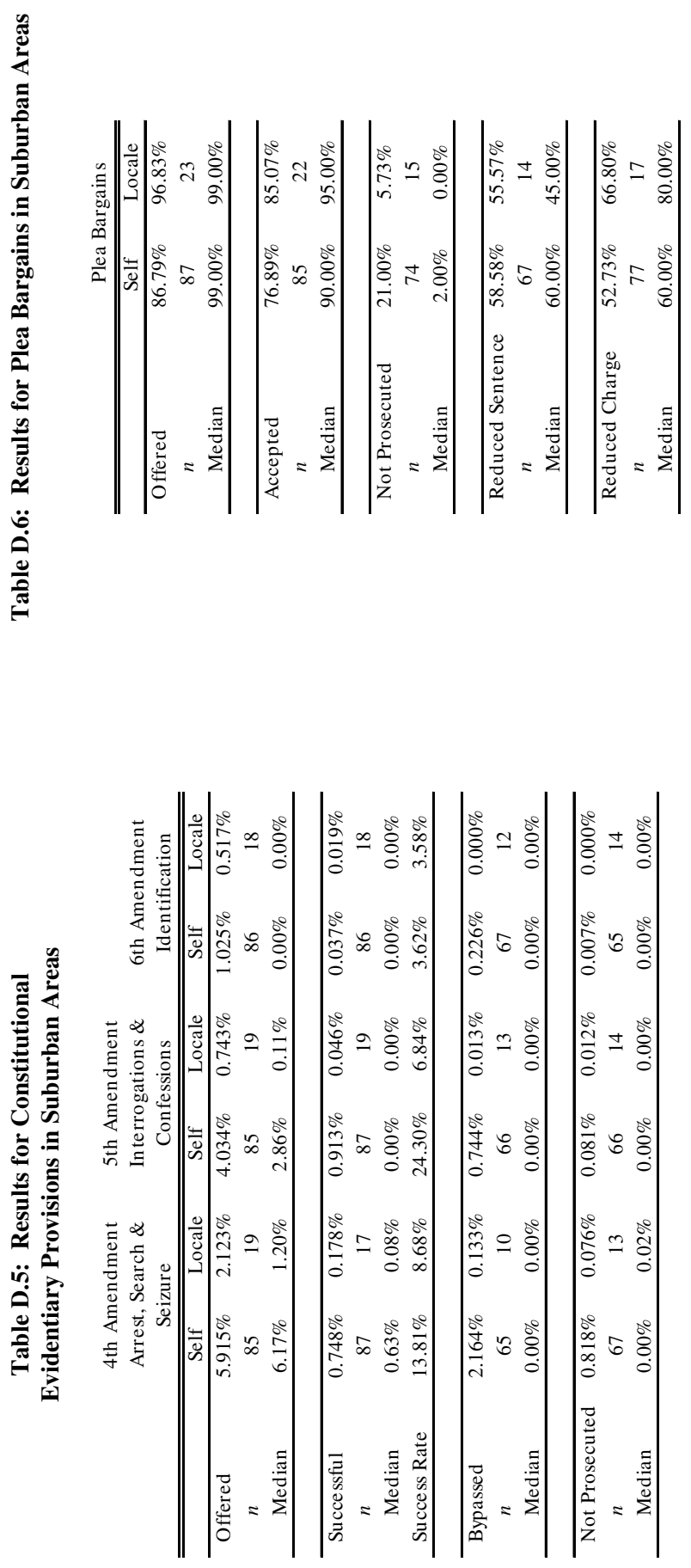


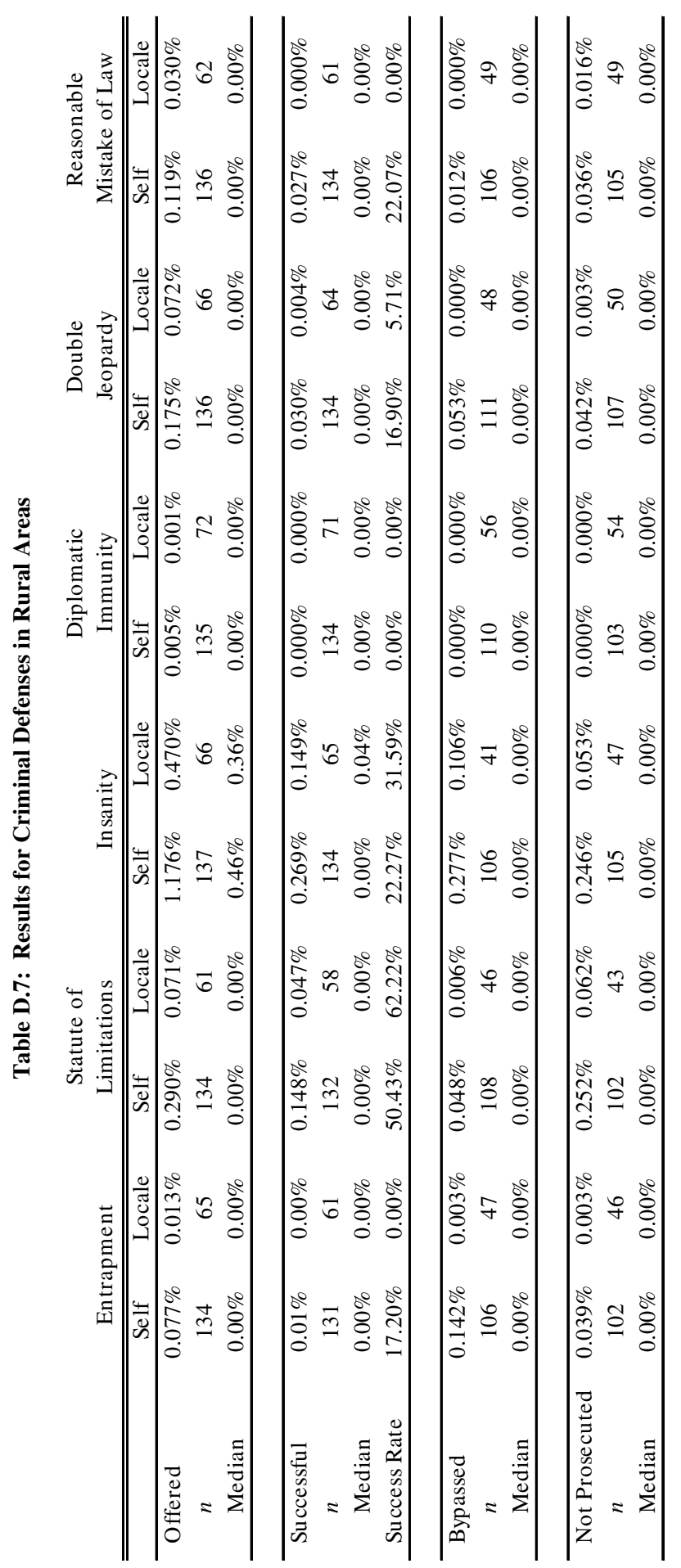



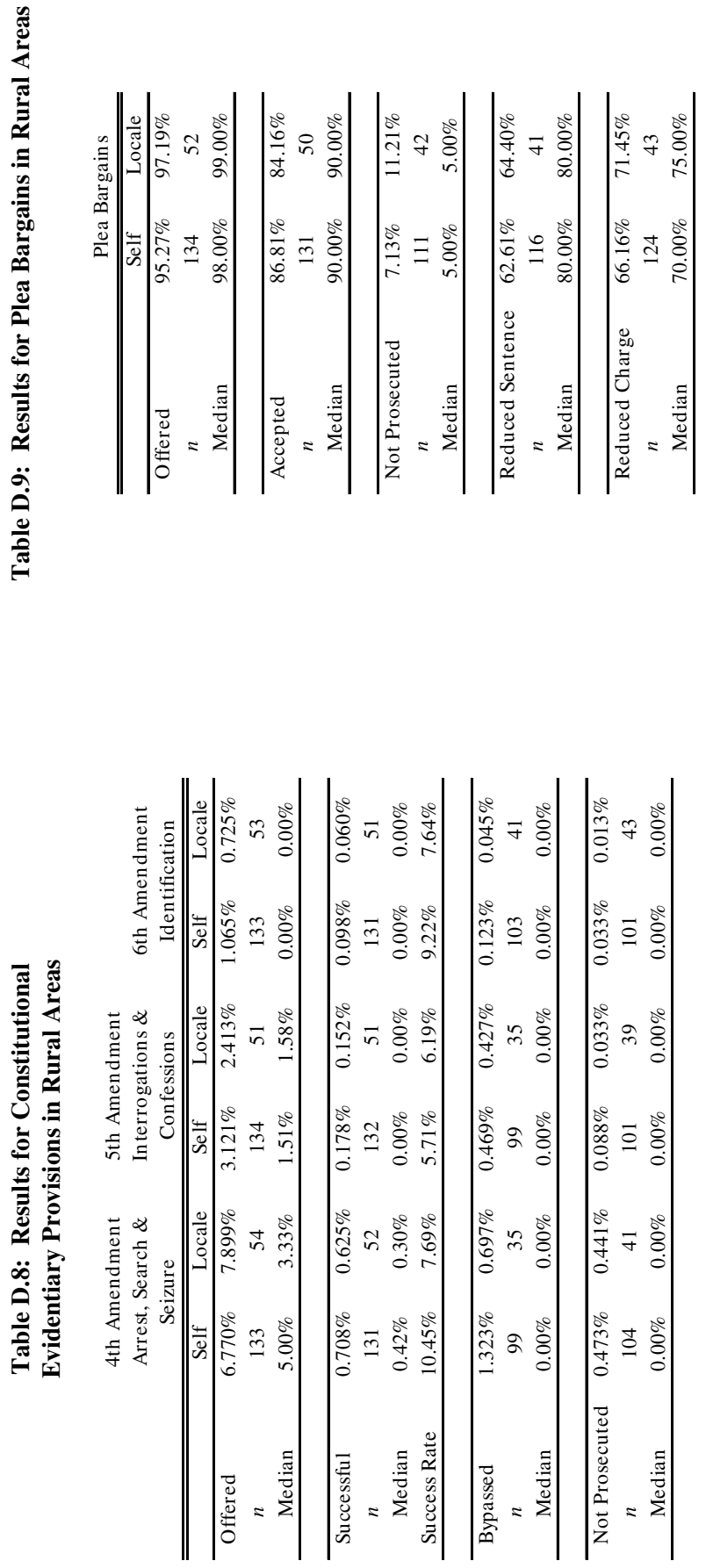


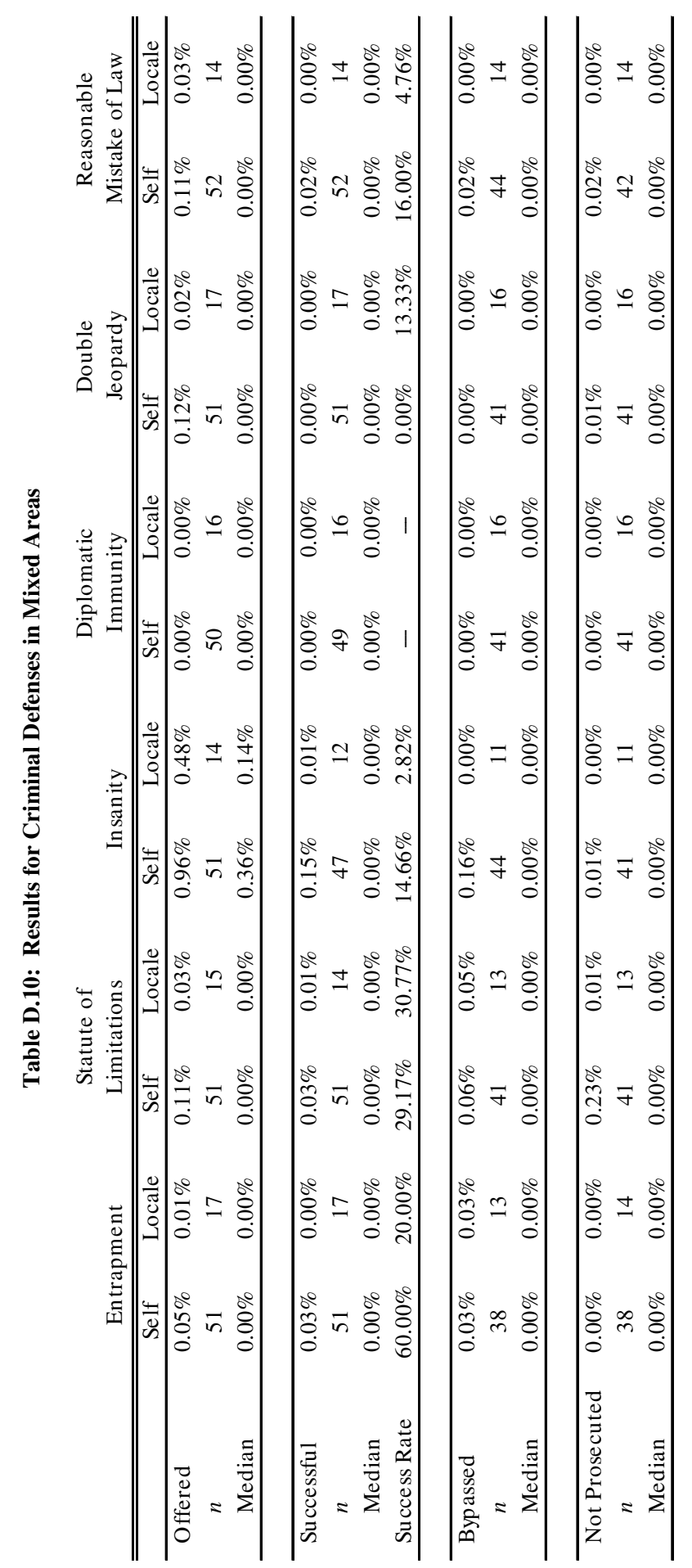



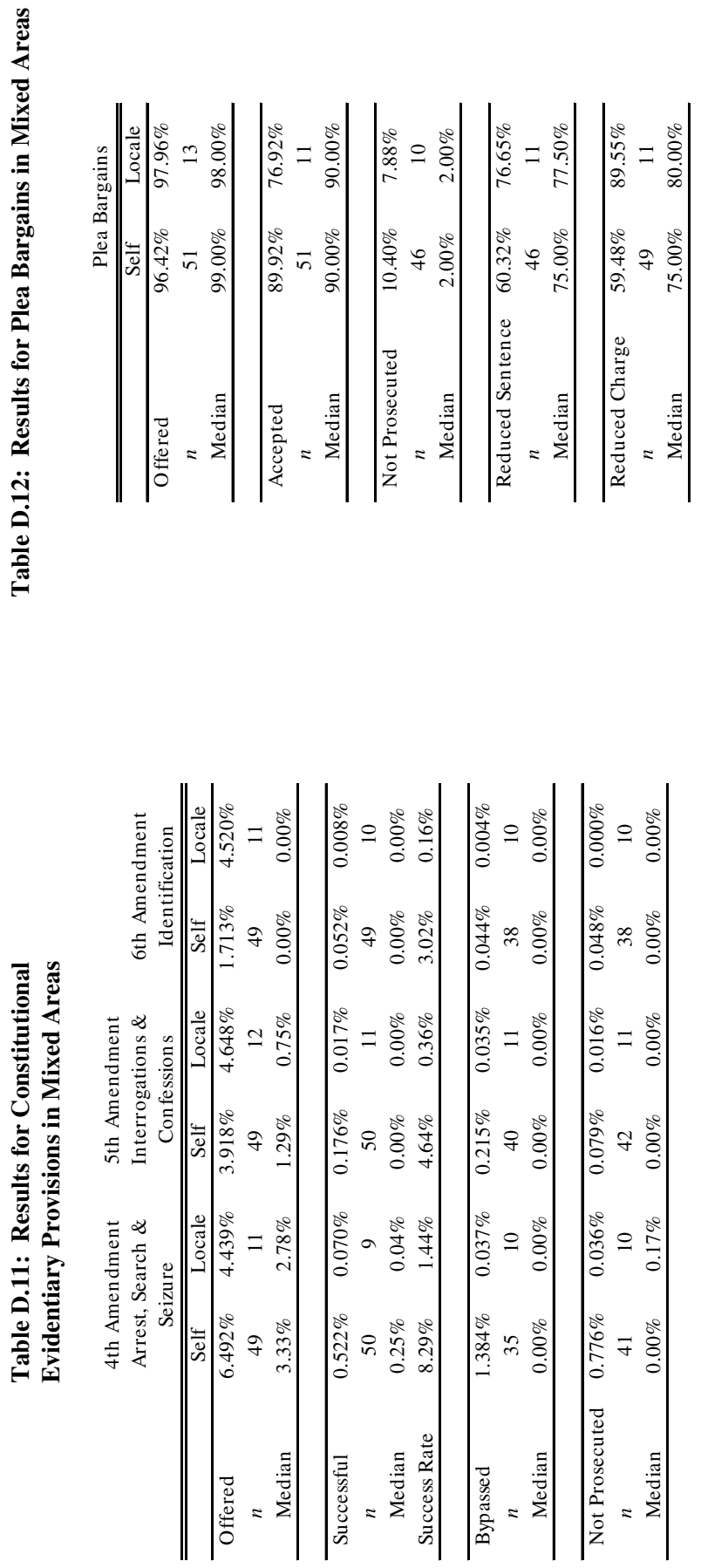
APPENDIX E: SURVEY RESUltS By RESPONDENT TyPE

The results in Appendix E represent the aggregation of responses within each category of respondent (i.e., prosectutor, judge, or defense attorney). 


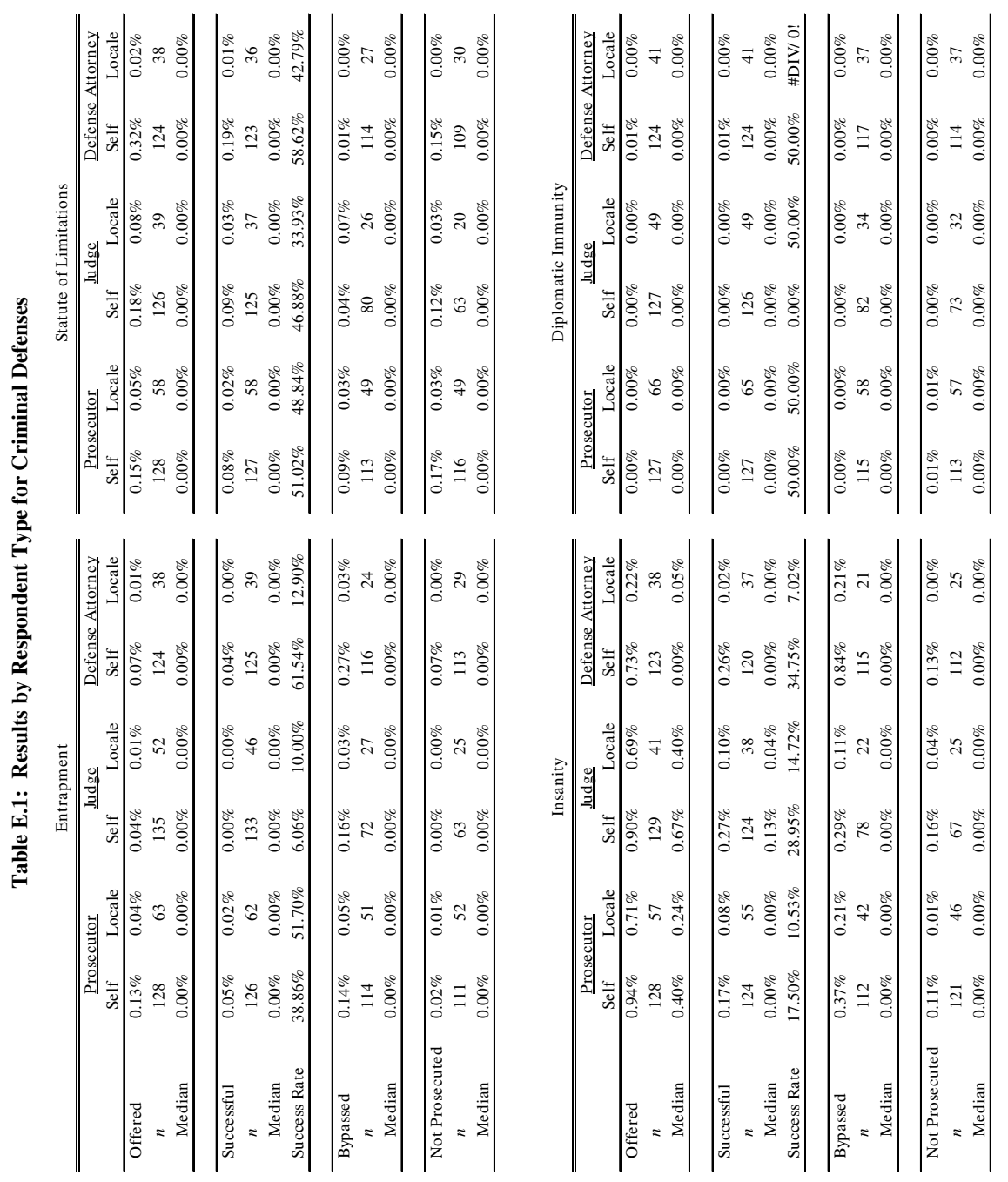




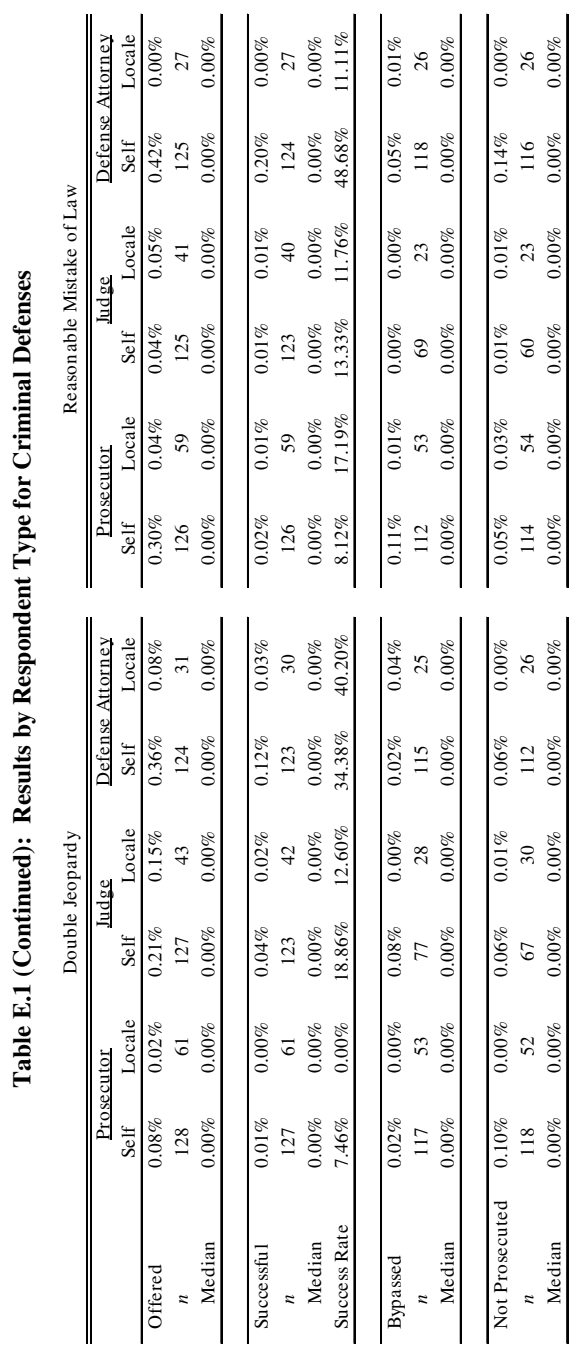




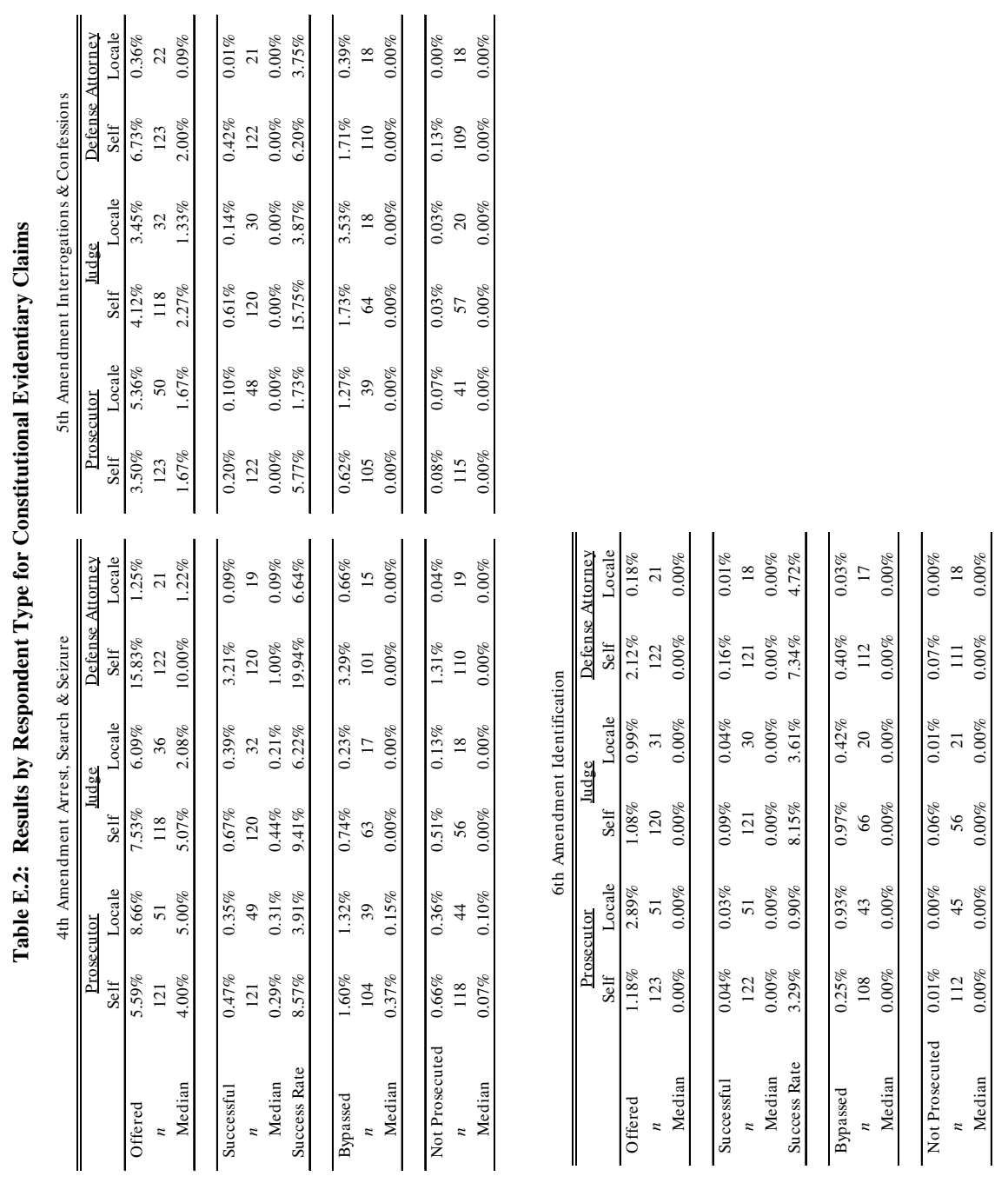




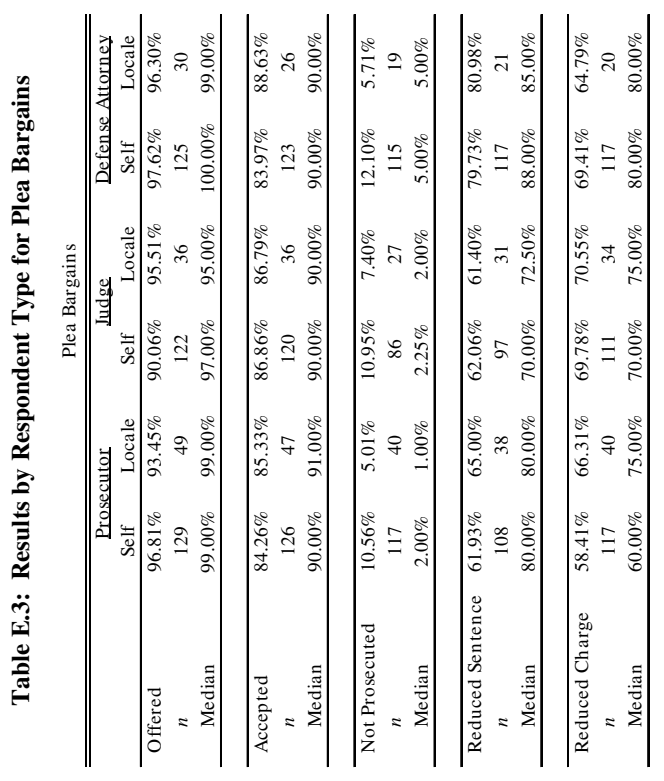


APPENDIX F: SURVEY Results by STATE AND RESPONDENT TyPE

The results in Appendix F represent the aggregation of responses from each individual state within each category of respondent (i.e., prosecutor, judge, or defense attorney). 


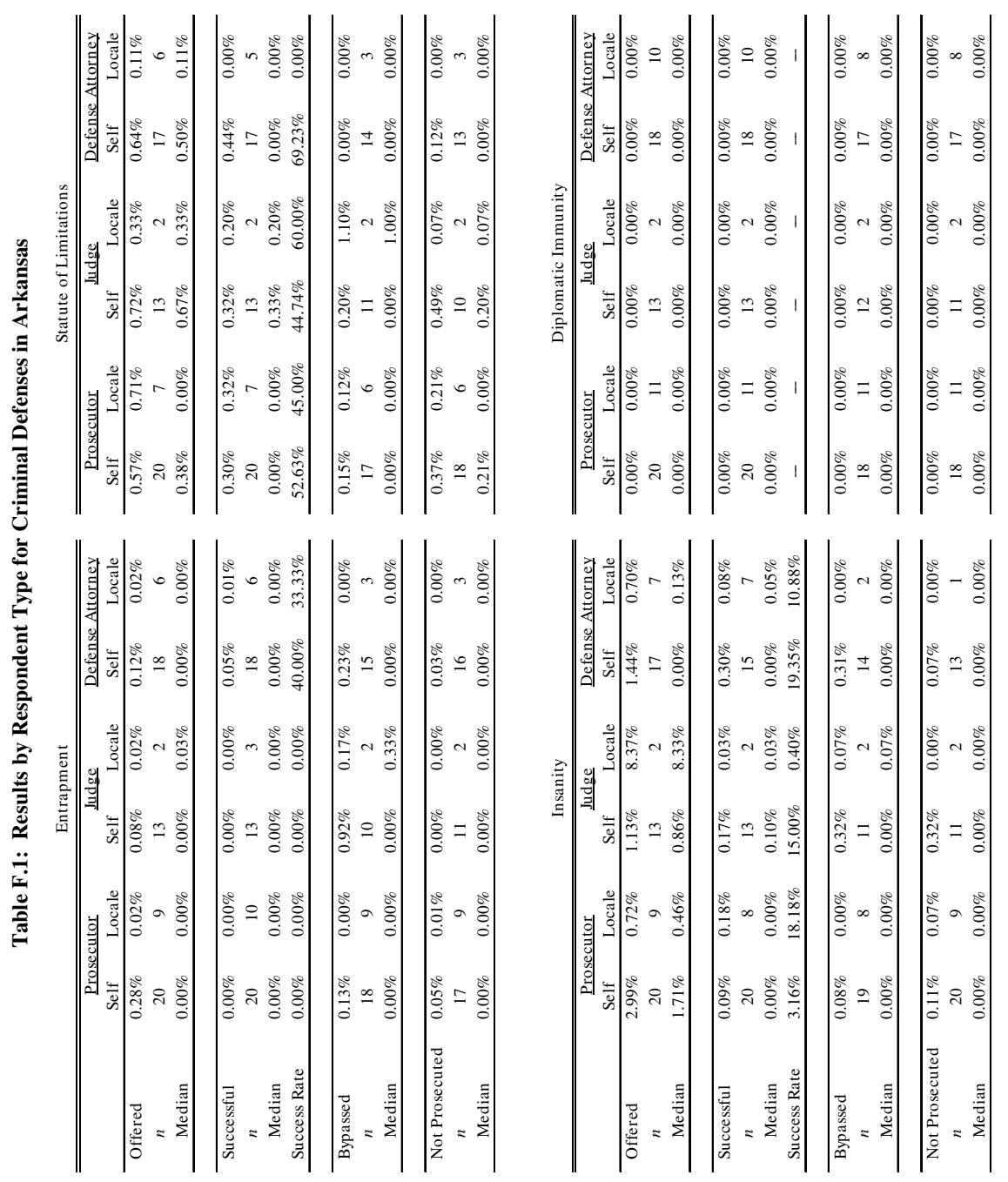




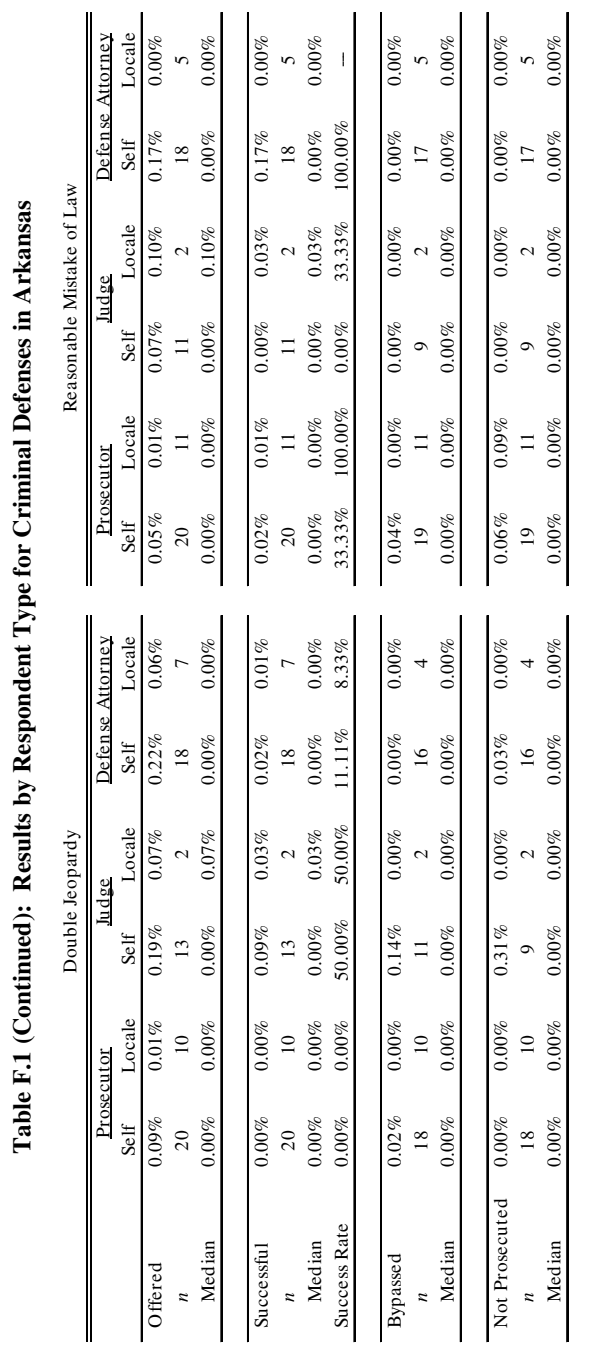



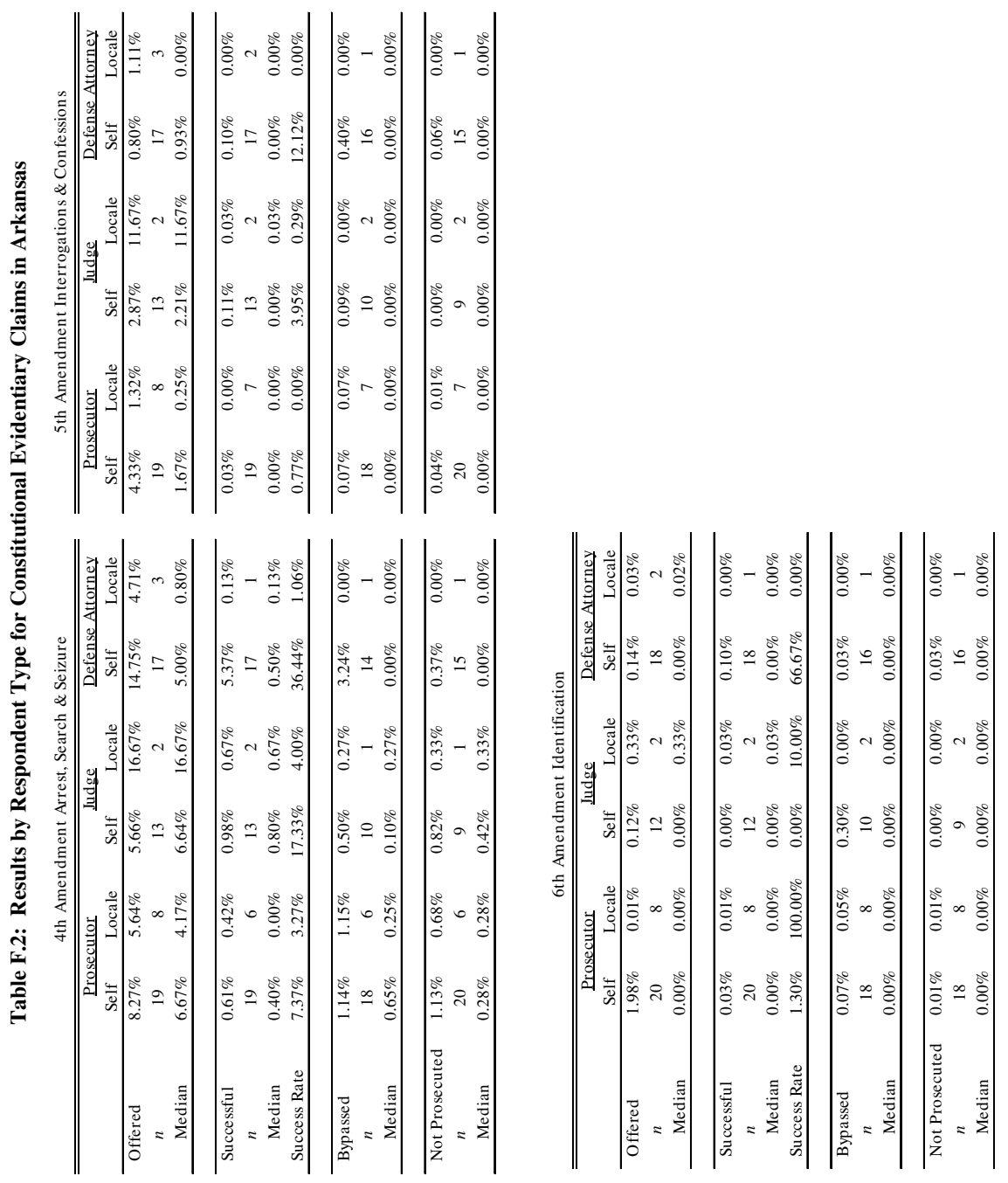


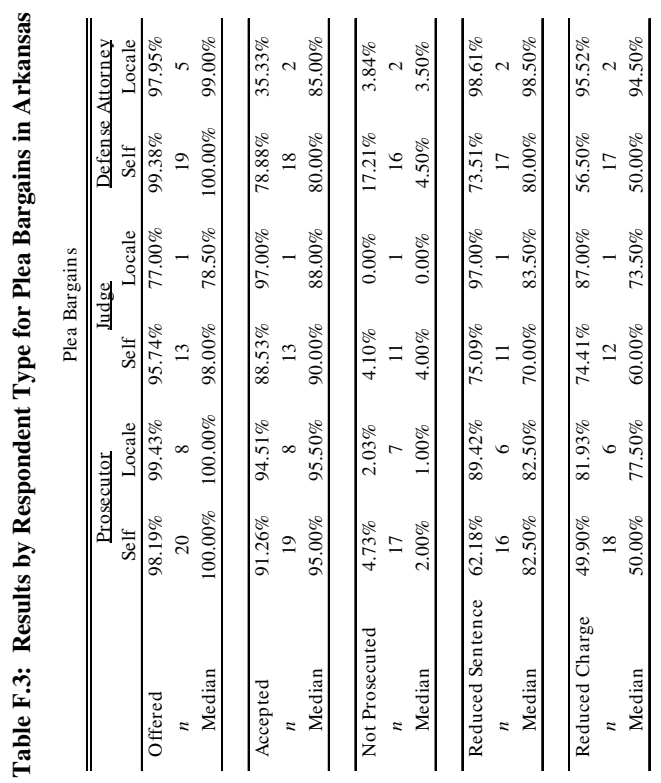




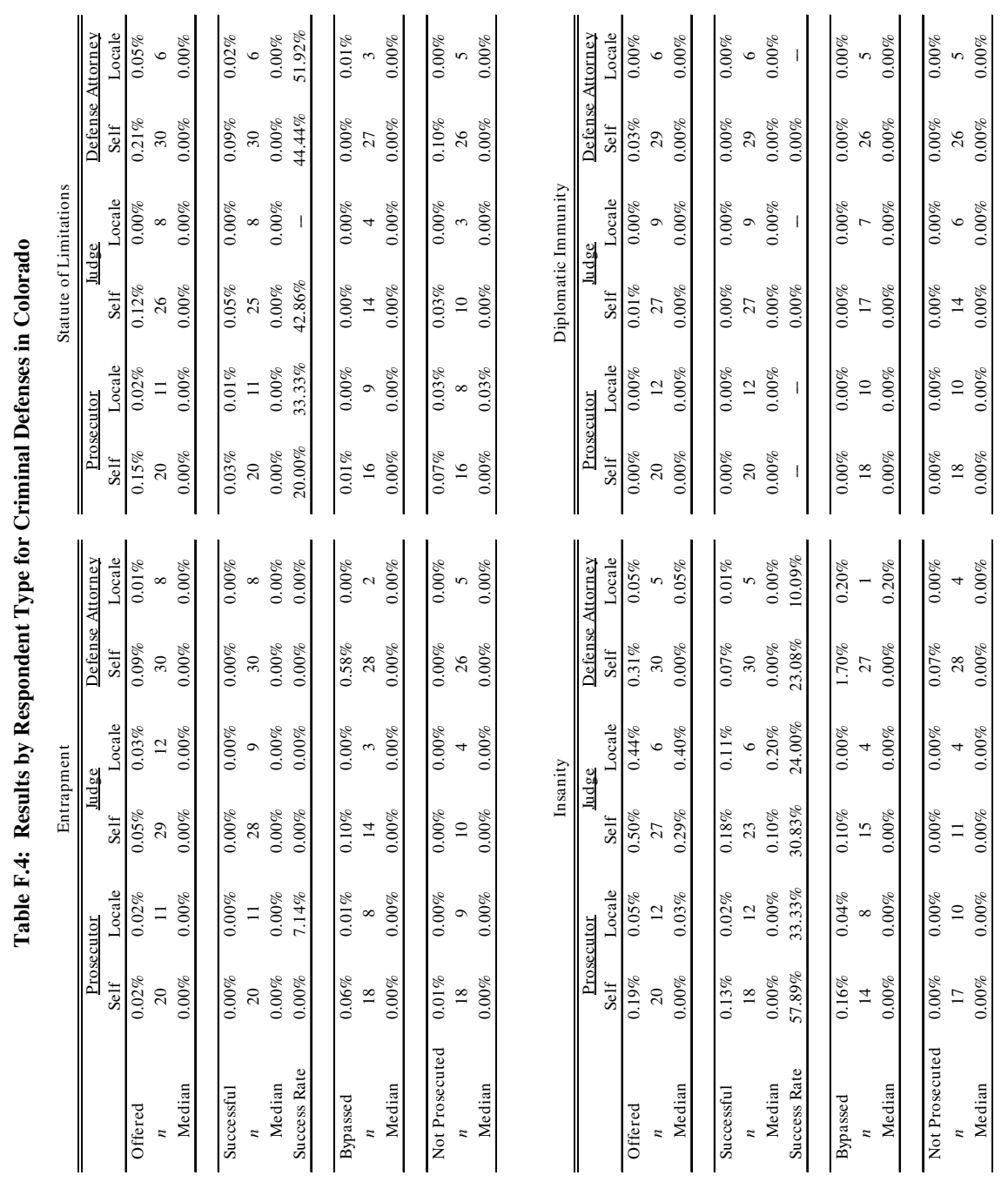


2005]

FREQUENCY AND SUCCESS

1779

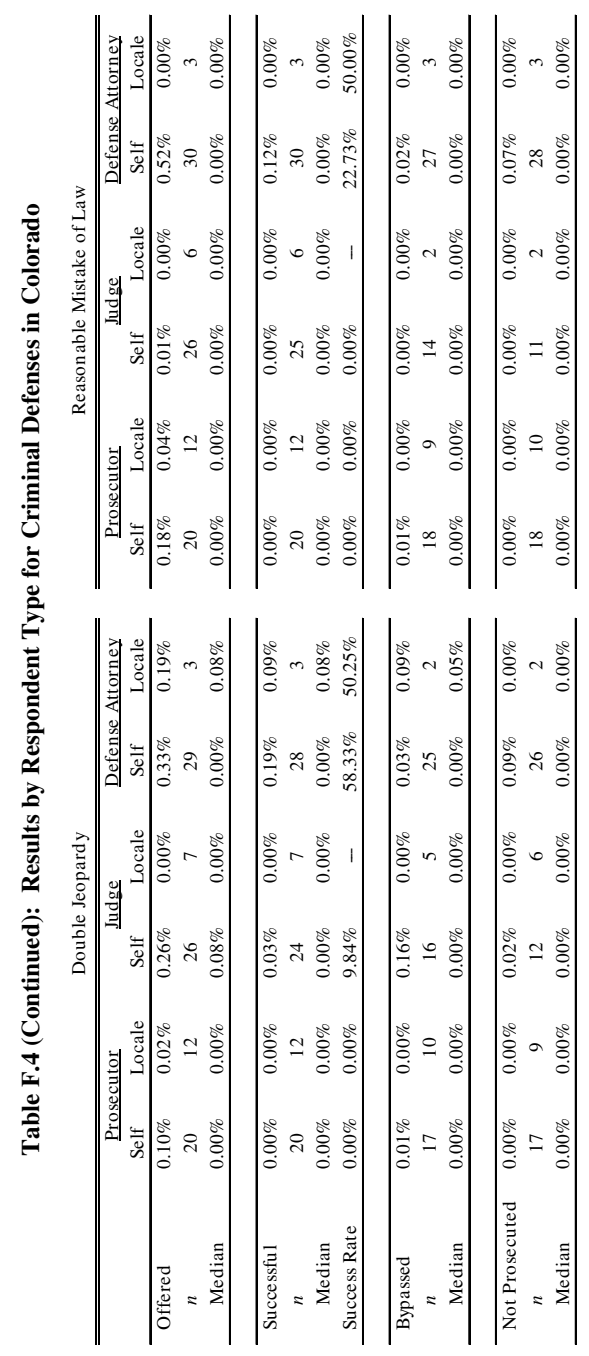




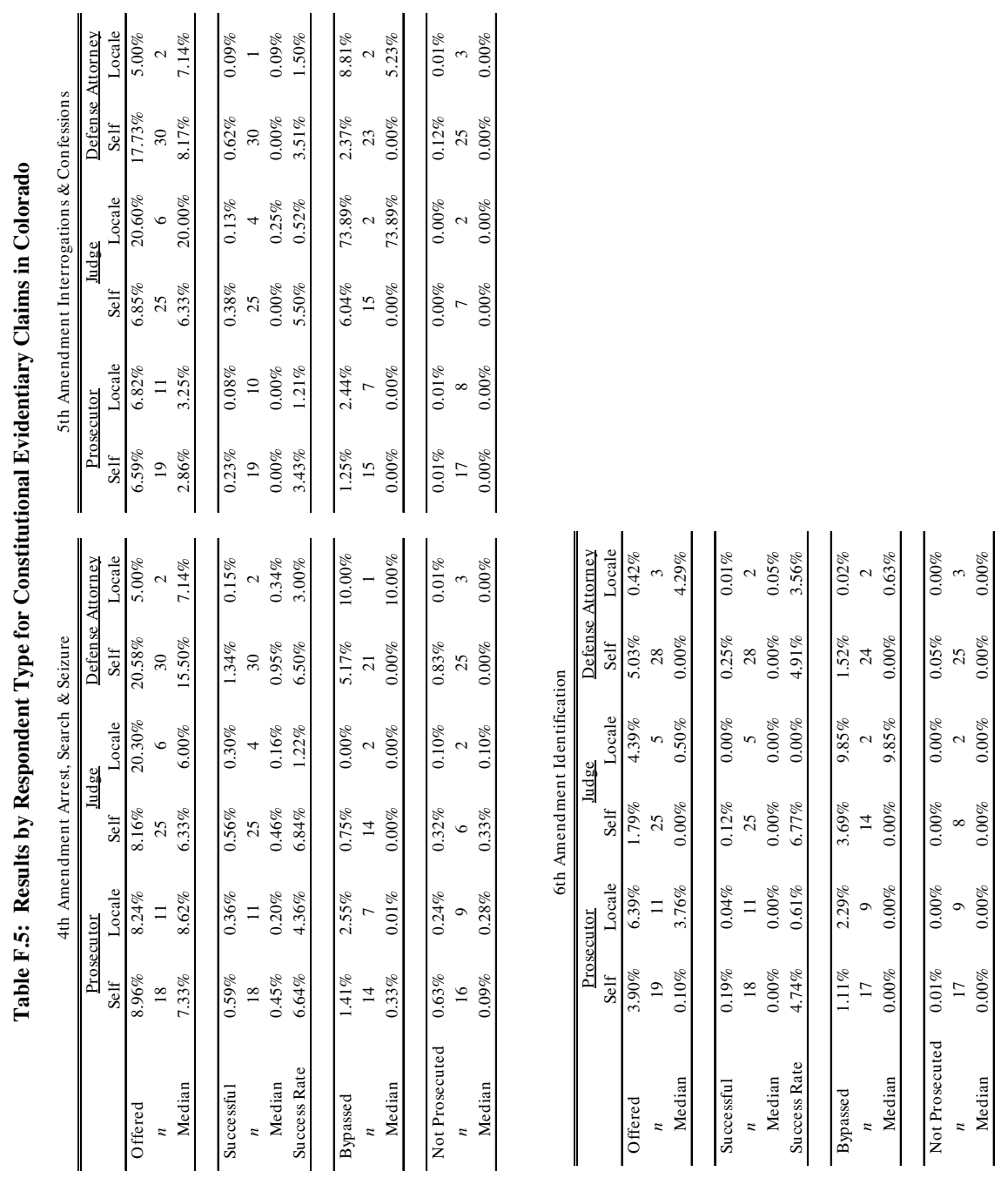




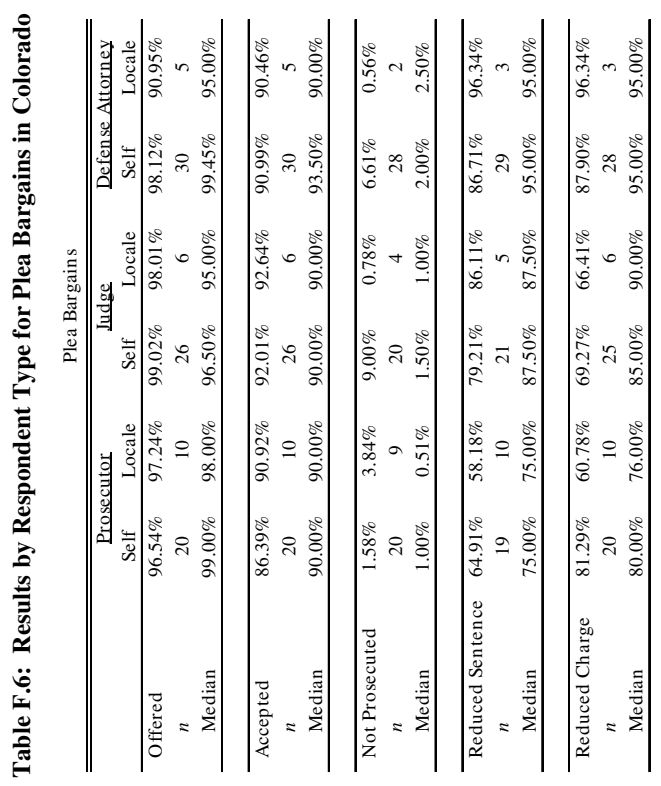




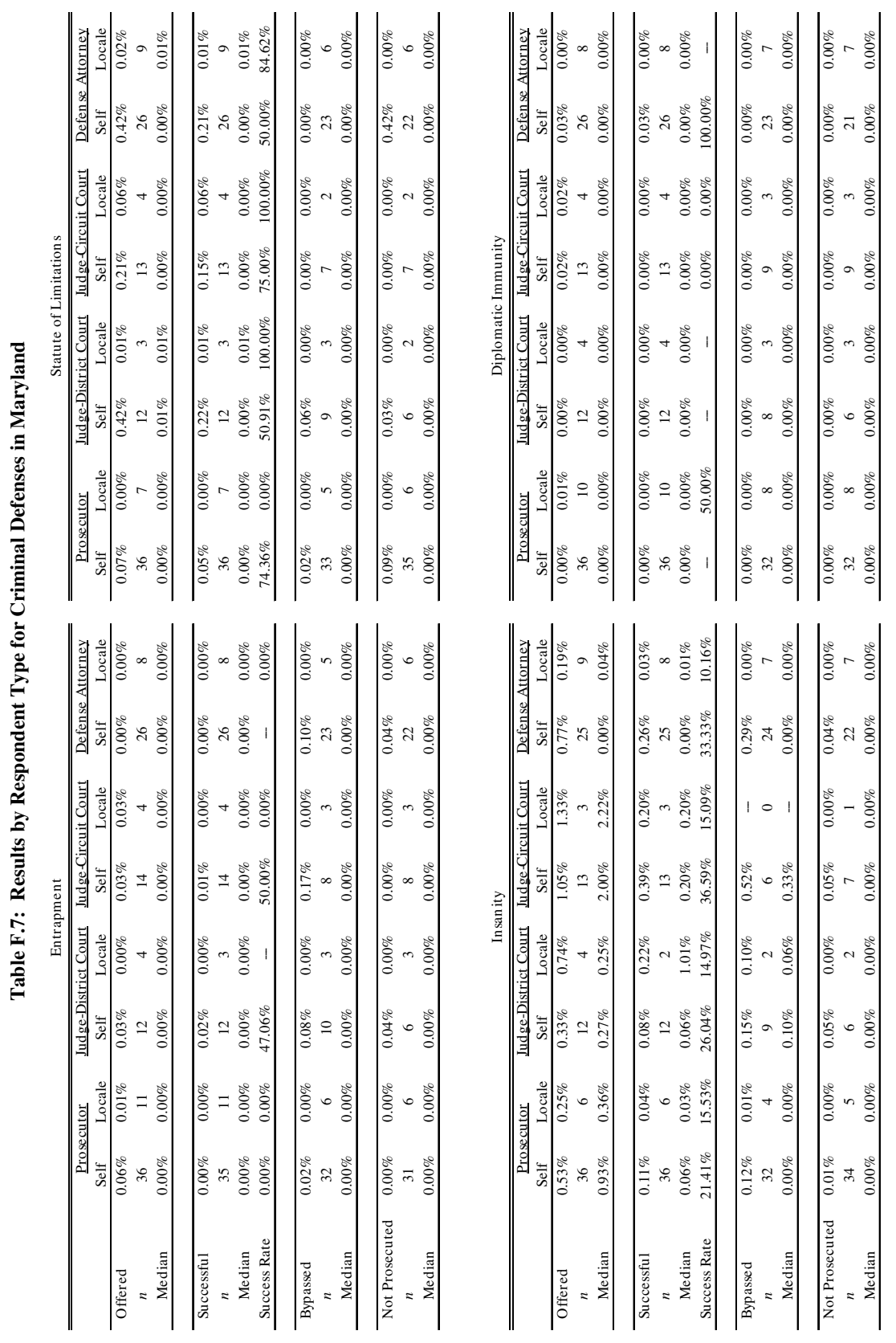




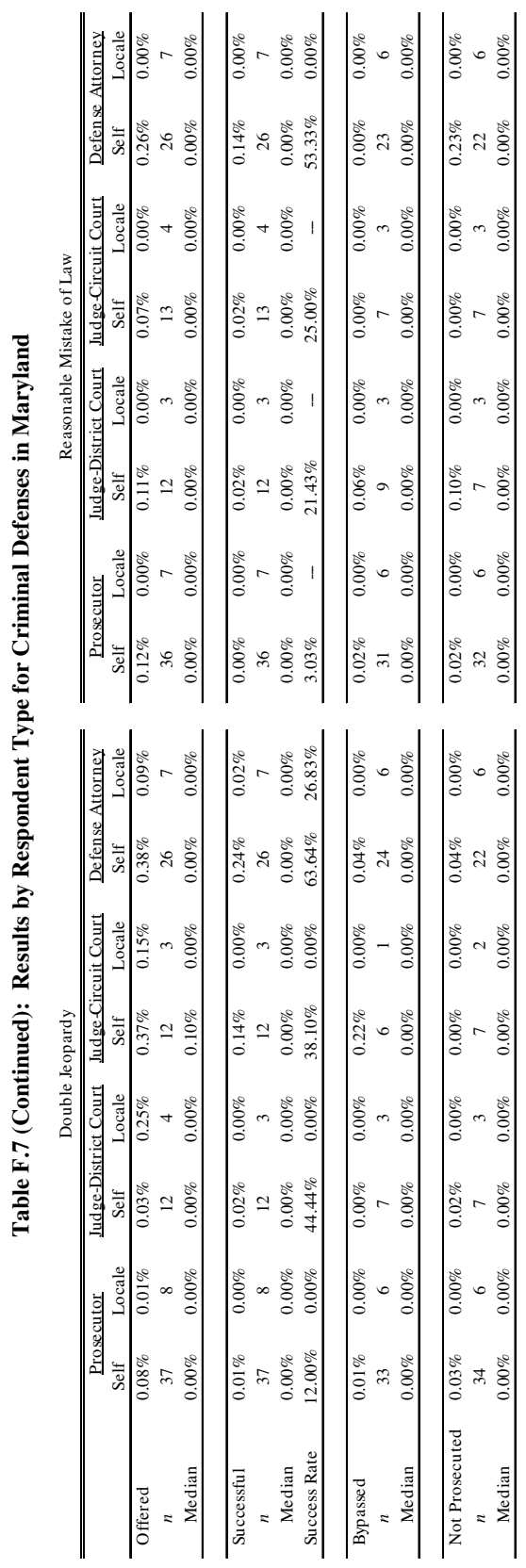




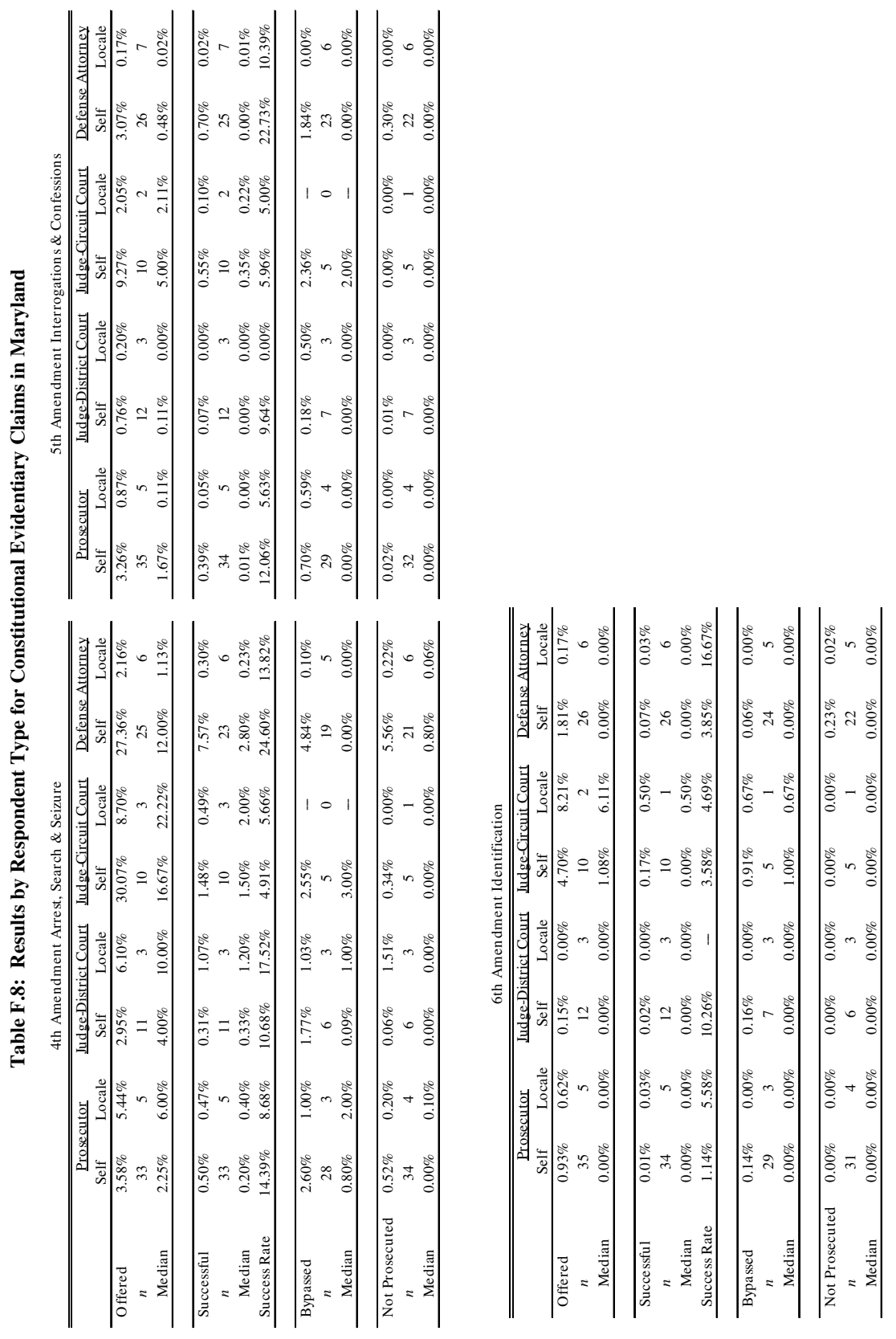




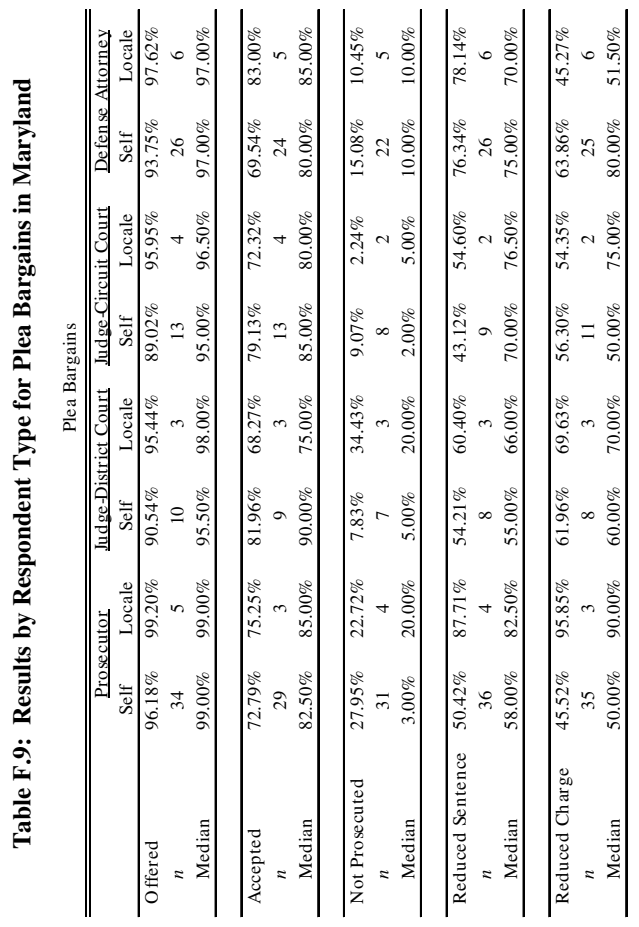




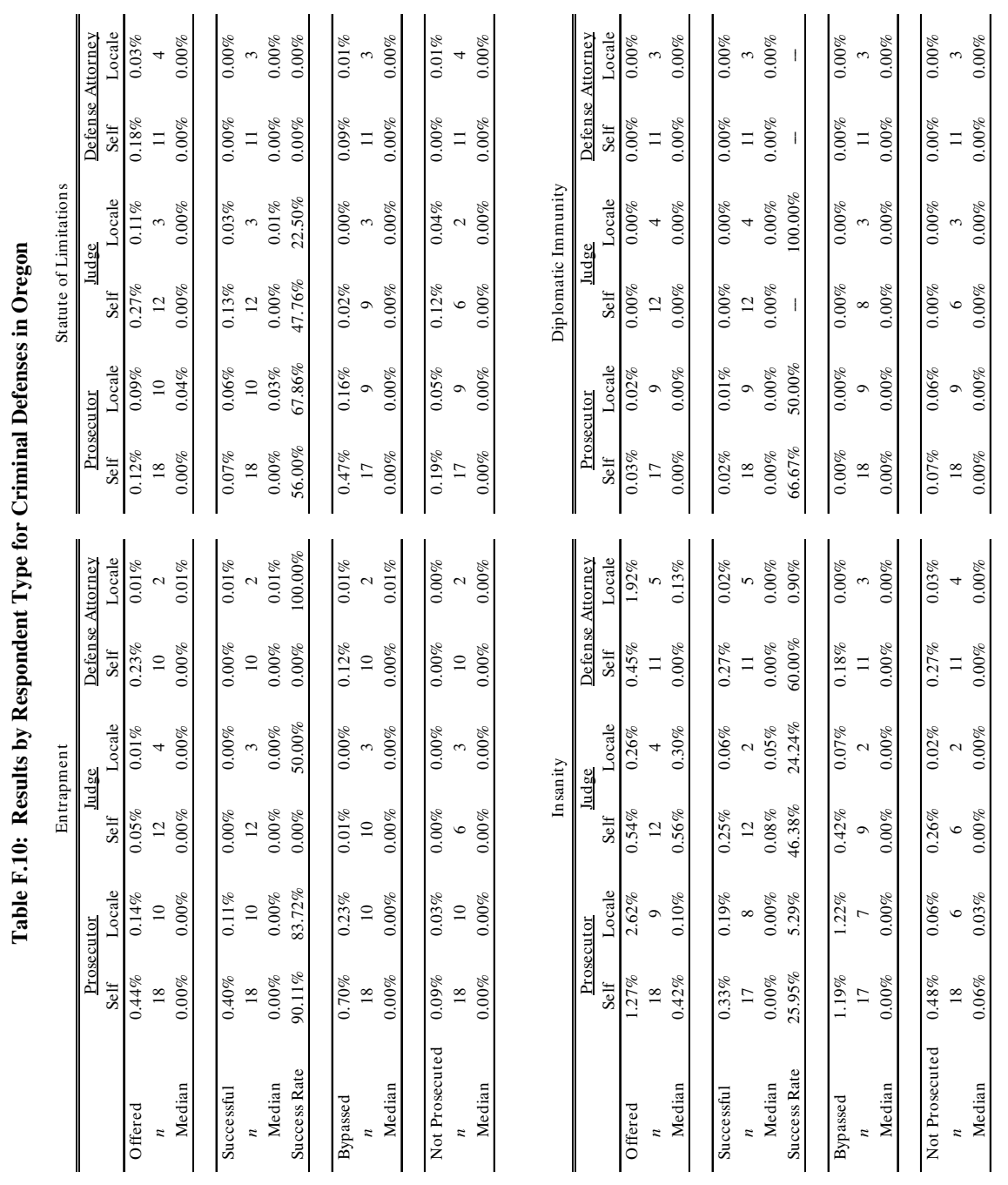


2005]

FREQUENCY AND SUCCESS

1787

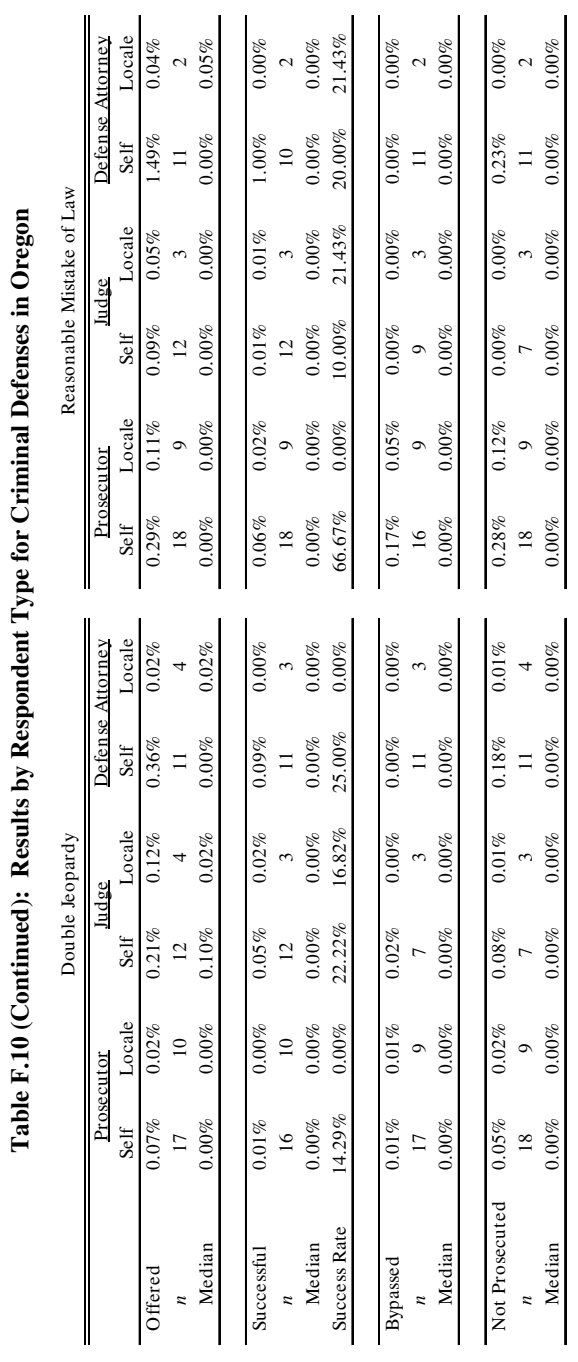




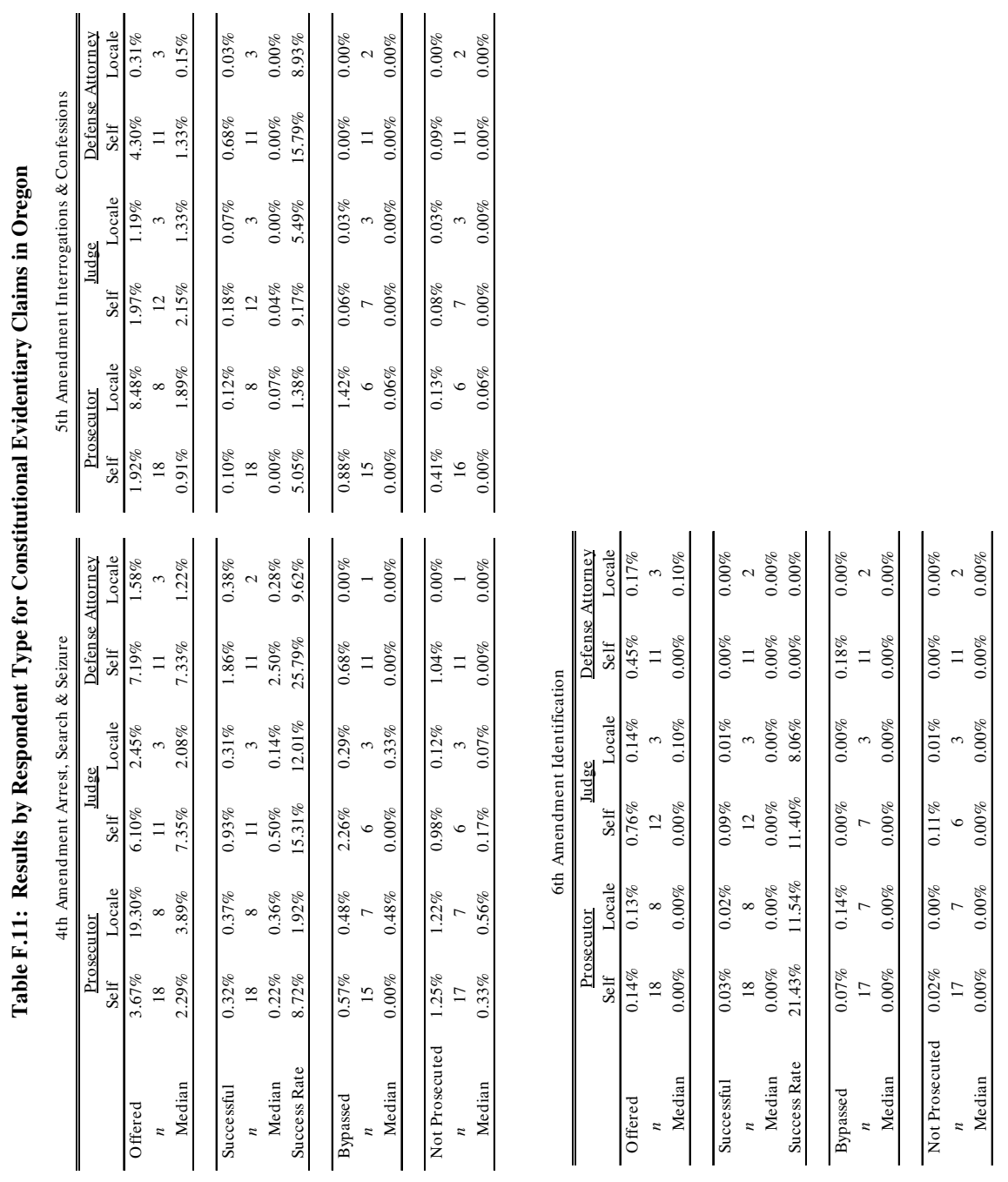




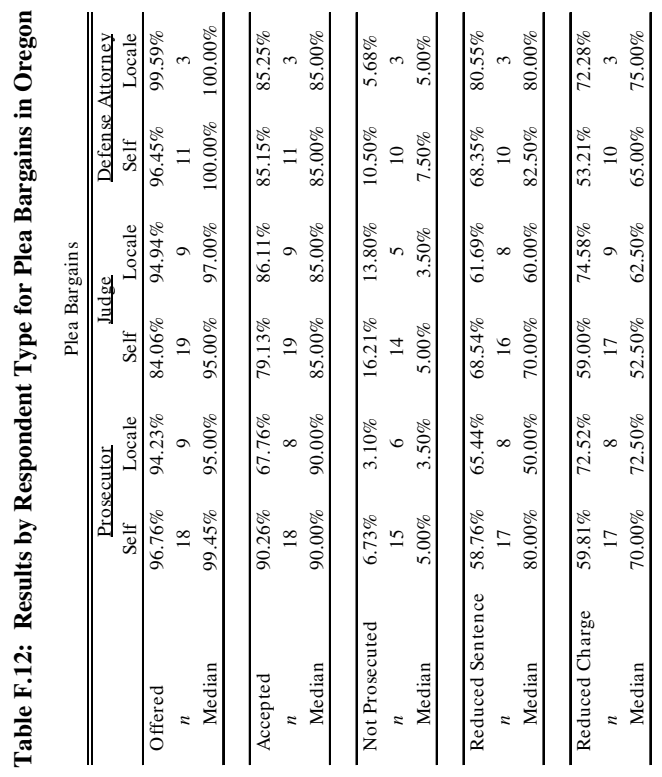



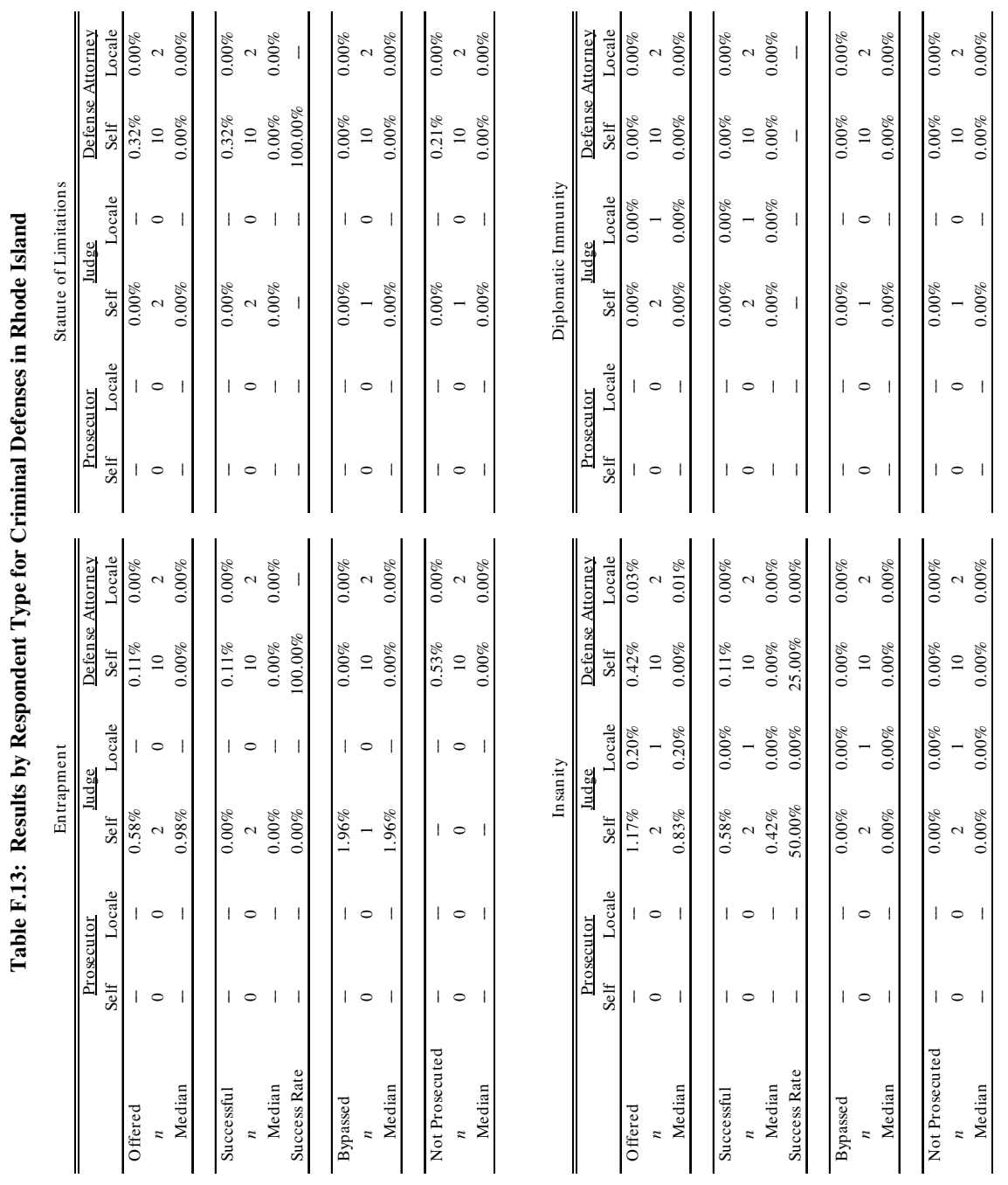


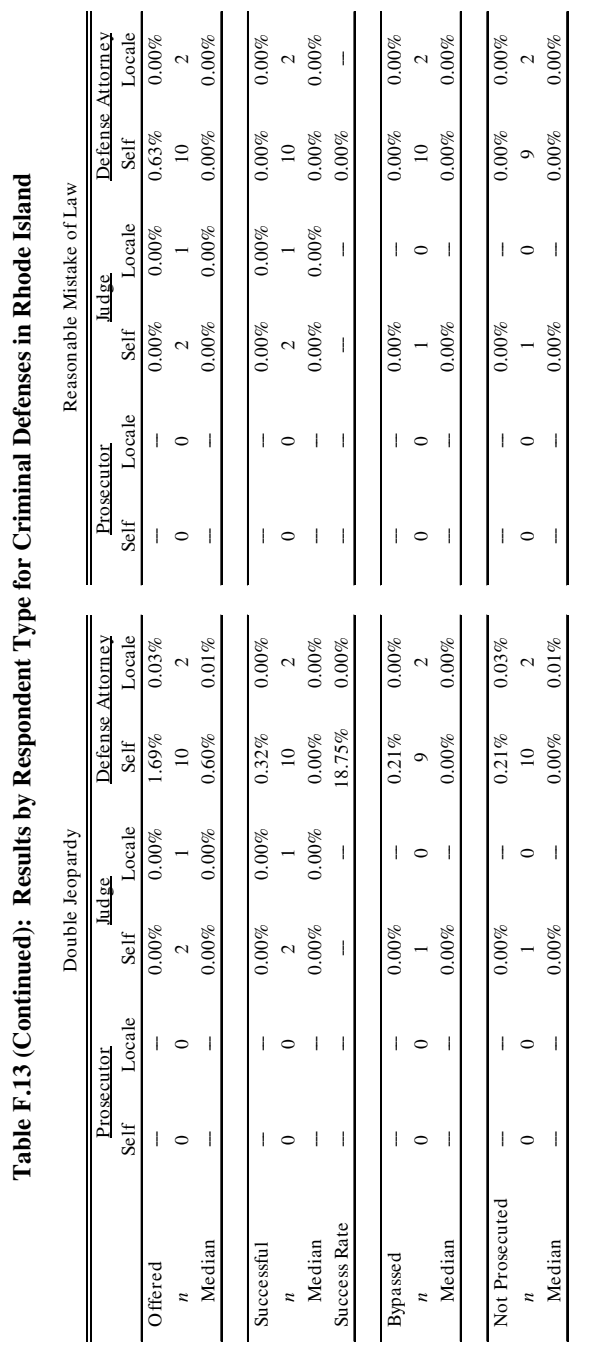




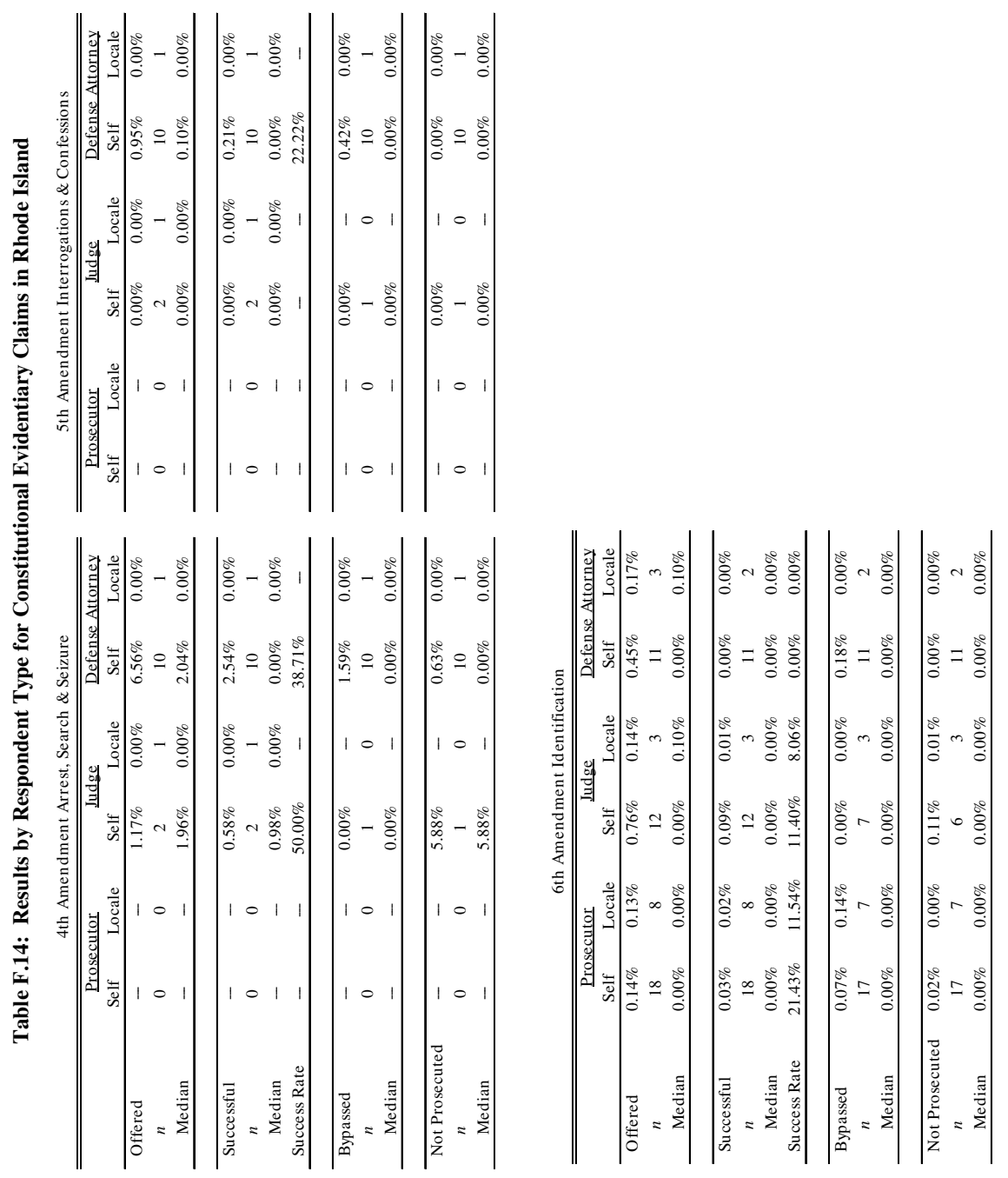




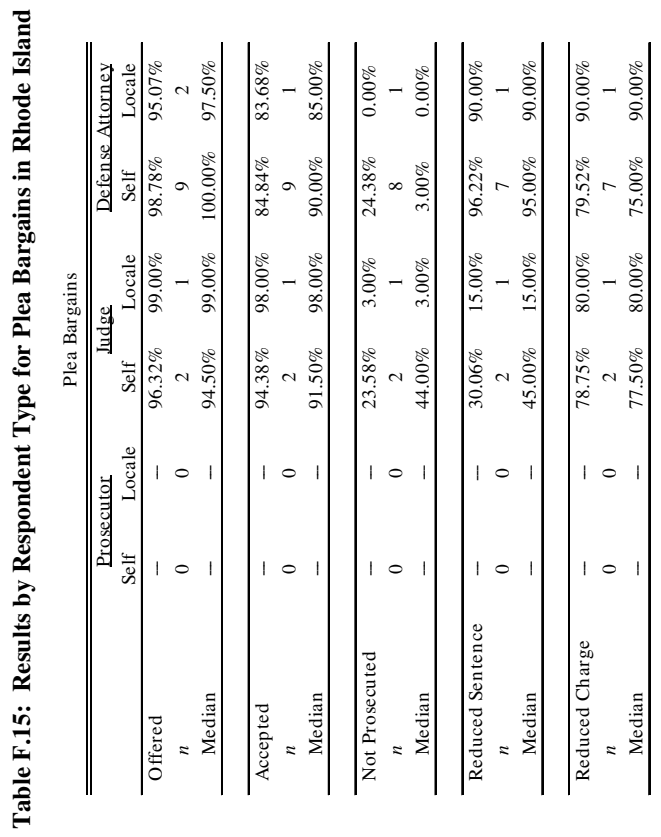




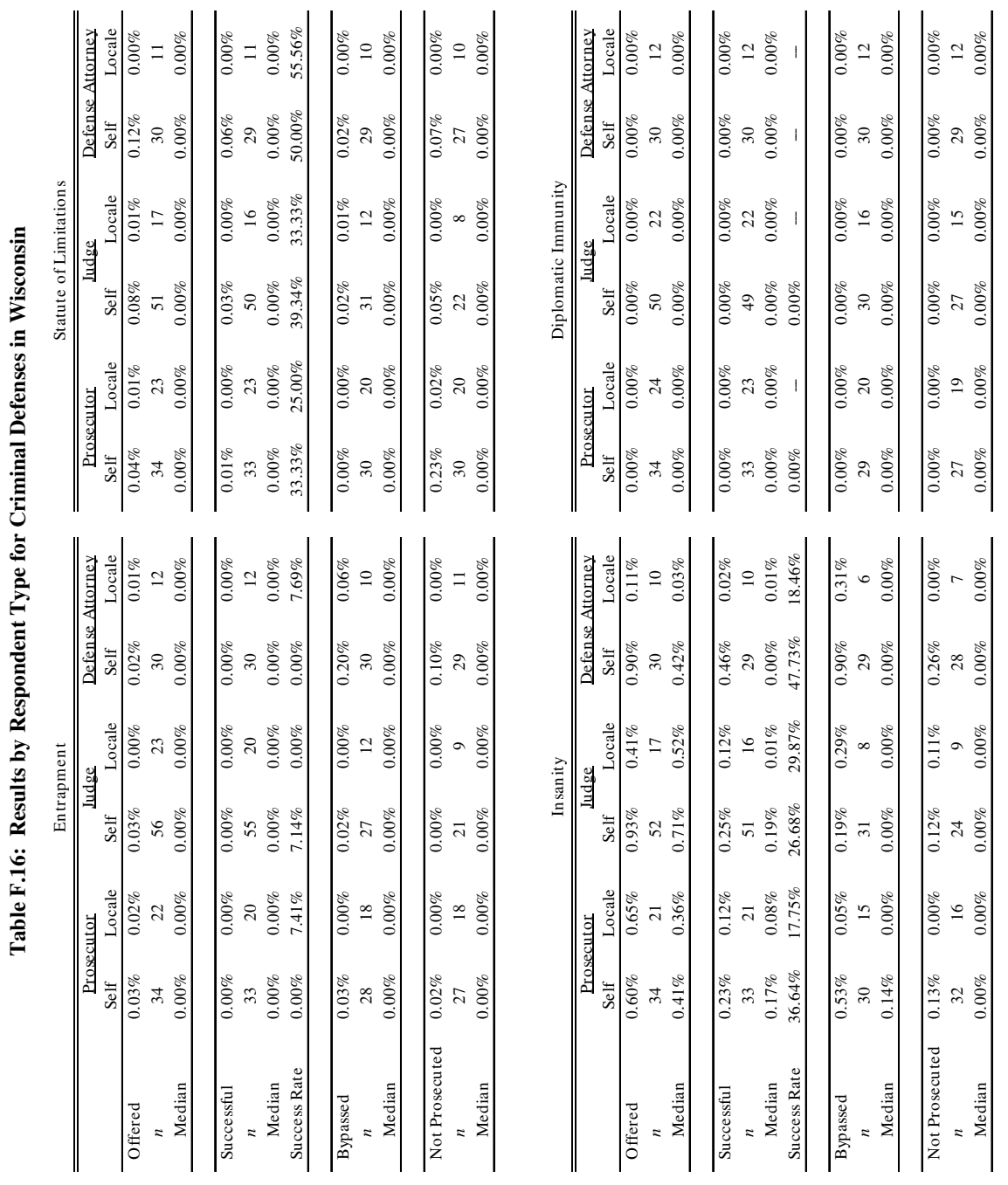




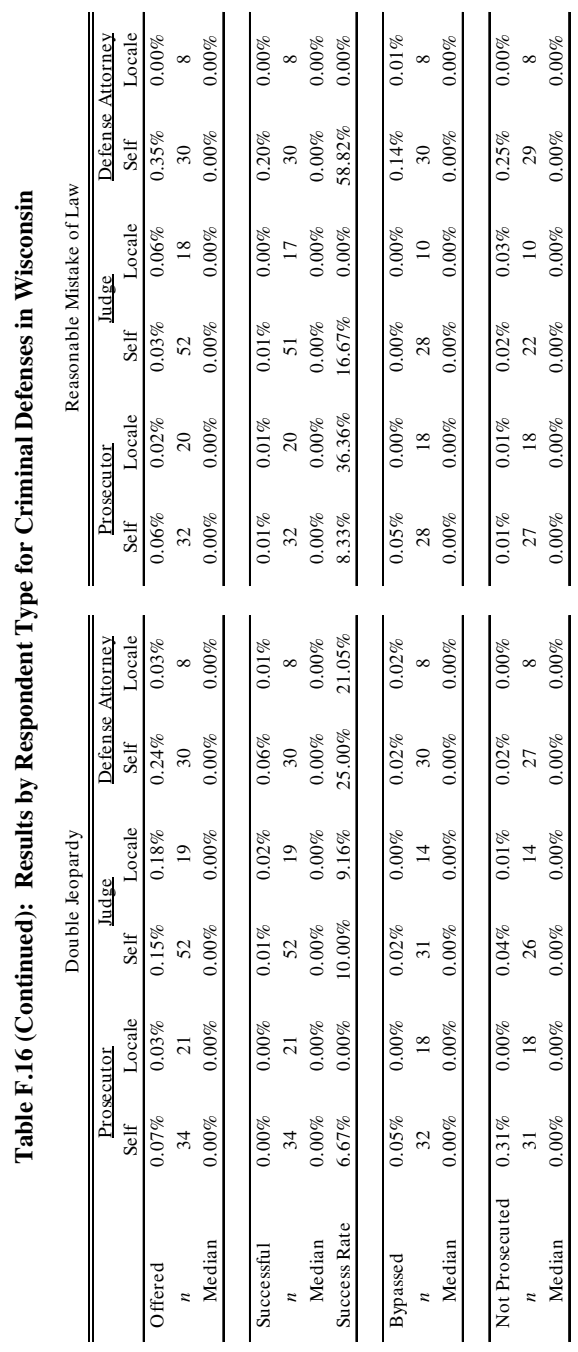



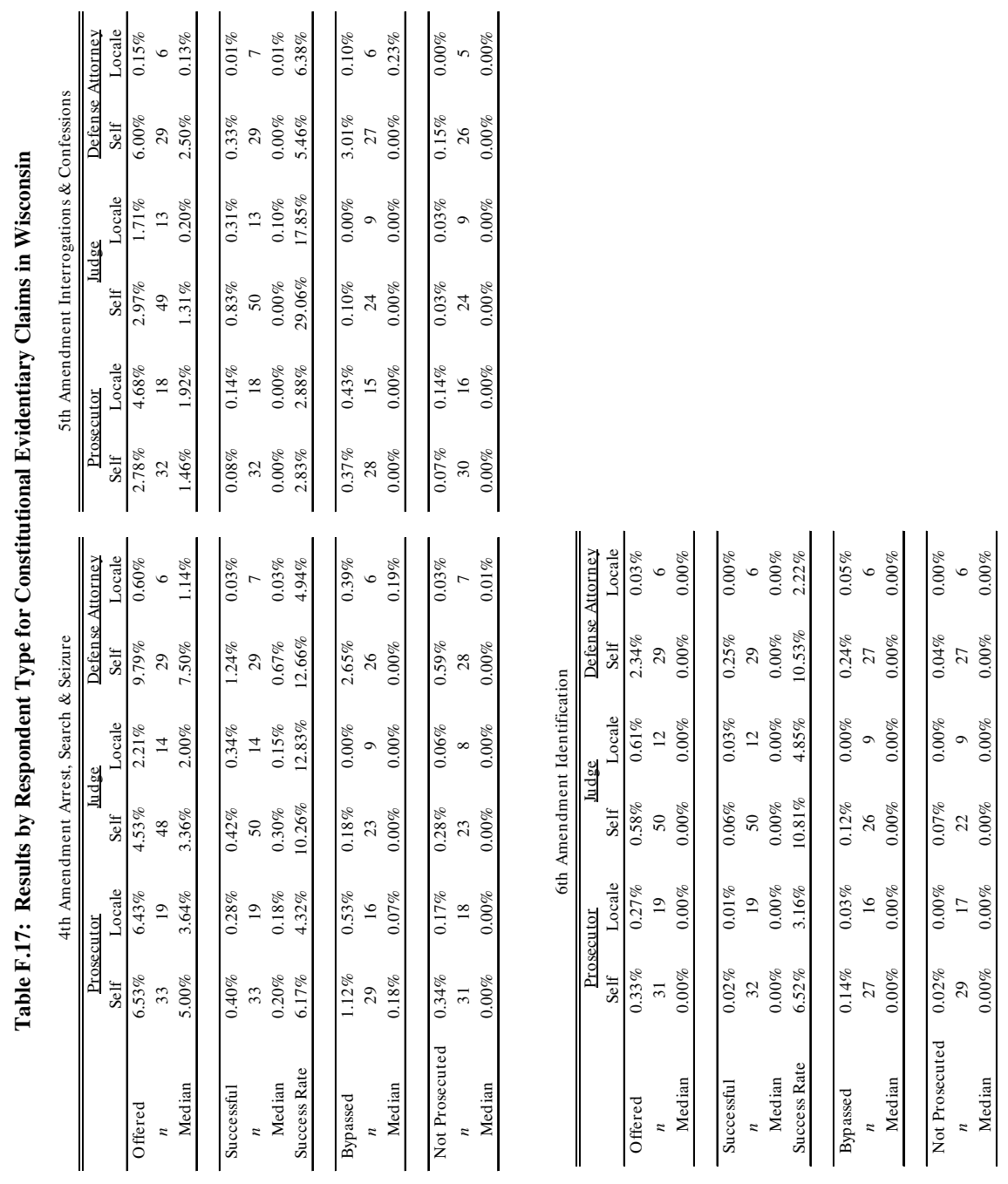


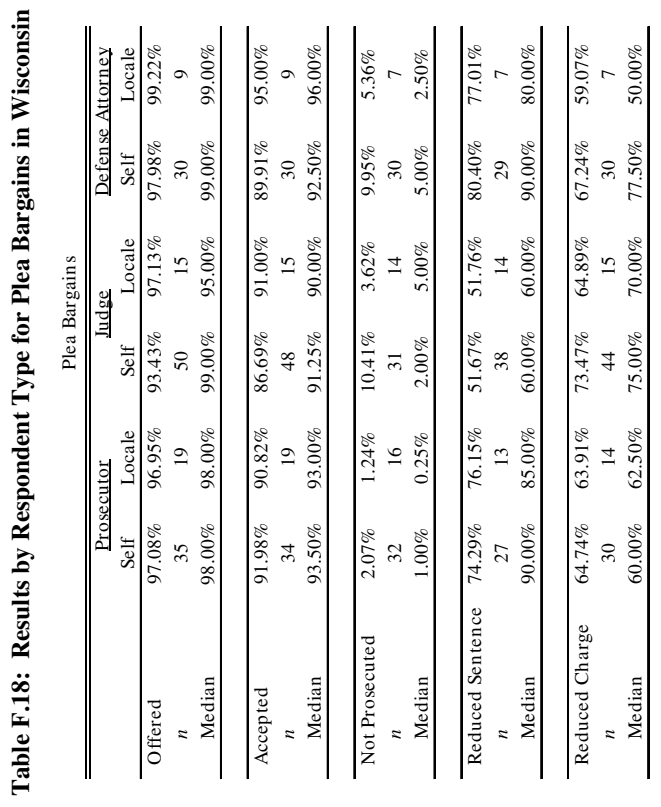




\section{APPENDIX G: SURVEY REsults By AREA AND RESPONDENT Type}

The results in Appendix G represent the aggregation of responses from each individual area type (i.e., Urban, Suburban, Rural, or Mixed) within each category of repondent (i.e., prosecutor, judge, or defense attorney). The area-type divisions in these categories are based on the self-reporting of respondents. The tables titled "Urban," "Suburban," and "Rural" contain all respondents who selected one of those categories as describing the area from which most of their cases originate. The tables titled "Mix" contain all respondents who selected more than one of these categories. 


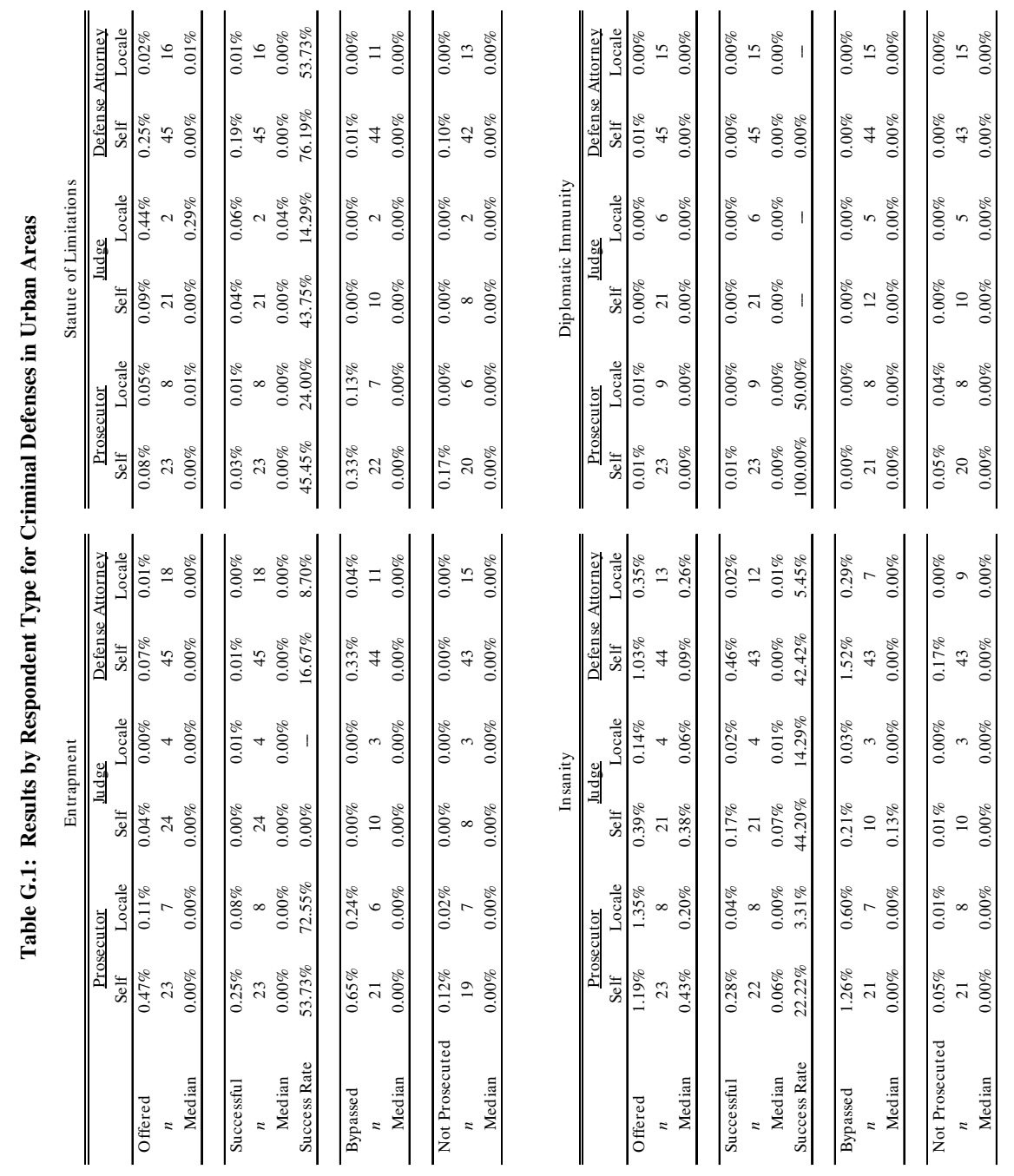




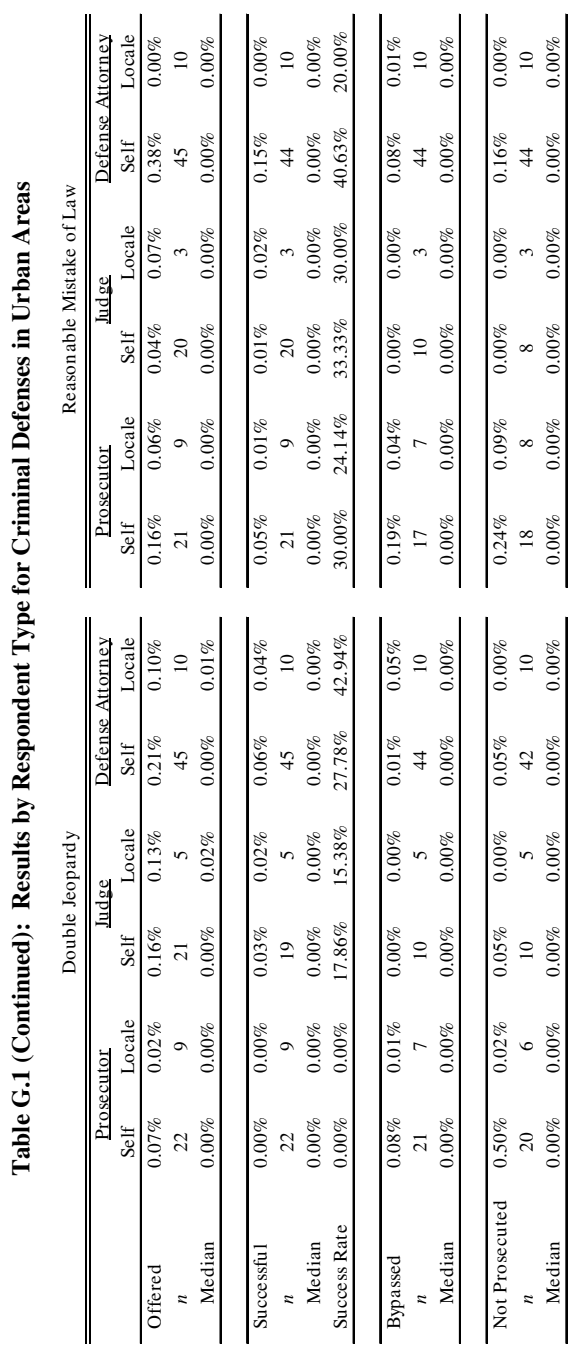




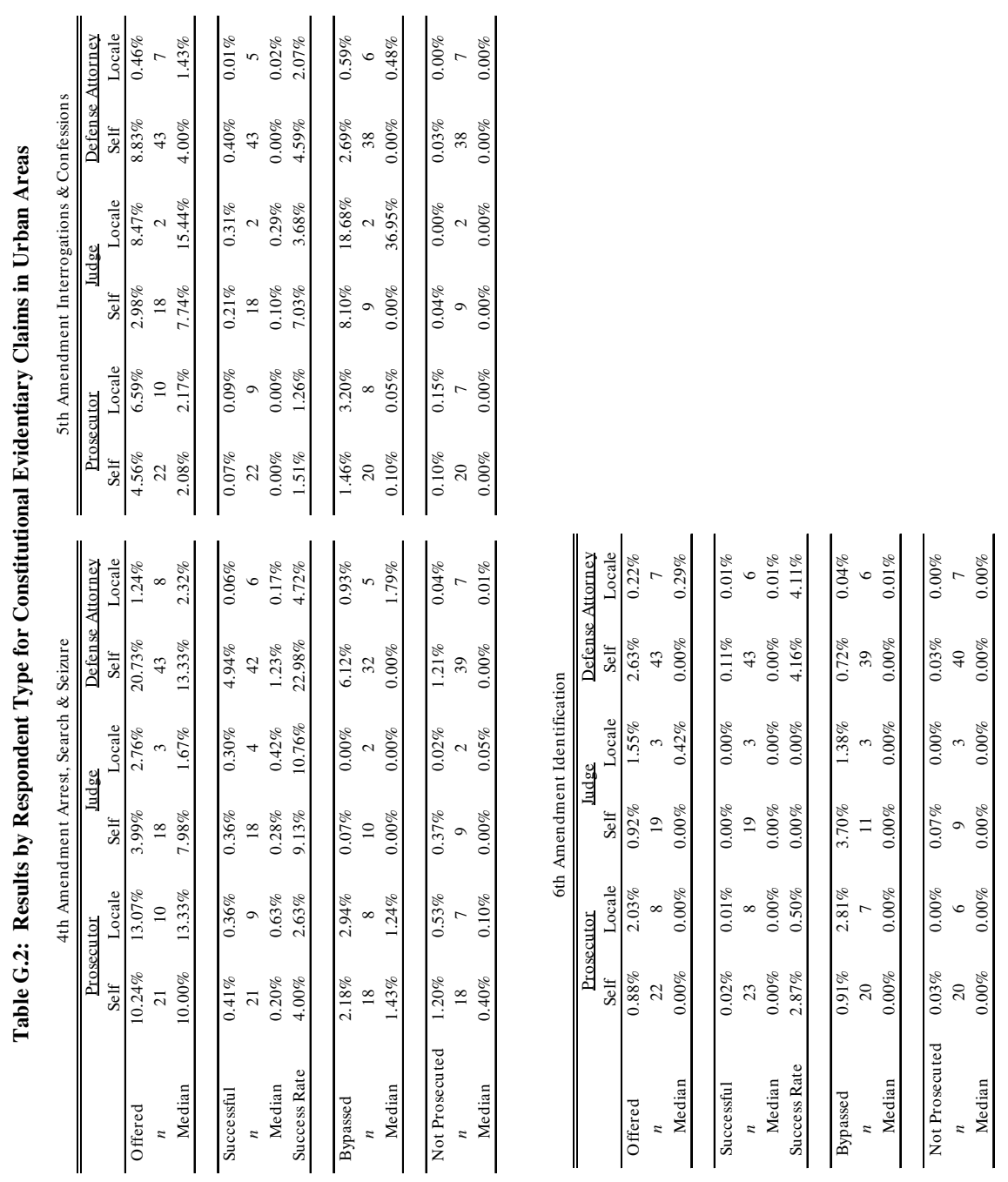




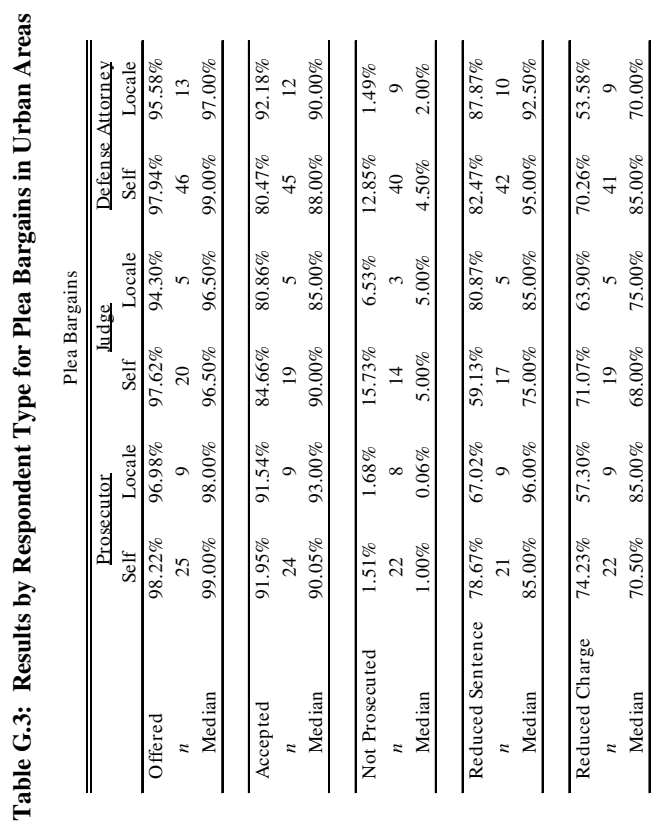




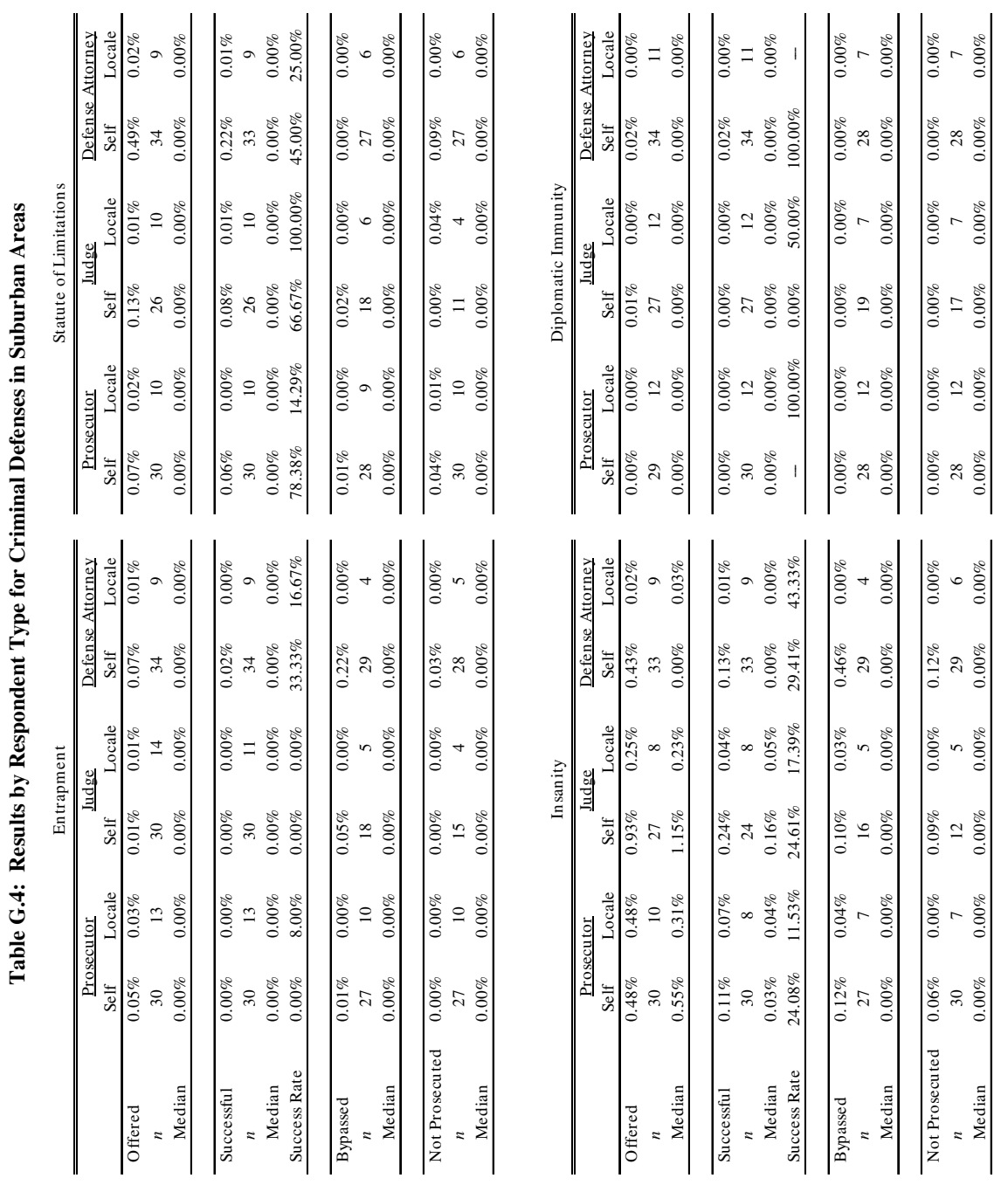




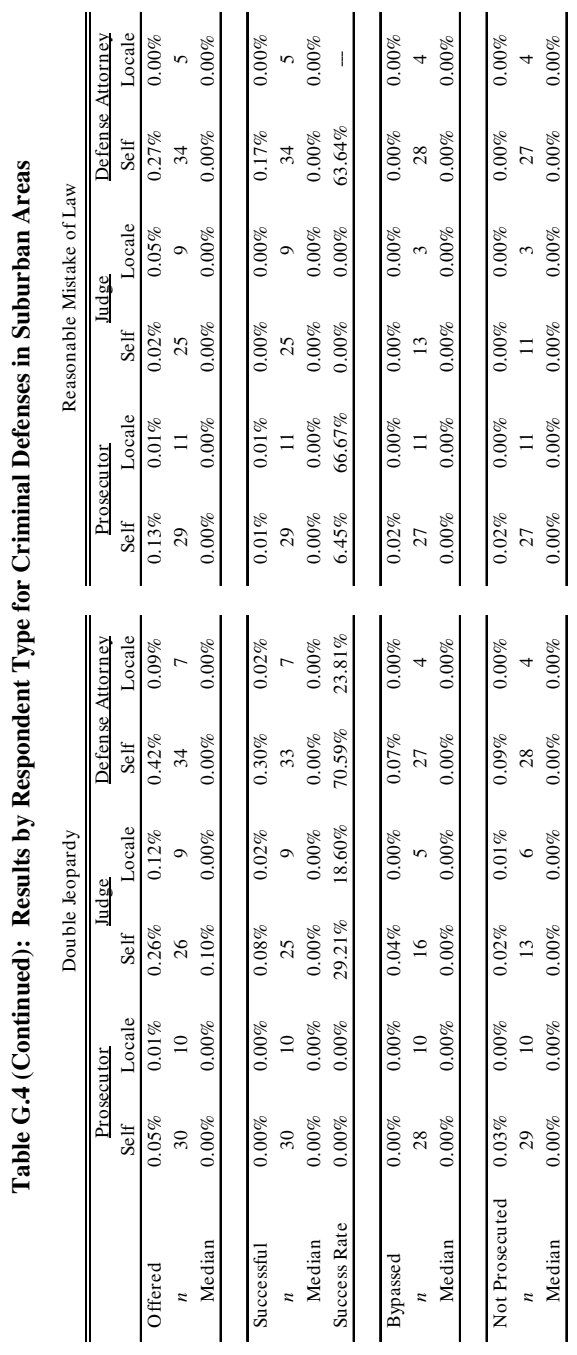




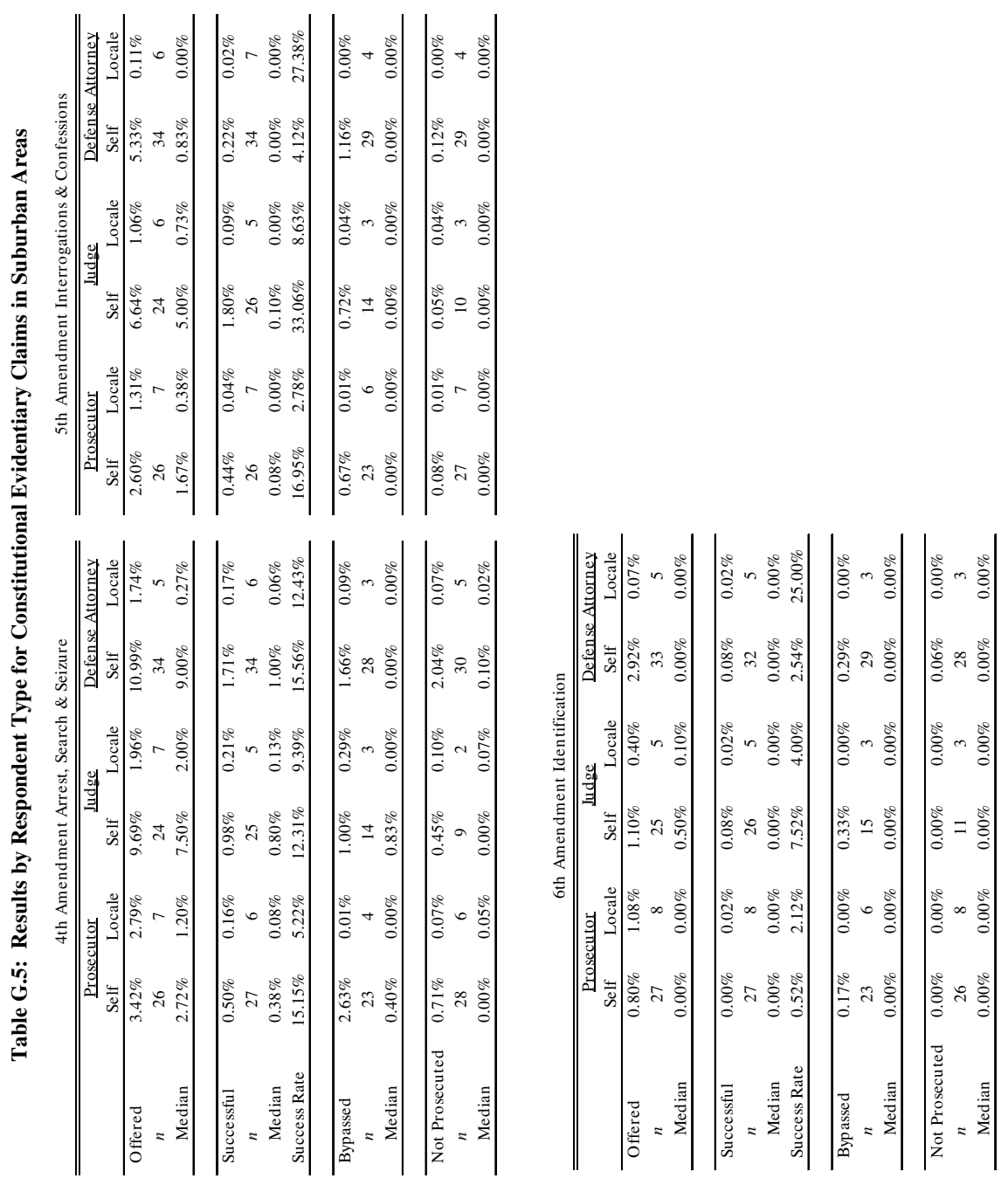




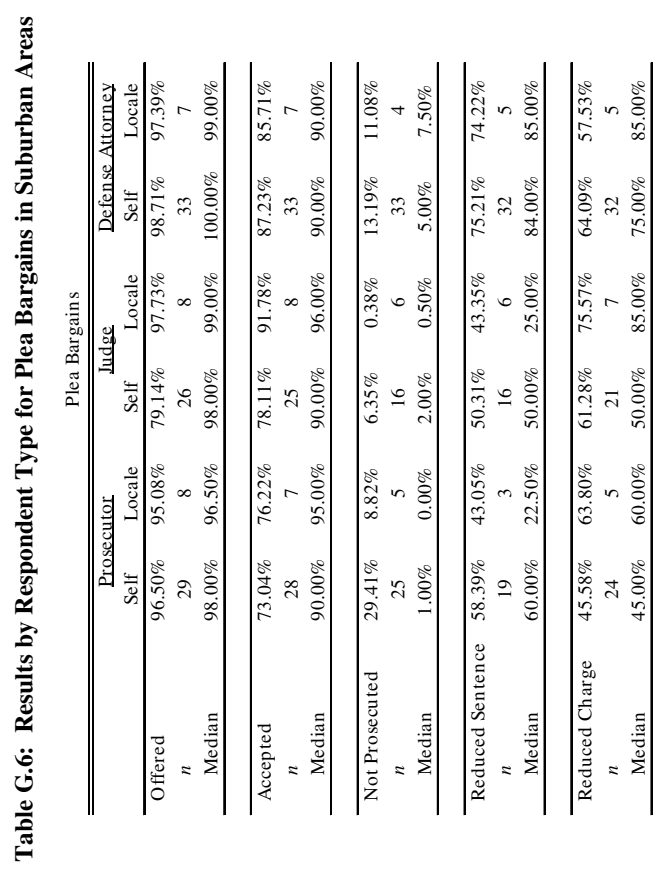




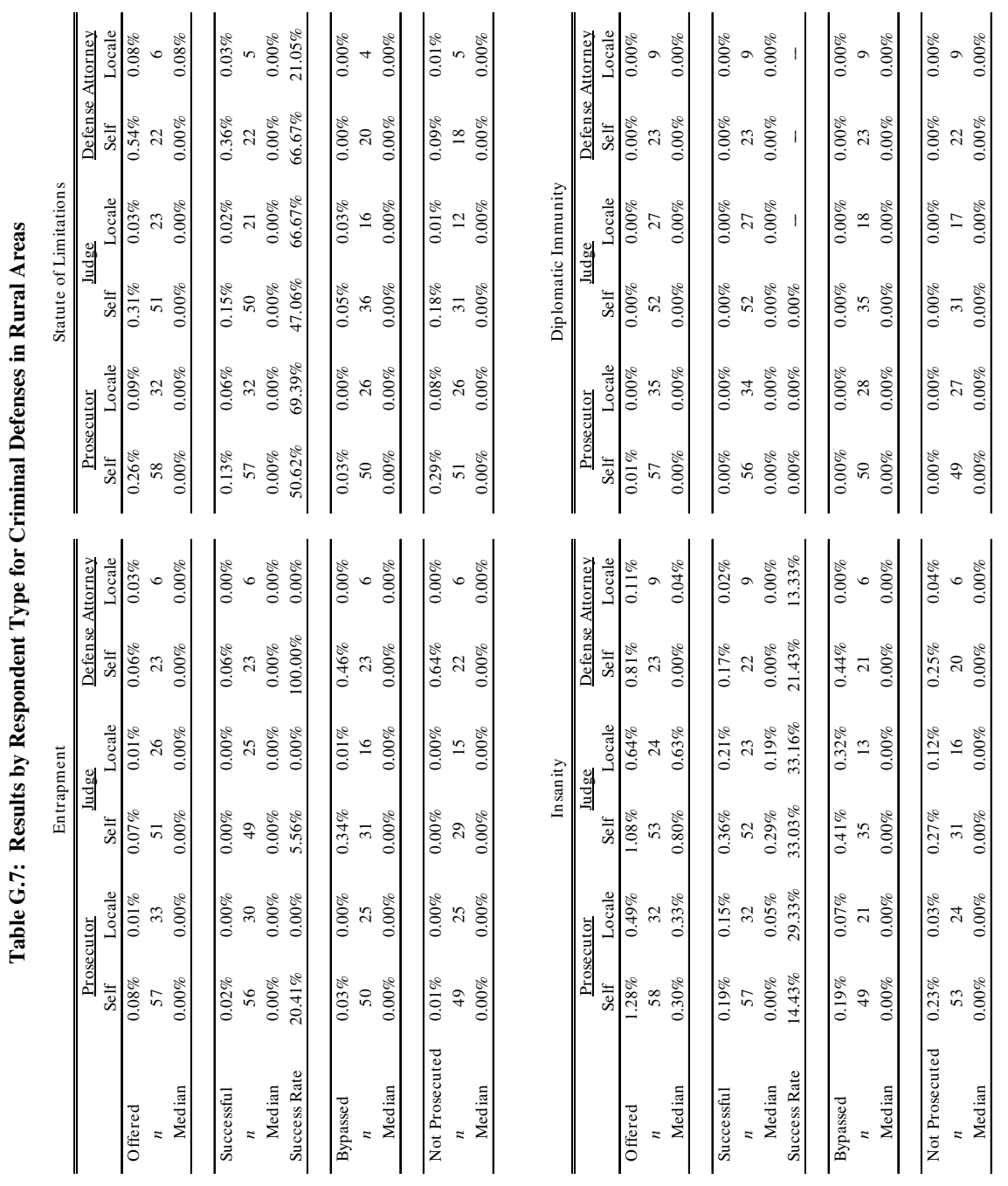




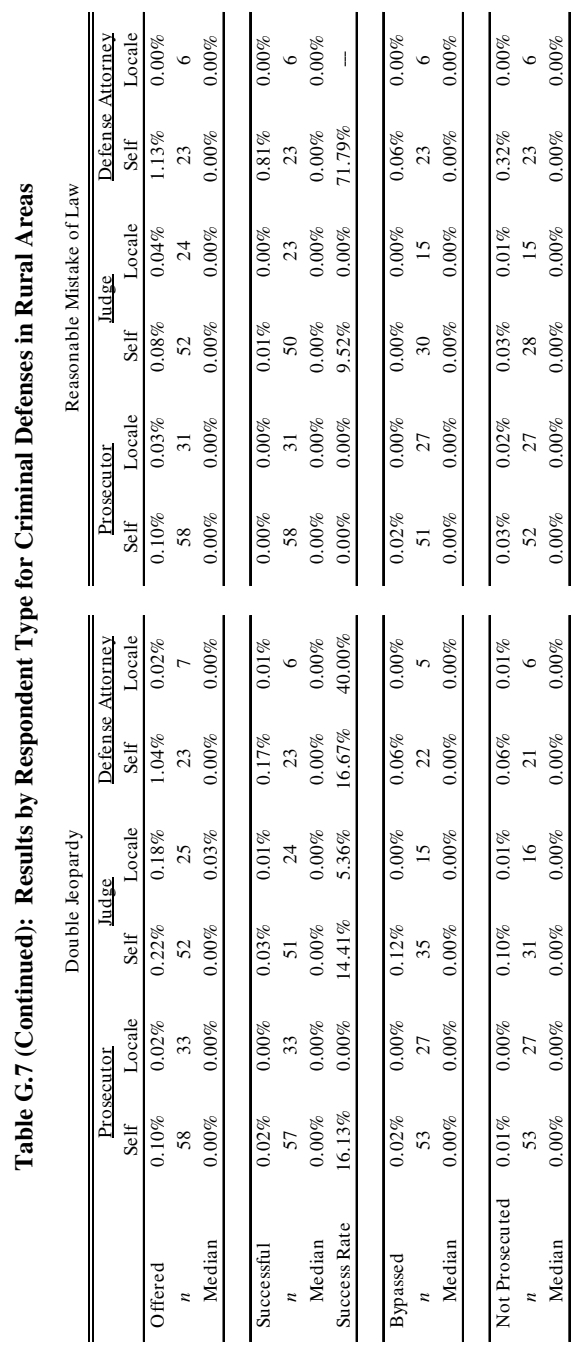




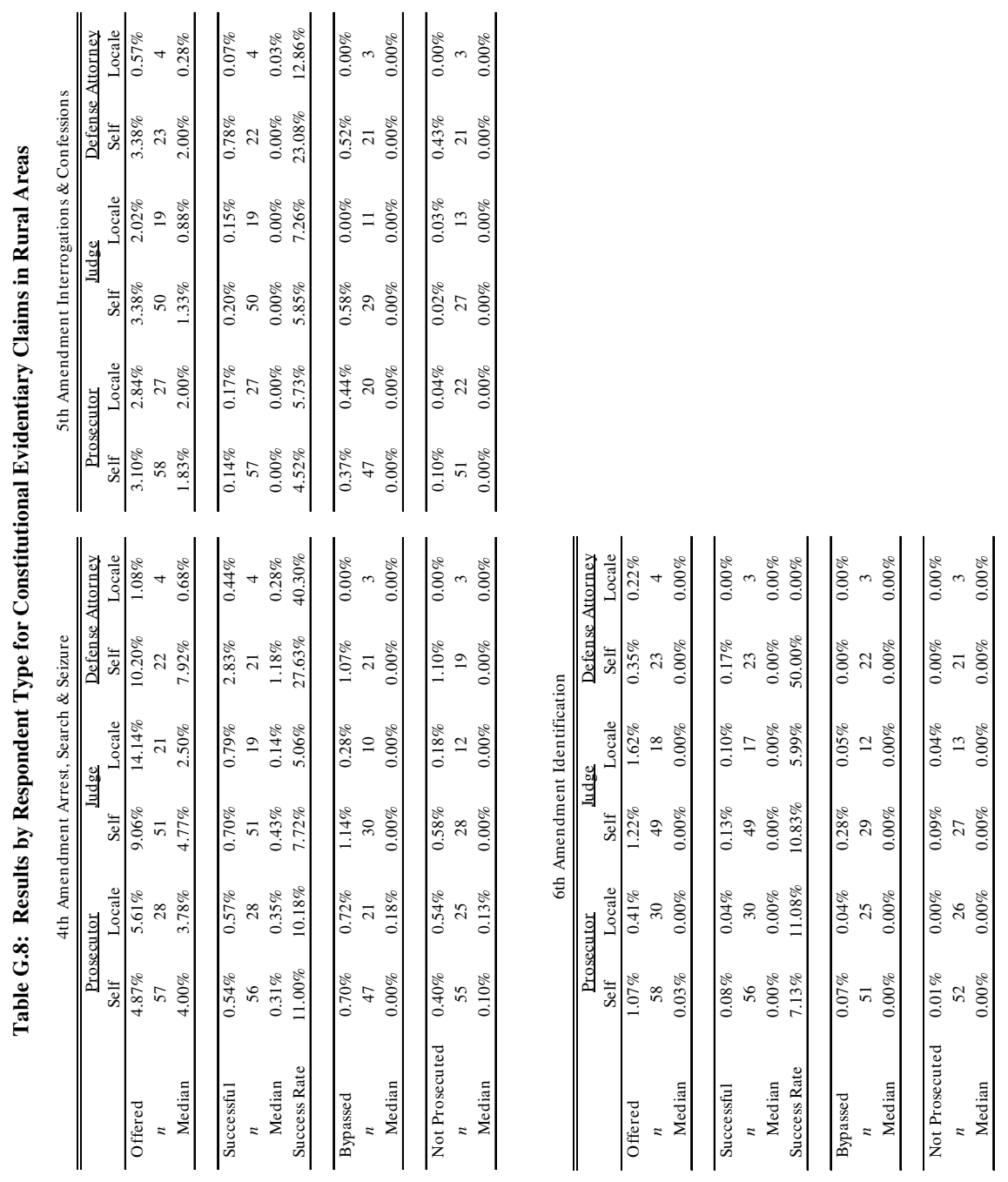




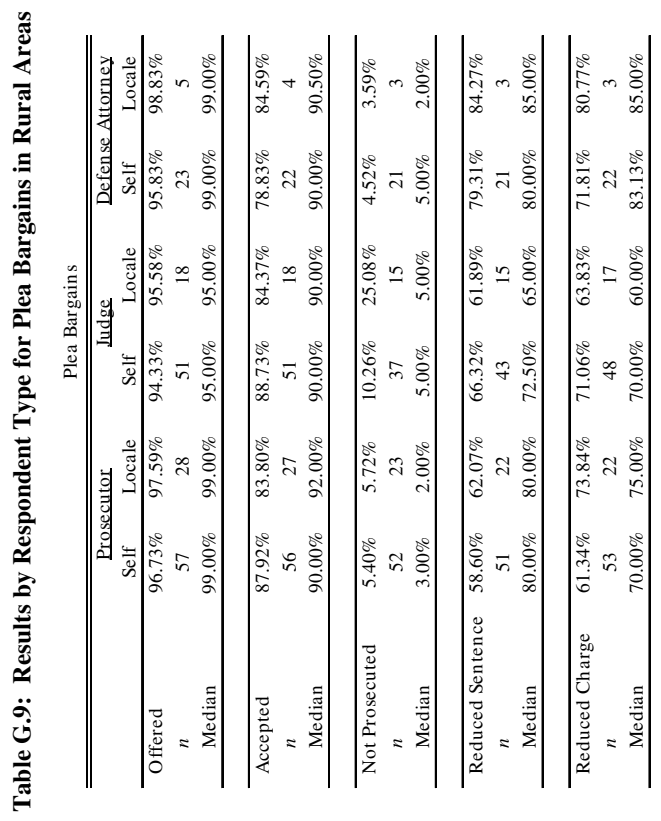




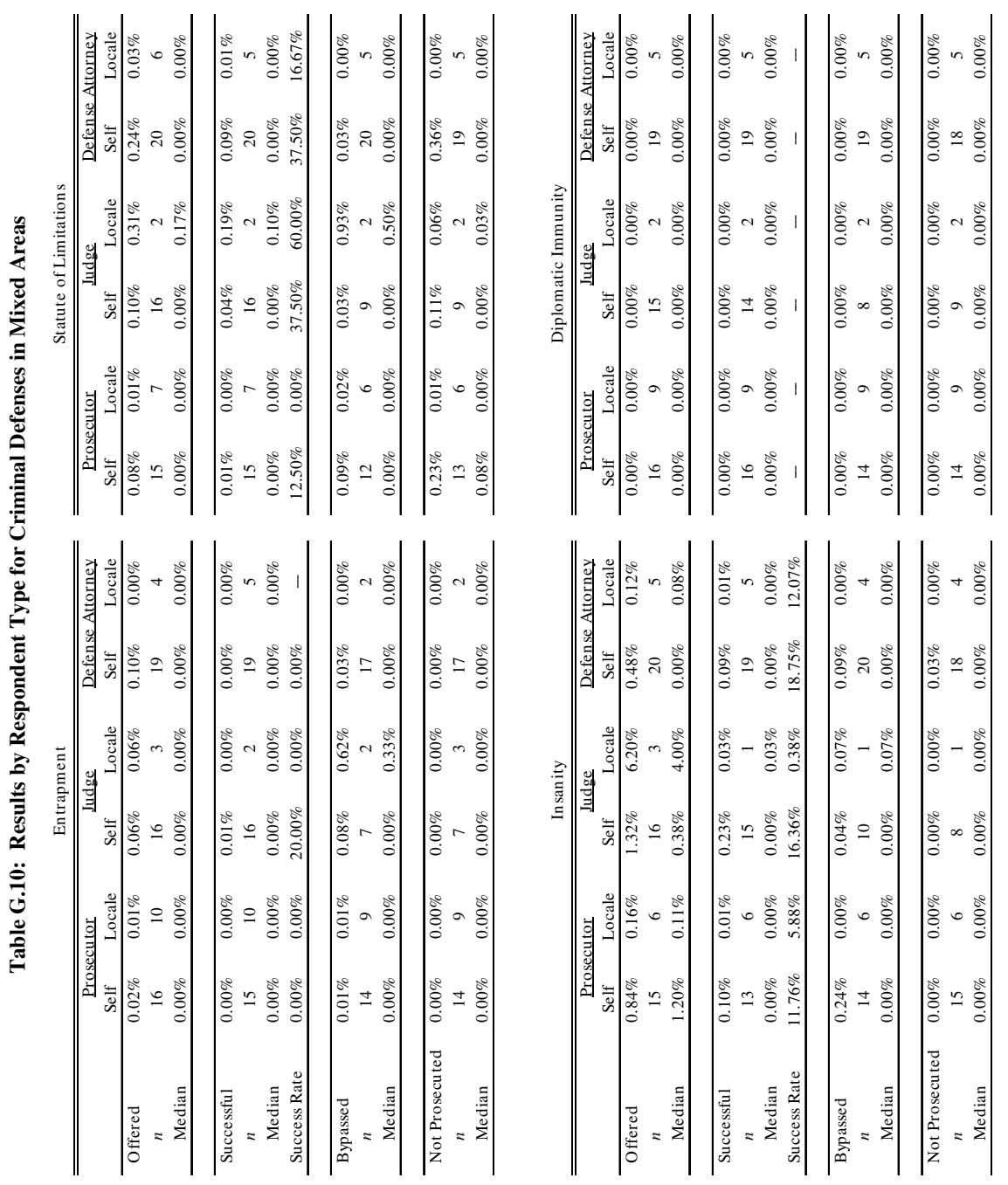




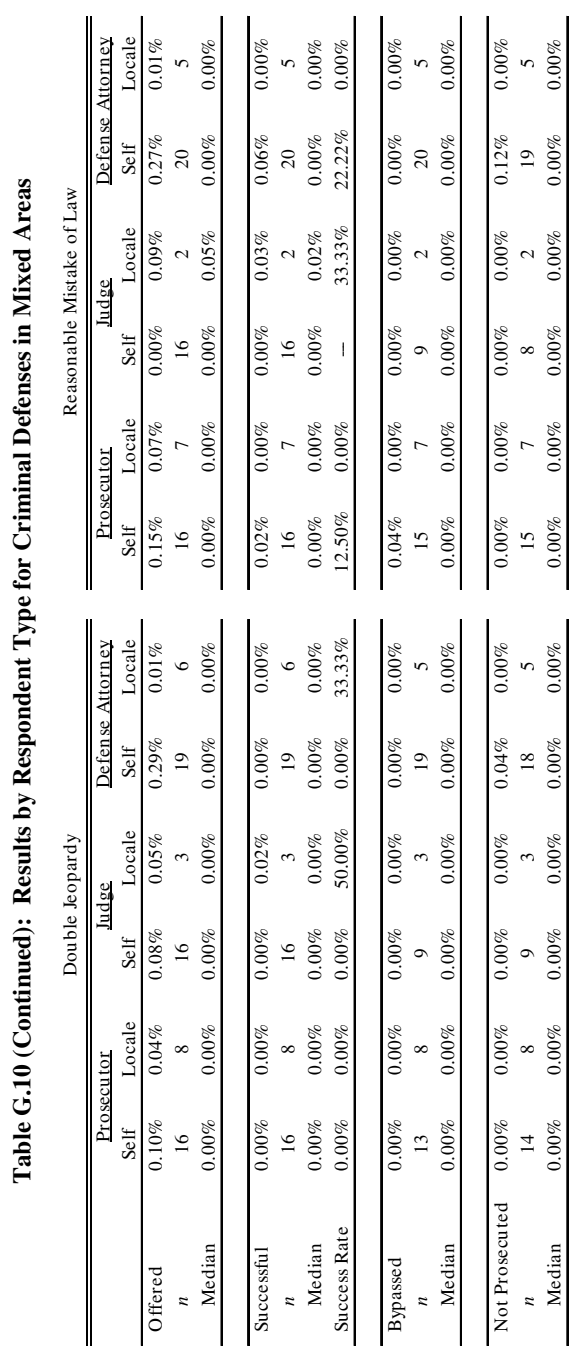




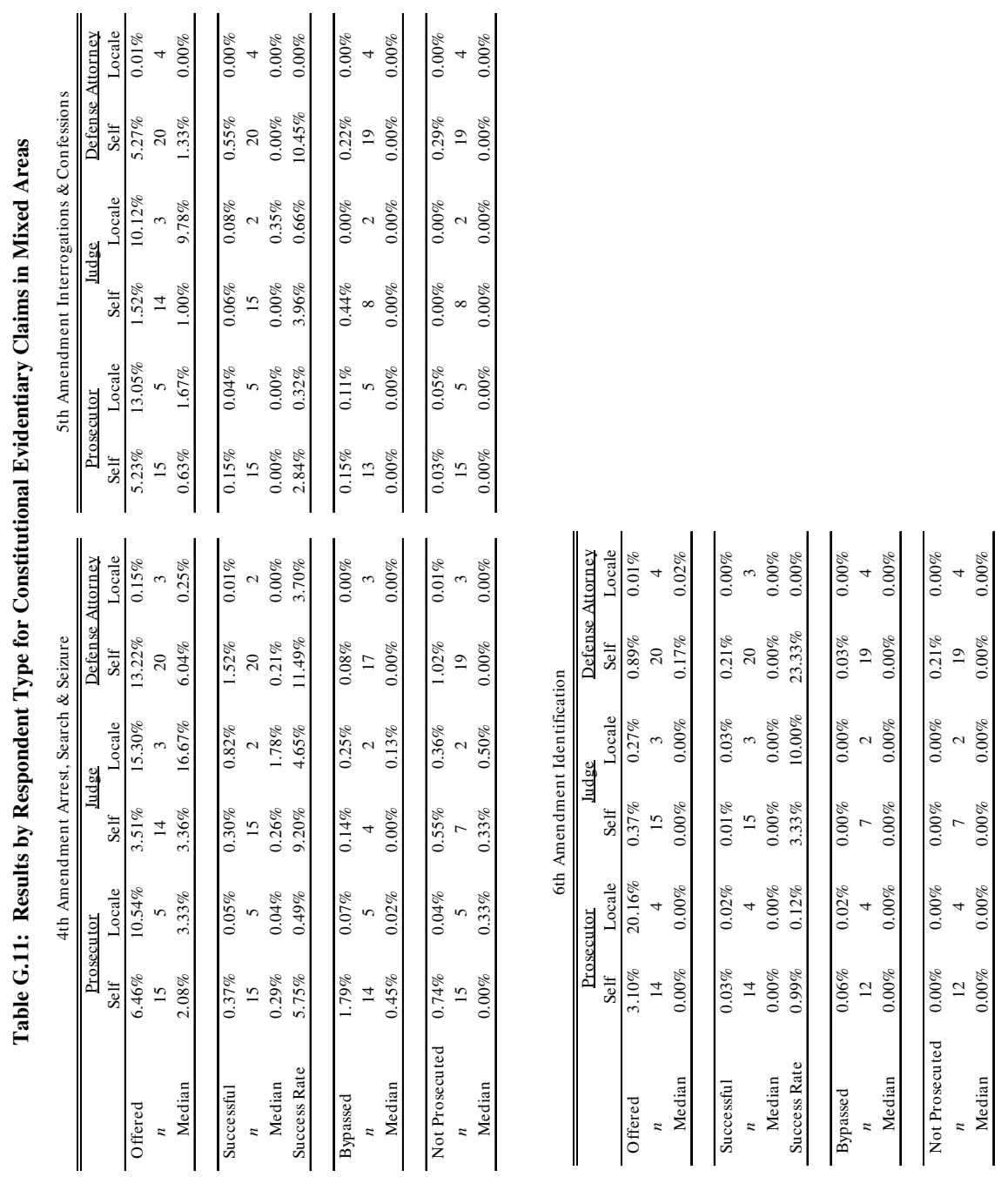




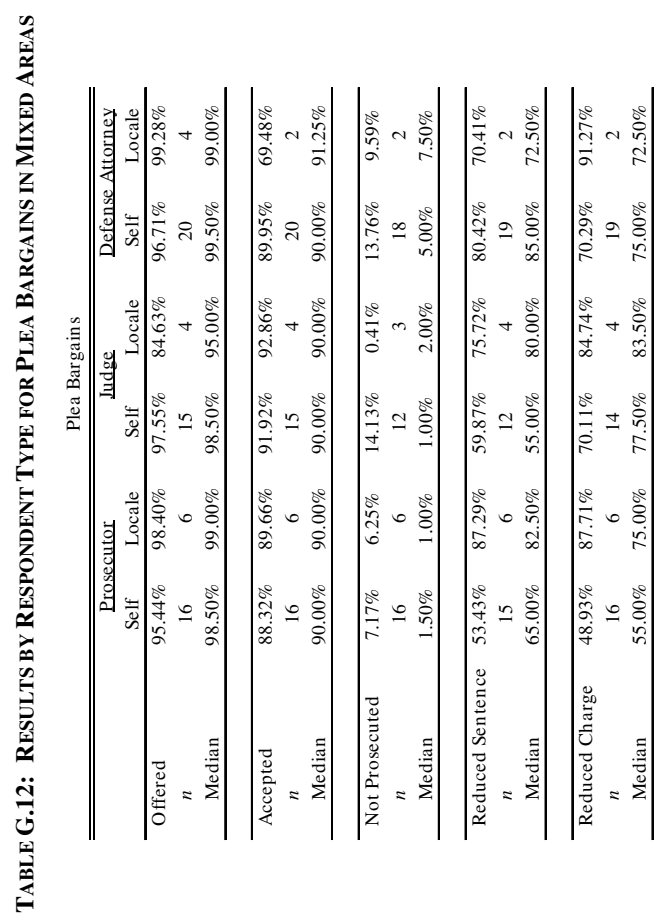

